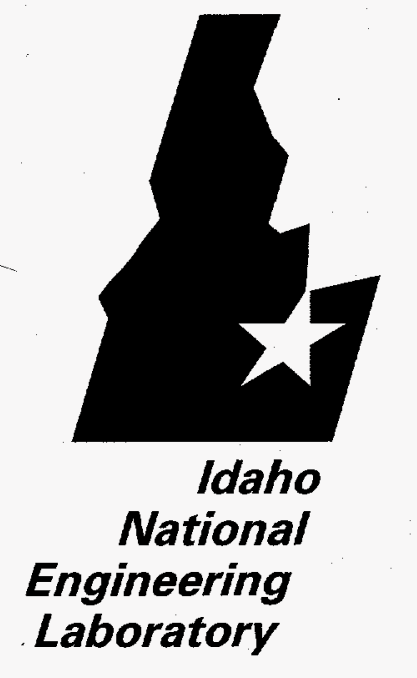

INEL-96/0330

December 1996

Proposed Research and Development Plan for Mixed Low-Level Waste Forms

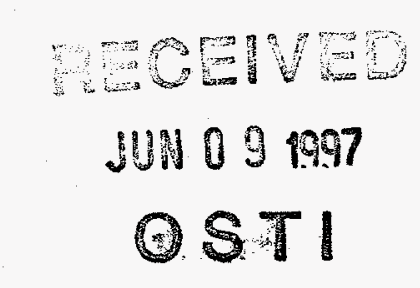

T. O'Holleran

$X$. Feng

P. Kalb

I. Pegg

B. Scheetz

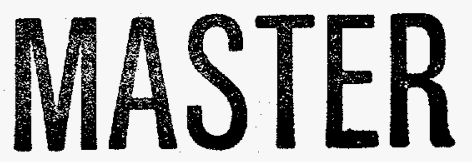

LOCKHEED MARTIN 


\title{
Proposed Research and Development Plan for Mixed Low-Level Waste Forms
}

\author{
T. O'Holleran \\ $X$. Feng \\ P. Kalb \\ I. Pegg \\ B. Scheetz
}

Published December 1996

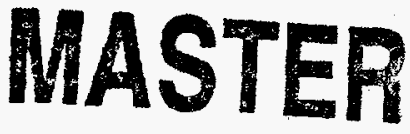

Idaho National Engineering Laboratory

Waste Management Technologies Department

Lockheed Martin Idaho Technologies Company

Idaho Falls, Idaho 83415

DISTRIBUTION OF THIS DOCUMENT IS UNLIMITED

Prepared for the

U.S. Department of Energy

Assistant Secretary for Environmental Management

Under DOE Idaho Operations Office

Contract DE-AC07-94ID13223 


\section{DISCLAIMER}

Portions of this document may be illegible in electronic image products. Images are produced from the best available original document. 


\section{DISCLAIMER}

This report was prepared as an account of work sponsored by an agency of the United States Government. Neither the United States Government nor any agency thereof, nor any of their employees, make any warranty, express or implied, or assumes any legal liability or responsibility for the accuracy, completeness, or usefulness of any information, apparatus, product, or process disclosed, or represents that its use would not infringe privately owned rights. Reference herein to any specific commercial product, process, or service by trade name, trademark, manufacturer, or otherwise does not necessarily constitute or imply its endorsement, recommendation, or favoring by the United States Government or any agency thereof. The views and opinions of authors expressed herein do not necessarily state or reflect those of the United States Government or any agency thereof. 


\section{ABSTRACT}

The objective of this report is to recommend a waste form program plan that addresses waste form issues for mixed low-level waste (MLLW). The report compares the suitability of proposed waste forms for immobilizing MLLW in preparation for permanent near-surface disposal and relates them to their impact on the U.S. Department of Energy's mixed waste mission. Waste forms are classified into four categories: high-temperature waste forms, hydraulic cements, encapsulants, and specialty waste forms. Waste forms are evaluated concerning their ability to immobilize MLLW under certain test conditions established by regulatory agencies and research institutions. The tests focused mainly on leach rate and compressive strength. Results indicate that all of the waste forms considered can be tailored to give satisfactory performance immobilizing large fractions of the Department's MLLW inventory. Final waste form selection will ultimately be determined by the interaction of other, often nontechnical factors, such as economics and politics. As a result of this report, three top-level programmatic needs have been identified: (1) a basic set of requirements for waste package performance and disposal; (2) standardized tests for determining waste form performance and suitability for disposal; and (3) engineering experience operating production-scale treatment and disposal systems for MLLW. 


\section{CONTENTS}

ABSTRACT $\ldots \ldots \ldots \ldots \ldots \ldots \ldots \ldots \ldots \ldots \ldots \ldots \ldots \ldots \ldots \ldots \ldots \ldots \ldots \ldots \ldots \ldots \ldots \ldots \ldots \ldots$

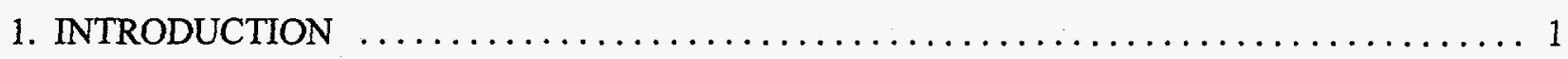

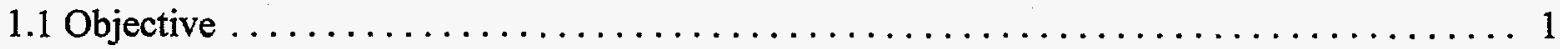

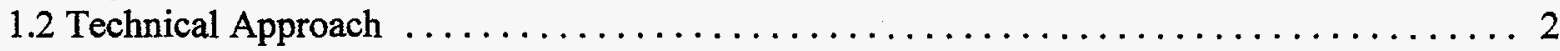

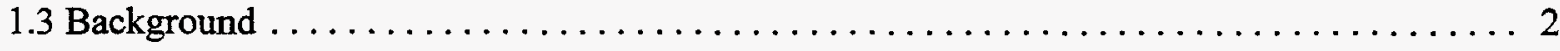

2. GENERAL RECOMMENDATIONS $\ldots \ldots \ldots \ldots \ldots \ldots \ldots \ldots \ldots \ldots \ldots \ldots \ldots \ldots \ldots$

2.1 Generic Performance Guidelines . . . . . . . . . . . . . . . . . . . . . 6

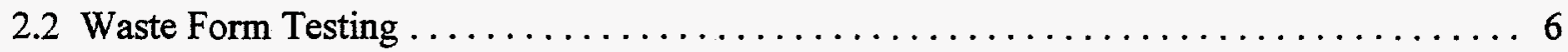

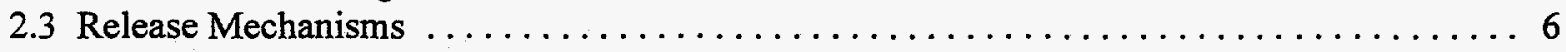

2.4 Research and Development Funding Criteria $\ldots \ldots \ldots \ldots \ldots \ldots \ldots \ldots \ldots \ldots \ldots \ldots \ldots \ldots \ldots \ldots \ldots$

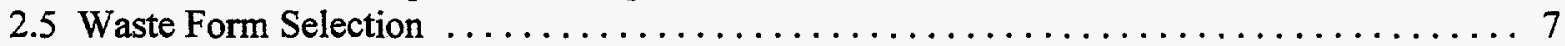

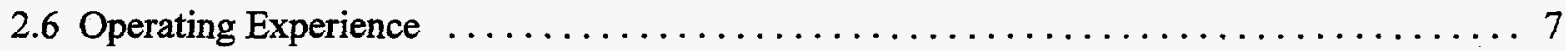

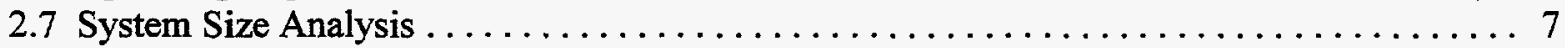

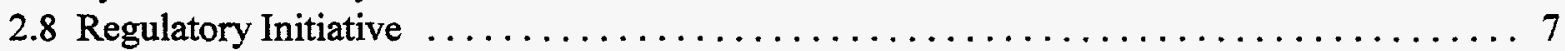

3. SPECIFIC RECOMMENDATIONS $\ldots \ldots \ldots \ldots \ldots \ldots \ldots \ldots \ldots \ldots \ldots \ldots \ldots$

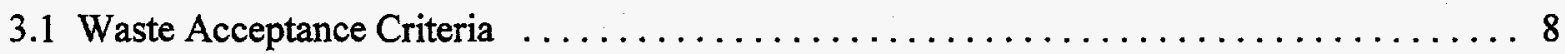

3.2 Release of Radionuclides and Hazardous Constituents from Waste Forms $\ldots \ldots \ldots \ldots .8$

3.3 Data for Directly Comparing the Performance of All Waste Forms . . . . . . . . . . 9

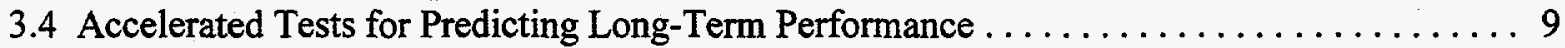

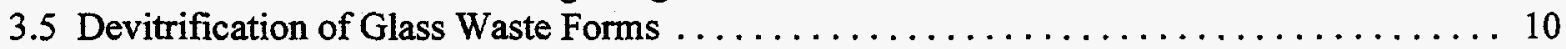

3.6 Disposed Waste Volume Reduction using "Hybrid" Waste Forms . . . . . . . . . . 11

3.7 Suitability of High-Temperature Waste Forms for Immobilizing Volatile Elements . . . . . 11

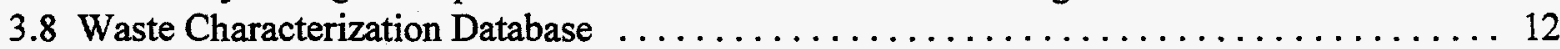

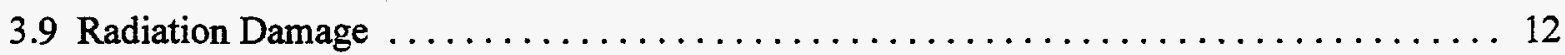

3.10 Natural/Anthropogenic Analogues for Verifying Predictions of

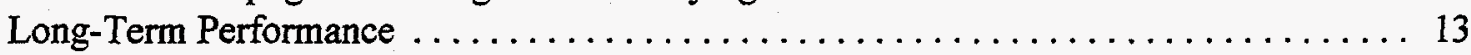

3.11 Recommendations for Specific Waste Forms $\ldots \ldots \ldots \ldots \ldots \ldots \ldots \ldots \ldots \ldots \ldots \ldots \ldots$

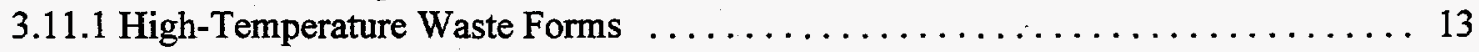

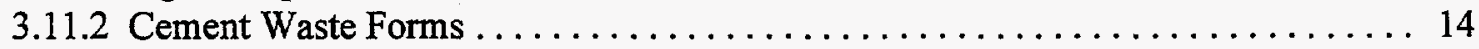

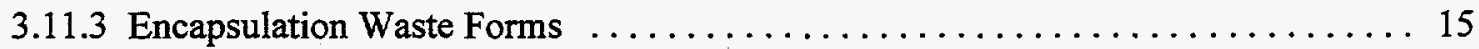

4. RECOMMENDED R\&D PROGRAM $\ldots \ldots \ldots \ldots \ldots \ldots \ldots \ldots \ldots \ldots \ldots \ldots \ldots \ldots \ldots$

Appendix A-Supporting Information for the Proposed Research and Development Plan for Mixed Low-

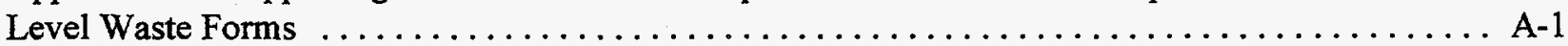

\section{Figures}

1. Factors influencing appropriateness of waste form $\ldots \ldots \ldots \ldots \ldots \ldots \ldots \ldots \ldots \ldots$

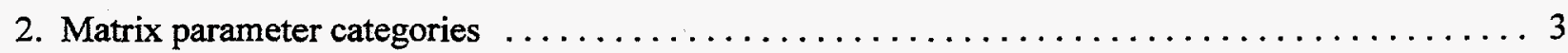

3. Graphical representation of MLLW inventory data classified by top-level MPC $\ldots \ldots \ldots \ldots$ 
4. Schematic diagram showing the logical relationships between top-level activities and decision milestones for the recommended R\&D program

5. Gantt chart showing estimated schedule relationships between the activities and decision milestones shown in Figure 4

\section{Tables}

1. MLLW inventory by top-level MPC categories. 


\section{Proposed Research and Development Plan For Mixed Low-Level Waste Forms}

\section{INTRODUCTION}

\subsection{Objective}

The objective of the U.S. Department of Energy's (DOE's) Waste Form Task for FY 1996 is to recommend a waste form program plan that addresses waste form issues for mixed low-level waste (MLLW) from a systems perspective. The approach involves analyzing waste form issues and their interrelationships, comparing methods used to measure waste form performance with performance assessment/evaluation and regulatory needs, summarizing existing waste form information, identifying issues and requirements that are not being adequately addressed, and formulating a draft program plan to address the identified inadequacies. Diverse technical, legal, and political issues were incorporated into the analysis. Various waste form materials and geometries were considered, including potential hybrid waste forms (e.g., a vitrified waste form encapsulated in a salt-bearing polymer). The task integrated all related issues to address the fundamental question "How good is good enough?" for safe and costeffective disposal of mixed and low-level waste (see Figure 1).

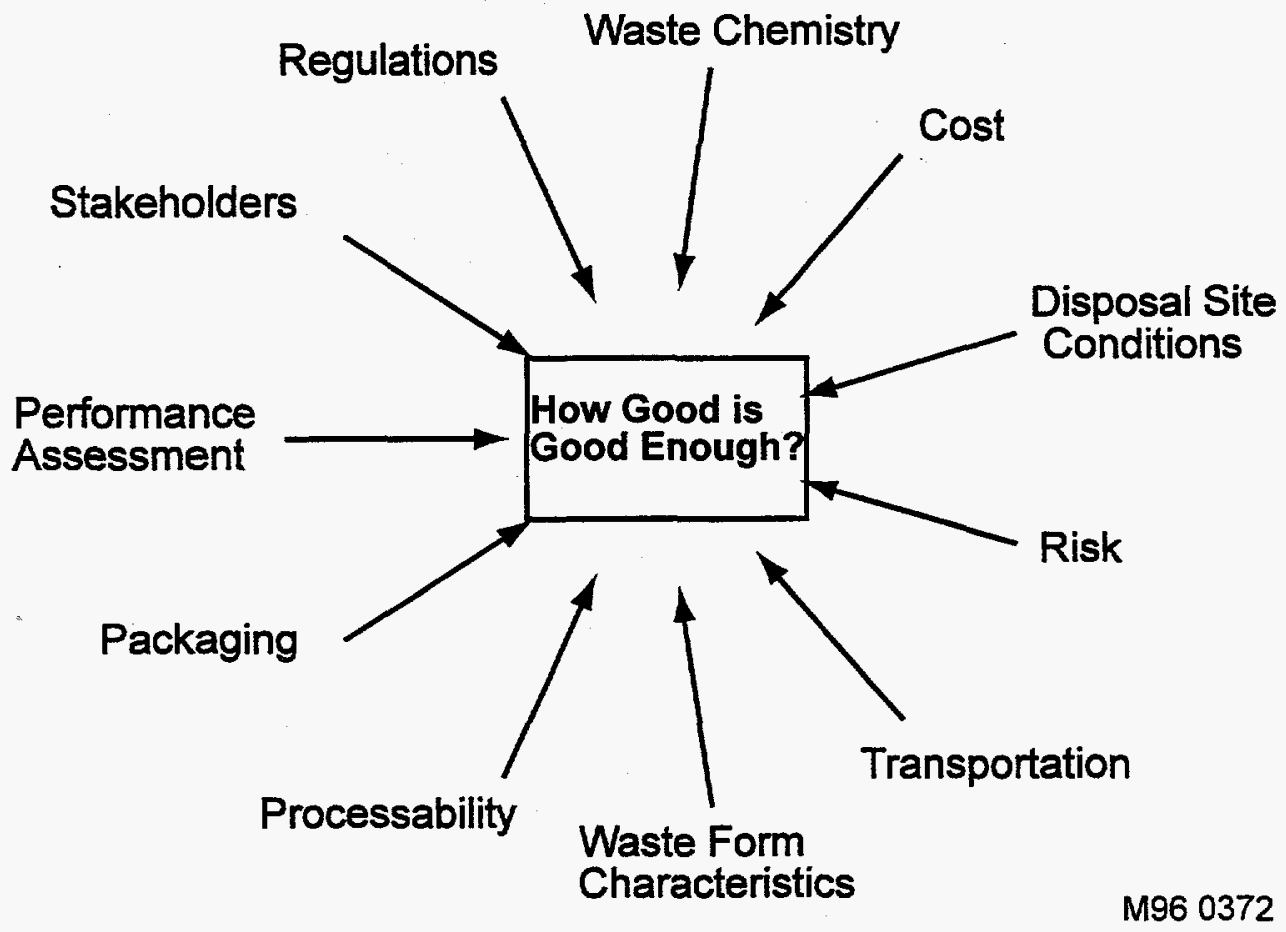

Figure 1. Factors influencing appropriateness of waste form. 


\subsection{Technical Approach}

Programmatic research and development (R\&D) needs were derived from technical deficiencies that experts identified during evaluation of candidate waste forms and related issues. A waste form program plan is proposed to address these needs. The program is described in terms of top-level R\&D activities, with an endpoint defined as startup of a treatment system (or systems) that would prepare MLLW for disposal. Logical relationships between the proposed activities have been developed, along with an estimated schedule. Development of the schedule assumed adequate and consistent funding for the program. The program plan constitutes the main body of this report. The background information that was used to develop the plan is presented in Appendix A.

\subsection{Background}

The problem of disposing of MLLW can be put in perspective by examining a breakdown of the MLLW inventory by what is obtusely referred to as "Matrix Parameter Categories" (MPCs). These MPCs give a gross indication of the chemical and physical makeup of the inventory. Figure 2 is a chart showing a hierarchical breakdown of MPCs. 


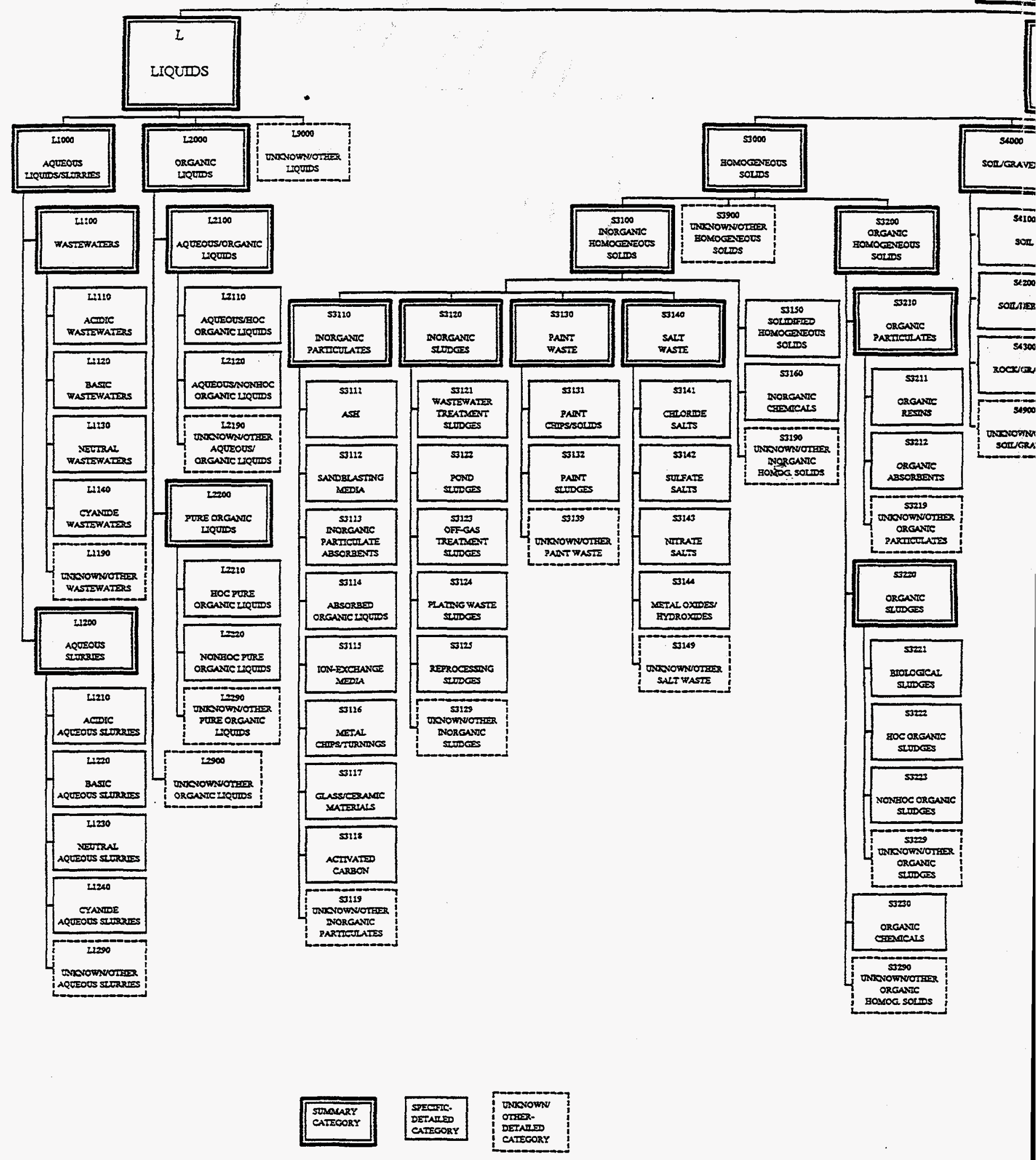


When combined with inventory data, the MPCs define (albeit grossly) the major waste streams that must be treated for disposal. Table 1 shows the Department's MLLW inventory broken out by top-level MPC categories.

Table 1. MLLW inventory by top-level MPC categories. MPC categories are listed in the form "An***", where $\mathrm{A}$ is a letter, $\mathrm{n}$ is a number, and the *s indicate a roll-up of all categories below An000 in the hierarchy. These data were derived from a comparison of the 1995 Mixed Waste Inventory Report (MWIR) and inventories reported in Site Treatment Plans (STPs).

\begin{tabular}{|c|c|c|c|}
\hline MPC Codes & Description & $\begin{array}{c}\text { From STP/MWIR } \\
\text { (1995) Cross-Walk } \\
\text { (cubic meters) }\end{array}$ & $\%$ of total \\
\hline$\overline{\mathrm{L} 1 * * *}$ & Aqueous Liquids/Slurries & 5,342 & $4.6 \%$ \\
\hline $\mathrm{L} 2 * * *$ & Organic Liquids & 2,166 & $1.9 \%$ \\
\hline $\mathrm{L} 9 * * *$ & Unknown/Other Liquids & 5 & $0.0 \%$ \\
\hline $\mathrm{S} 3 * * *$ & Homogeneous Solids & 58,007 & $50.2 \%$ \\
\hline$S 4 * * *$ & Soil/Gravel & 12,900 & $11.2 \%$ \\
\hline $\mathrm{S} 5 * * *$ & Debris & 34,419 & $29.8 \%$ \\
\hline $59 * * *$ & Unknown/Other Solids & 66 & $0.1 \%$ \\
\hline U9*** & Unknown/Other Matrix & 491 & $0.4 \%$ \\
\hline$X 6^{* * *}$ & Lab Packs & 479 & $0.4 \%$ \\
\hline \multirow[t]{2}{*}{$\mathrm{X} 7 * * *$} & Special & 1,602 & $1.4 \%$ \\
\hline & TOTAL MLLW & 115,477 & \\
\hline
\end{tabular}

The data from Table 1 is also shown graphically in Figure 3.

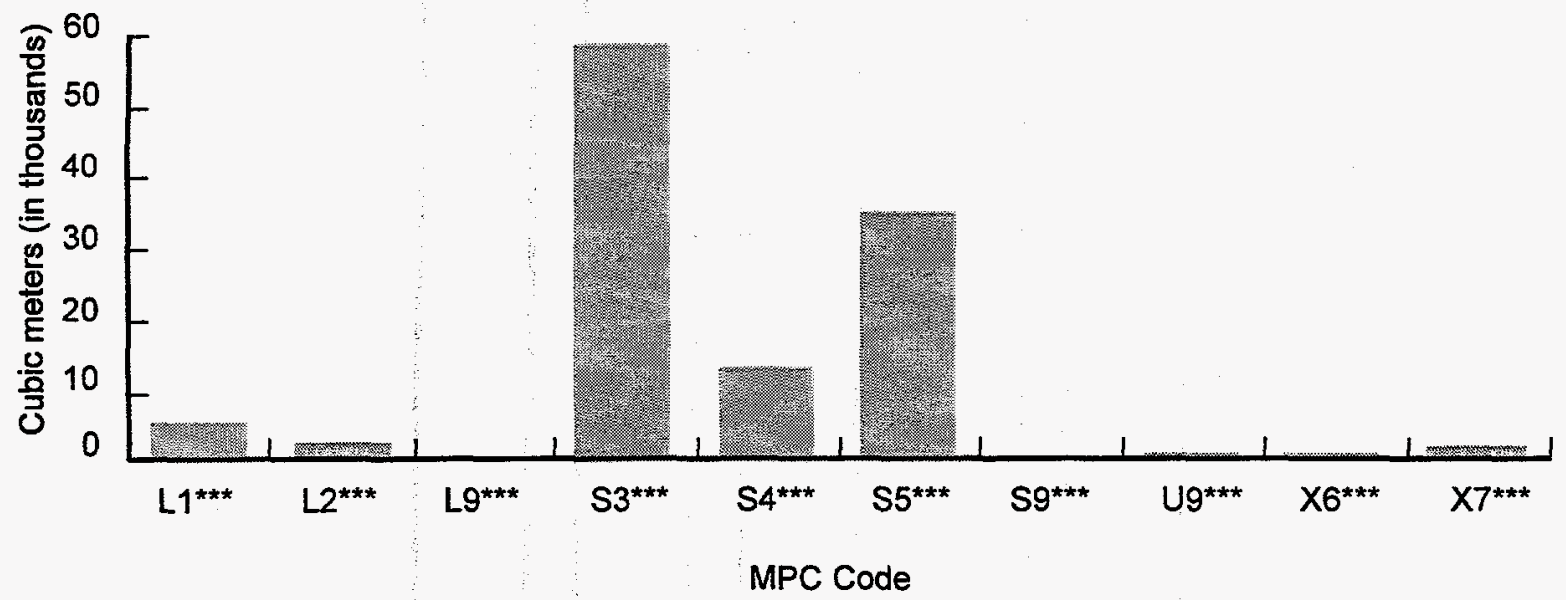

Figure 3. Graphical representation of MLLW inventory data classified by top-level MPC.

As can be seen from Table 1 and Figure 3, over 90\% of the Department's MLLW inventory resides in MPCs S3***, S4***, and S5***. Therefore, the recommendations in this volume are specifically directed at the treatment and disposal of wastes in these categories. Because of the large volumes 
involved, the Department is expected to benefit the most from programmatic efforts directed at these waste streams.

Programmatic needs have been identified that have a significant influence on MLLW treatment and disposal. Recommendations for establishing requirements for disposal of treated and stabilized MLLW were formulated based on those needs. The three top-level (programmatic) needs identified are:

1. A basic set of requirements for waste package performance and disposal

2. Standardized tests for determining waste form performance and suitability for disposal (in part related to 1 above)

3. Engineering experience operating production-scale treatment and disposal systems for MLLW.

The first need, and, to an extent, the second need are directly reflected in the question, "How good is good enough?" Addressing the first need provides a direct answer to the question, "How good is good enough?" However, the second need makes it difficult to answer the follow-on question, "Is this waste form good enough?" Without addressing the first two needs, resources cannot be effectively focused on the ultimate goal of disposing of MLLW. Furthermore, stakeholder buy-in will be very difficult to attain while these needs exist.

The third need goes beyond "How good is good enough?" to "How do I do it?" While economy of scale may make very large facilities economically attractive, the technical risk of building and operating such a facility without solid engineering and operational experience at smaller scales is high. Lack of operational experience makes strategic decisions much more difficult, exacerbates design problems for very large facilities, and reduces stakeholder confidence in the operation.

Stakeholder buy-in presents a dilemma, because not all stakeholders view progress towards the goal of disposing of MLLW as desirable. Despite its technical components, this issue must ultimately be resolved in the political arena. A necessary but difficult step in the process is to clearly and honestly define the objectives and agendas of each of the individual stakeholder groups. Only then can debate and the art of compromise be expected to achieve any real progress. 


\section{GENERAL RECOMMENDATIONS}

\subsection{Generic Performance Guidelines}

- Develop generic (minimum) waste form performance guidelines that ensure the ability to dispose of waste at virtually any site.

- Use performance evaluation methodology to develop a basis for generic waste form performance guidelines.

\subsection{Waste Form Testing}

Improve the waste form characterization database, including, but not limited to:

- Developing or improving accelerated performance tests as appropriate for candidate waste forms.

- Standardizing existing data to a common basis for reporting release data so that waste forms can be compared directly.

\subsection{Release Mechanisms}

Improve understanding of waste form release mechanisms, including, but not limited to:

- Improving understanding of radiation damage effects. Our understanding of radiation damage is more detailed for some waste forms than for others. This will necessarily be a long-term effort, and so should be started as soon as possible. Annual funding allocations need not be large, but a long-term funding commitment is needed.

- Searching for natural/anthropogenic analogues with long-term environmental exposure. This activity should initially be limited to an exploratory effort to identify candidate analogues and assess their relevance to verifying predictions of long-term waste form behavior. Only candidates identified as useful in the initial exploratory effort should be investigated further in a second-phase effort.

\subsection{Research and Development Funding Criteria}

Develop evaluation criteria for assessing existing and proposed $R \& D$ projects that will focus resources on achieving near-term progress on waste treatment from existing data and technologies. Applied R\&D projects that offer near-term payoffs in terms of actually treating waste should receive funding priority. Basic $R \& D$ that promises payoffs in the long-term should receive lower priority at this time. 


\subsection{Waste Form Selection}

Evaluate existing waste forms and associated production processes against waste inventories to determine which waste forms require further development and which are candidates for treatability studies. Restrict introduction of new waste forms, since most existing waste forms can give satisfactory performance when used to immobilize most of the Department's waste. Continued development of waste forms should be justified in terms of potential technical benefits or cost savings. For example, continued development of existing waste forms is desirable where necessary to improve confidence when assessing applicability to various waste streams. Evaluating potential benefits of "hybrid" combinations of existing waste forms is desirable where potential for volume reduction or other benefits exist. Developing new applications for existing waste forms to allow existing technologies to treat more waste streams is also desirable.

\subsection{Operating Experience}

Build and operate a few small to moderate-size facilities based on current technologies to gain engineering experience treating various types of MLLW.

\subsection{System Size Analysis}

Perform a systems analysis to determine the optimum size for treatment facilities. The analysis should take into account political, stakeholder, and transportation factors, as well as the geographic distribution of the MLLW inventory and candidate locations for disposal sites.

\subsection{Regulatory Initiative}

Pursue inclusion of all advanced waste forms under the proposed Hazard Waste Identification Rule. This would provide for delisting of hazardous wastes under a more relaxed regulatory framework, and allow economic competition between waste forms. 


\section{SPECIFIC RECOMMENDATIONS}

\subsection{Waste Acceptance Criteria}

Disposal sites will develop site-specific Waste Acceptance Criteria (WAC) based on site-specific performance assessments. However, the current lack of WAC impedes the selection of treatment technologies and the subsequent design and construction of treatment facilities. To eliminate this impediment, a generic WAC is needed that would ensure the acceptance of any waste form produced to meet that WAC at any credible disposal facility.

\section{Recommendation:}

Issue generic WAC based on performance assessment results from a hypothetical disposal site with aggressive conditions for waste form alteration. The performance assessment should provide maximum allowable release rates for radionuclides and hazardous constituents of concern. These release rates would be "limiting" in the sense that any waste form that falls below these limits would be disposable at virtually any site. This information, along with regulatory requirements, would be used by waste form producers to develop product specifications for the waste form(s) they will fabricate.

\subsection{Release of Radionuclides and Hazardous Constituents from Waste Forms}

The mechanisms by which radioactive and hazardous components are released from waste forms are not always well understood for all candidate waste forms. This leads to difficulties developing and interpreting results from accelerated tests, calculating releases for performance assessments, and designing and interpreting radiation damage experiments. It also severely limits the relevance of process studies that define acceptable limits for operational variables. Such studies are essential for defining the process and ensuring production of acceptable waste forms, but cannot be applied to real waste treatment problems without clearer definition of waste stream make-up.

\section{Recommendation:}

Release mechanisms for borosilicate glass are better understood than for other waste forms, but less has been done to evaluate this material for immobilization of MLLW. Furthermore, most of the research into release mechanisms has addressed release of radionuclides. Very little is known about release of hazardous constituents. Initiate an experimental program to elucidate radioactive and hazardous component release mechanisms for candidate waste forms for which release mechanisms are not clearly understood. The program should focus on:

1. Identifying release mechanisms, especially for hazardous components,

2. Quantifying release rates

3. Quantifying the effects of environmental (and performance test) conditions on release mechanisms and rates.

The objective should be to advance the state of understanding of release mechanisms for hazardous and radioactive components for all candidate waste forms to a level approaching the current level of understanding of radioactive release mechanisms for borosilicate glass. 


\subsection{Data for Directly Comparing the Performance of All Waste Forms}

A variety of tests have been used to generate performance data, particularly release (leach) data, on waste forms. However, because of the variety of test procedures and methods for analyzing the raw data, the reported results often do not permit direct comparisons of waste forms.

\section{Recommendation:}

Analyze the test methods used to generate existing data on waste form release performance, and reformulate the results to build a unified data base of waste form release data based on a common system of units to allow direct comparisons of waste form performance and waste form release rates used in performance assessments. It may be necessary to devise and perform additional tests if difficulties are encountered during this effort.

\subsection{Accelerated Tests for Predicting Long-Term Performance}

Reliable testing methods are needed for predicting the radioactive and hazardous element release rates of waste forms when exposed to anticipated disposal site conditions for extended periods of time. Such an extrapolation will require a detailed understanding of waste form alteration mechanisms, and will therefore require development of tests that are tailored to specific waste forms. Test results and extrapolations should be validated by comparisons to observed behavior of natural/anthropogenic analogues. Such tests would enhance the accuracy of performance assessment results, as well as public confidence in predictions of disposal system performance.

\section{Recommendation:}

Develop and validate accelerated test methods for predicting long-term performance of waste form(s) selected for waste immobilization. Four tasks are recommended to accomplish this objective:

1. Because development of reliable accelerated tests will require considerable effort, a systems analysis should be performed first to reduce the number of primary and secondary waste forms for which tests are developed

2. Determine relevant waste form alteration mechanisms

3. Develop appropriate test methods

4. Compare results and predicted performance to natural/anthropogenic analogues.

Closure of this activity should be accomplished by technical peer review of the results, and formalizing the test methods as standard procedures. 


\subsection{Devitrification of Glass Waste Forms}

Glass waste forms can devitrify (crystallize) if held at sufficiently high temperatures for sufficiently long periods of time. This phenomenon can occur if the glass is reheated after solidification, or if the molten glass is cooled too slowly. When glass devitrifies, radionuclides and hazardous constituents can be partitioned into the various phases that form. Depending on the characteristics of the phases that form and the radionuclides and hazardous constituents that each phase hosts, the overall release behavior of the waste form can be enhanced or degraded, sometimes by orders of magnitude. Because of the low thermal conductivity of most silicate melts, the physical dimensions of the container into which molten waste glass is poured can strongly influence cooling rates, especially near the center of the glass. For example, the privatization Request for Proposals for Hanford LLW waste specifies that the LLW products be packaged in a rectangular metal container $1.8 \mathrm{~m}$ long $\times 1.2 \mathrm{~m}$ wide $\times 1.2 \mathrm{~m}$ high. If poured into such a container as a monolith, glass at the center of the container could remain above the glass transition temperature ( $\mathrm{Tg}$ ) for up to one week if the container is cooled in ambient air. Such a prolonged cool-down would likely result in considerable devitrification. Furthermore, such large glass pours invariably crack during cool-down, resulting in an increase in surface area that can further increase release rates. One study on high-level waste (HLW) glass at Pacific Northwest National Laboratory suggests that a heat treatment on an $\mathrm{HLW}$ glass for 25 hours following a canister centerline cooling schedule resulted in the development of 50 vol.\% crystals in the glass, resulting in an increase in chromium and boron release rates up to a factor of 200. If this is the case for MLLW glass, and compelling reasons exist to use a container of this type, the glass may have to be formed as small rapidly quenched drops ("gems") to control devitrification.

\section{Recommendation:}

Initiate a program to quantify the devitrification and cracking phenomena in LLW glass production and its effects on glass durability and other properties. Develop quantitative models for the prediction of crystallization under glass cooling conditions. This program may include, but need not be limited to, the following tasks:

1. Develop glass cooling schedule.

2. Characterize glass crystallization kinetics.

3. Generate data on glass composition effects on crystallization.

4. Develop models for predicting devitrification and cracking behavior according to glass composition and cooling schedule.

5. Quantify the release behavior of the bulk devitrified glass and the various phases resulting from devitrification.

6. Develop models to predict the chemical durability of devitrified glasses.

7. Investigate glass/container interface reactions to assess potential effects on waste form performance. 


\subsection{Disposed Waste Volume Reduction using "Hybrid" Waste Forms}

Waste forms that leave an appreciable void fraction in packaging containers (such as glass "gems" or briquetted wastes) result in larger waste volumes going to disposal than necessary. If another waste stream, such as a secondary waste stream, is also present, and is stabilized in a form that could be used to fill the voids in the primary waste form container, significant savings in disposal costs could be realized.

\section{Recommendation:}

Perform a systems analysis to identify potential treatment processes that could benefit from a hybridized waste form, and calculate the cost drivers. If the system and cost analyses are favorable, evaluate the performance characteristics of the candidate hybrid waste form. It will likely be necessary to develop special testing protocols to measure performance of such a waste form.

\subsection{Suitability of High-Temperature Waste Forms for Immobilizing Volatile Elements}

High-temperature waste forms offer distinct advantages in terms of destruction of certain hazardous constituents and can deliver exceptional waste form performance. The performance of good high-temperature waste forms so far exceeds any anticipated acceptance criteria that acceptance of these materials at any disposal site is virtually assured. For these reasons, the proposed Hazardous Waste Identification Rule would delist hazardous waste treated by vitrification. However, immobilizing waste streams with significant quantities of volatile components can be problematic. The high temperatures required drive volatile elements out of the main treatment process. The volatile components are usually either separated before the high-temperature operation, or captured in the off-gas. A secondary (low-temperature) waste form is usually required to immobilize the separated volatiles. The secondary waste form increases the volume of waste requiring disposal, and increases the complexity of the overall treatment process.

A few "low-temperature" glasses exist that significantly reduce losses by volatilization. Borosilicate glass was developed for immobilizing $\mathrm{HLW}$ with significant quantities of volatile radionuclides $\left({ }^{137} \mathrm{Cs}\right)$. However, little information is available on application of this waste form to MLLW immobilization.

A few high-temperature processes that use closed containers have been investigated for immobilizing HLW and transuranics. These include hot uniaxial pressing (HUP) and hot isostatic pressing (HIP). Both processes apply heat and pressure to waste and additives sealed in a canister. The HUP process uses a ram to apply pressure in a uniaxial direction. The HIP process uses gas pressure to apply isostatic pressure. In both cases, volatile elements are contained within the canister.

\section{Recommendation:}

Evaluate the use of low-temperature glasses for immobilizing waste containing volatile components. The objective is to determine whether low-temperature vitrification processes can reduce the functional requirements of the off-gas system enough to significantly reduce overall system cost. Advanced low-temperature glass-forming techniques such as those using chemically-derived precursors should also be included. Additives used in these methods are generally more costly, and the process more complex, so it is anticipated that these methods would be most attractive for small volume secondary waste streams that are difficult to process by other means. 
Evaluate HIP and HUP for immobilizing waste streams with volatile elements in high-temperature waste forms. The evaluation should include laboratory-scale proof of principle tests of candidate waste formulations and process parameters, as well as cost and risk comparisons with more conventional systems.

\subsection{Waste Characterization Database}

The characteristics of existing waste are known in a general sense (see Figure 1), but specific information that is needed to develop process control strategies is lacking. For example, lack of information regarding the expected chemical and physical fluctuations of the waste stream coming into a treatment process makes it very difficult to establish control limits and anticipate process upsets. Improved waste stream characterization data will not only benefit the development and selection of treatment technologies, but will also reduce the requirements for pretreatment characterization for those treatment technologies that are implemented.

\section{Recommendation:}

Initiate an effort to collect data to define the chemical and physical variability of existing waste. The effort should consist of two tasks:

1. Begin collecting data immediately by the most expeditious means currently available at the sites where the waste is stored

2. Develop invasive and noninvasive technologies, as appropriate, to rapidly and inexpensively assay the contents of waste containers.

The objective is to obtain a quantitative estimate of the physical and chemical variability in the inventory so that process designers can estimate feed stream variability as a function of time and design head-end pretreatment operations. Detailed characterization is beyond the scope of this task.

\subsection{Radiation Damage}

Accumulated radiation damage may significantly affect long-term waste form performance. However, for many candidate waste forms, insufficient data exists to determine whether long-term performance will be degraded as radiation damage accumulates. Information is needed concerning radiation damage mechanisms, potential damage repair mechanisms (if any), damage accumulation rates, and relation of accumulated damage to waste form performance. This information would enhance confidence in performance assessment results by improving predictions of long-term performance.

\section{Recommendation:}

Initiate a program to quantify radiation damage effects in selected waste forms. Because of the effort involved, the waste forms to be considered in this program should be selected by a systems analysis for implementation in waste treatment systems. This program should consist of the following activities:

1. Identify radiation damage mechanisms, and repair mechanisms, if applicable

2. Develop accelerated radiation damage tests 
3. Quantify radiation damage effects on waste form performance.

Note that the relative importance of this task depends on the "period of regulatory concern." In most MLLW forms, radiation damage will accumulate slowly, so the shorter the period of regulatory concern, the less important this task is. The U.S. Nuclear Regulatory Commission (NRC) plans to address this issue some time in the near future. Defer significant spending on this task until the NRC's position becomes clear.

\subsection{Natural/Anthropogenic Analogues for Verifying Predictions of Long-Term Performance}

Confidence in long-term predictions of waste form performance can be significantly enhanced by studies of similar materials that have been exposed to naturally-occurring conditions for extended periods of time. Such materials are called analogues, and some data on natural and anthropogenic analogues exist for glasses, some crystalline waste form phases, and cements. However, similar data is lacking for other candidate waste forms. Such data would enhance confidence $n$ volt) maximum energy beta particle ( $\beta^{-}$, a negative electron emitted from the nucleus), with no accompanying gamma-ray. After decaying to yttrium, the ${ }^{90} \mathrm{Y}$ nucleus usually decays $\left(T_{1 / 2} \approx 64\right.$ hours) to in long-term performance predictions and hence performance assessment results, and can be particularly effective in building stakeholder confidence.

\section{Recommendation:}

Initiate a program to identify natural/anthropogenic analogues, and relate natural conditions and observed effects on analogues to waste forms and long-term performance predictions.

\subsection{Recommendations for Specific Waste Forms}

\subsubsection{High-Temperature Waste Forms}

High-temperature waste forms offer distinct advantages in terms of volume reduction and waste form performance. The performance of high-temperature waste forms so far exceeds any anticipated acceptance criteria that acceptance of these materials at any disposal site is virtually assured. However, immobilizing waste streams with significant quantities of volatile components can be problematic. The high temperatures required drive volatile elements out of the main treatment process. The volatile components are usually either separated before the high-temperature operation, or captured in the off-gas. A secondary (low-temperature) waste form is usually required to immobilize the separated volatiles. The secondary waste form increases the volume of waste requiring disposal, and increases the complexity of the overall treatment process.

A few high-temperature processes that use closed containers have been investigated for immobilizing HLW and transuranics. These include hot uniaxial pressing (HUP) and hot isostatic pressing (HIP). Both processes apply heat and pressure to waste and additives sealed in a canister. The HUP process uses a ram to apply pressure in a uniaxial direction. The HIP process uses gas pressure to apply isostatic pressure. In both cases, volatile elements are contained within the can.

Recommendations are as follows:

- Evaluate HIP and HUP for immobilizing waste streams with volatile elements in high-temperature waste forms. The evaluation should include laboratory-scale proof of 
principle tests of candidate waste formulations and process parameters, and cost and risk comparisons with more conventional systems.

- Evaluate addition of chopped fibers to improve immersion stability of hydraulic cements.

- Gather and study existing raw data on glass leaching to relate glass leach data to the leachability index defined in American National Standards Institute/Amercian Nuclear Society (ANSI/ANS) 16.1.

- Improve basic understanding of the development and degradation of cement properties. Studies of ancient cements should be encouraged.

- Develop short-term tests to predict long-term behavior of waste forms, particularly the low-temperature waste forms (cements, polymers, etc.).

- Evaluate radiation effects on leachability.

- Develop mechanistic release model for encapsulant-type waste forms.

- Correlate existing leach test data with performance under actual disposal site conditions.

\subsubsection{Cement Waste Forms}

\subsubsection{Process Issues}

Portland Cement. Processing of ordinary Portland cement (OPC) waste forms is a mature technology. However, the properties of OPC are process sensitive and require good quality control. At the present time, there are at least three different commercial technologies that appear to be suitable for the immobilization of MLLW. A good body of information exists on the design of cementitous Portland cement-based waste forms to enhance their performance via control over total porosity, and pore size distributions. This knowledge should be incorporated into the design of fundamental formulations, i.e., the use of slags for Eh and size distribution control.

Non-Portland Cement. Processing issues for non-Portland cement are of concern because there is little practical experience on the necessary scale. Those cement systems used in industrial construction applications are exceptions i.e., high alumina cement and Sorrel cements. Alkali-activated cement has different rheological behavior than does Portland cement. Alkali-activated cements are an emerging technology and must be carefully evaluated to adapt to full-scale production capabilities in order to fully exploit their advantages. For instance, controlling set time via an applied electrical field should be evaluated. The use of these cements to immobilize organic compounds needs to be systematically explored.

\subsubsection{Product Issues}

Portland Cement. Portland cement-based waste forms are the most widely used host matrices for hazardous and nuclear wastes world-wide. The basis for their use is a 170-year history of industrial usage presently amounting to hundreds of millions of tons annually: In the nuclear community, however, Portland cement has gained a negative reputation based upon several well-publicized and entirely preventable failures. As with any material, good quality control practices need to be established and followed to ensure that laboratory and pilot-scale products translate into full-scale products. Organic 
compounds in Portland cement have the potential for altering the setting behavior and physical properties of the final waste form. The nuclear community's use of organic compounds for decontamination and decommissioning constitutes a set of compounds that are not routinely encountered for most industrial solidification situations. Those commercial companies that have worked within the DOE structure maintain the proprietary knowledge to address this issue. A systematic survey of organic compounds and their effects upon Portland cement-based waste forms should be conducted. The resolution of the potential for biological degradation in realistic disposal scenarios should be conducted.

Non-Portland Cement. Only a few studies of non-OPC-based waste forms have been reported. Most of the studies involve high alumina and alkali-activated cements. Magnesium phosphate cements are reported with results being uncertain. Since these cements have not been as thoroughly explored as Portland cement, the possibilities of making significant breakthroughs are much higher than are the incremental contributions in the further study of the Portland system. A program to address the potential of alternative cementitious systems should be initiated. No studies involving non-OPC-based cements and organic compounds are known. This area offers immediate rewards.

\subsubsection{Encapsulation Waste Forms}

Limited R\&D studies have been completed, investigating the effectiveness of polymer encapsulation processes for specific types of waste and specific waste streams. Waste- and site-specific treatability studies to confirm process applicability for additional waste streams are required before implementing any emerging technology such as polymer encapsulation. Such studies investigate specific waste-binder compatibility, processing parameters (e.g., waste loadings), and key final waste form performance issues (e.g., leachability). For example, sulfur polymer encapsulation may be particularly well suited to specific problem wastes, (e.g., mercury) and waste-specific development work is needed to evaluate effectiveness. Since the U.S. Environmental Protection Agency is proposing much stricter release limits for toxic metals, additional work is recommended to evaluate the ability of polymer encapsulation to meet the new standards. In some cases, additional process modifications may be required. In some cases, additional testing to examine long-term durability under anticipated disposal conditions is needed. For example, current standard test methods for biodegradation testing (American Society for Testing and Materials [ASTM] G-21, G-22) were not designed for testing sulfur matrices. These tests should be appropriately modified to include sulfur attacking microbes and conducted to confirm product durability under disposal conditions. Optimization of full-scale processes and equipment is needed to "fine-tune" polymer encapsulation technologies. Especially critical is the development of systems that can expand the applicability of the technology by increasing tolerance to moisture and volatiles and broadening acceptable particle size range. Feasibility of encapsulating depleted uranium in polyethylene to use in shielding or ballast applications has been demonstrated. Additional work is needed to optimize this application and explore processing issues. 


\section{RECOMMENDED R\&D PROGRAM}

The preceding recommendations have been assembled into a proposed program plan, represented graphically in Figures 4 and 5. The objective of the program is to facilitate startup of a treatment process or processes that will prepare the bulk of the Department's MLLW inventory for disposal. Figure 4 is a logic diagram showing the relationships between activities and major milestones (decision points), and how data flows from one activity or decision point to other activities or decision points. Figure 5 is a Gantt chart illustrating relative scheduling data for the proposed activities and milestones. Work scope related to each of the top-level activities comprising the proposed program (and illustrated in Figures 4 and 5) is described below. The recommendations and technical deficiencies previously discussed can all be addressed by separate tasks organized under the activities described below. In some cases, the required tasks are already being funded under existing programs.

\section{Performance Evaluation}

Use performance evaluation and/or performance assessment methodologies to establish criteria for waste package performance that will ensure waste acceptance at virtually any realistic disposal facility. This activity primarily supports Decision Milestone 3, Waste Form Performance Criteria, but also provides valuable input to Decision Milestone 1, Waste Form Selection Criteria, Decision Milestone 5, Waste Form Improvement Objectives, and Decision Milestone 2, Data Needs.

\section{Systems Analysis}

Perform systems analysis studies to support strategic decisions regarding economic and schedule tradeoffs, and to help integrate political and stakeholder issues into total system optimization. This activity will help define the number, size, and location of treatment and disposal facilities, as well as the size and role of the transportation system. This activity should also serve as a feedback loop to integrate data from field testing into design of full-scale treatment and disposal systems.

\section{Waste Form Performance Sensitivity Analysis}

Evaluate waste form performance characteristics to identify those characteristics most critical for acceptable waste package and disposal facility performance. The analysis should include process parameters, and results should be sufficiently quantitative to provide major input to Decision Milestone 1, Waste Form Selection Criteria.

\section{Waste Inventory Characterization Data}

Gather detailed chemical and physical characterization data on the existing MLLW inventory to support evaluations of candidate waste forms and associated processes for compatibility. This activity primarily supports to Decision Milestone 1, Waste Form Selection Criteria, but will also provide useful input to Activity 2.

\section{Testing Methods Development}

Develop a set of testing methods that will allow direct comparison of waste form performance and provide a standardized data base for use in performance evaluations and waste form and process development. Decision Milestone 2, Data Needs, provides input to this activity, and the output is a set of test methods for standardization in Activity 6, Testing Methods. 


\section{Testing Methods}

Standardize the test methods developed in Activity 5, Testing Methods Development, through a recognized organization such as ANSI or ASTM. These standards will be used in Activity 8, Waste Form Optimization and Activity 10, Verify Waste Form Performance. Note that some standards have already been developed for glass and cement waste forms, but may require modification depending on the outcome of Activity 5, Testing Methods Development.

\section{Natural Analogue Studies}

Expand the study of natural analogues to improve confidence in long-term predictions of the behavior of all candidate waste forms. Some data pertinent to the behavior of glass and ceramic waste forms are already available. Efforts should concentrate on improving the data base for cement and metal waste forms, and initiating a search for natural analogues relevant to other candidate waste forms. This activity provides input to Decision Milestone 3, Waste Form Performance Criteria, and can also be very helpful obtaining stakeholder acceptance of proposed waste packages and disposal sites.

\section{Waste Form Optimization}

This activity focuses on waste forms and processes selected for implementation in Decision Milestone 4, Waste Form Down-Selection. Information from other appropriate activities is integrated and used to finalize waste form compositions and design field tests to evaluate the performance of selected processes and waste forms by treating actual waste. This activity provides a major input to Activity 9 , Field Testing.

\section{Field Testing}

Construct and operate field tests designed in Activity 8, Waste Form Optimization. This activity will provide a practical experience base for design, construction, and operation of full-scale treatment facilities, and provides major input to Activity 10, Verify Waste Form Performance.

\section{Verify Waste Form Performance}

Apply the standardized test methods established in Activity 6, Testing Methods, and information from Activity 1, Performance Evaluation, and other pertinent activities to evaluate the performance of waste forms produced in Activity 9, Field Testing. This activity provides verification of waste form acceptability before design, construction, and operation of a full-scale treatment facility(ies). 


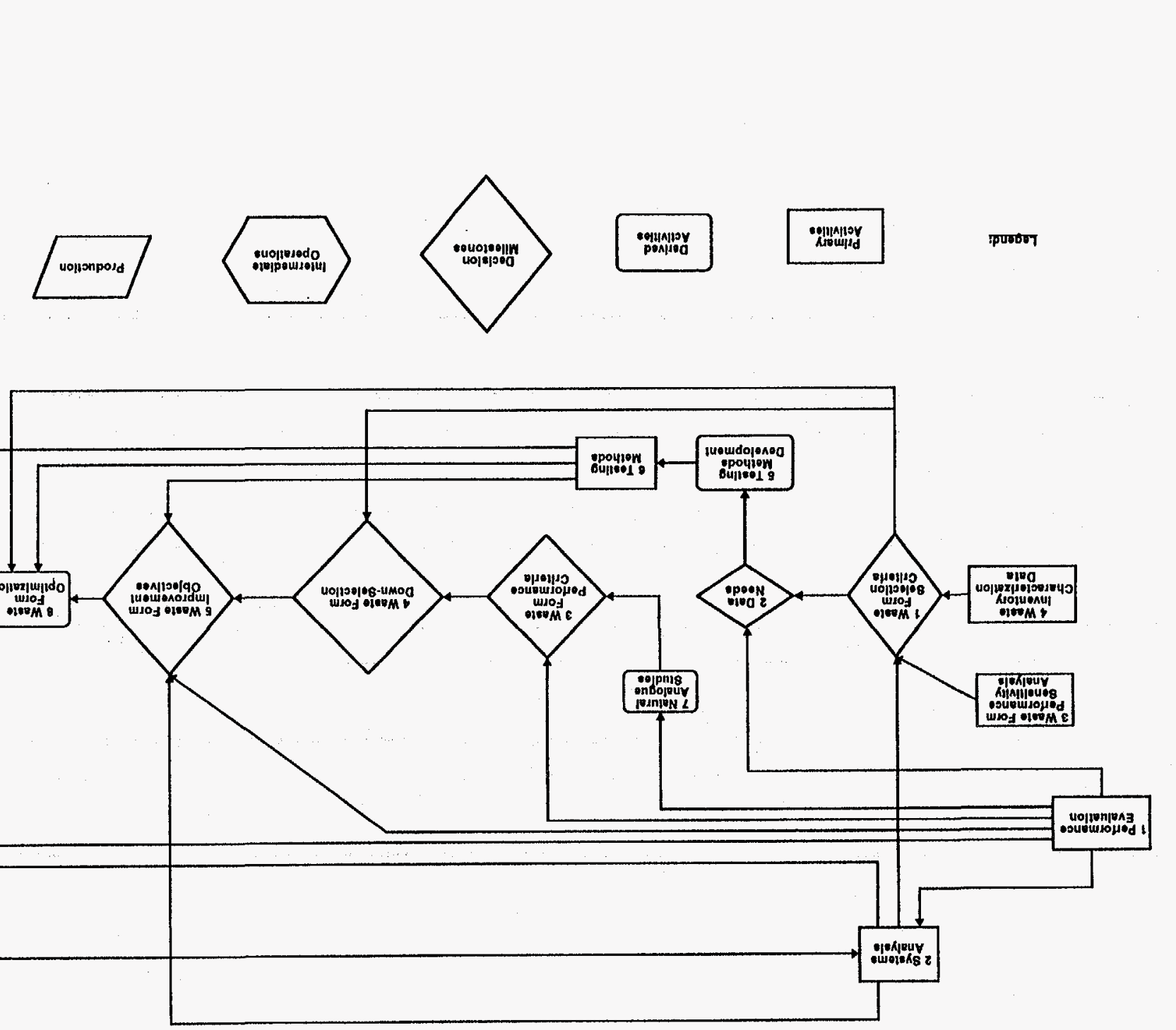

몽

娄

腾

政

ए

응

웡

.

年

은

苗望

क्ष

जै

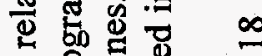

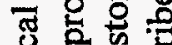

응

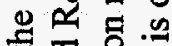

$5 \%$

월

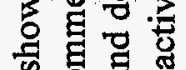

目

5.

敋

눈

要求

过

n

+

은

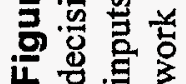


1 Performance

Evaluation

2 Systems

Analysis

3 Waste Form

Performance

Sensitivity

Analysis

4 Waste

Inventory

Characterization

Data

5 Testing

Methods

Development

6 Testing

Methods

7 Natural

Analogue

Studies

8 Waste

Form

Optimization

9 Field

Testing

10 Verify

Waste Form

Performance

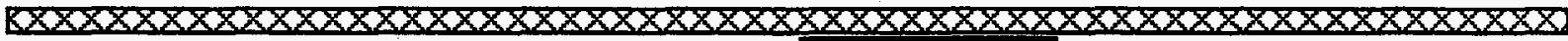

3 Waste Form

Performance

Criteria

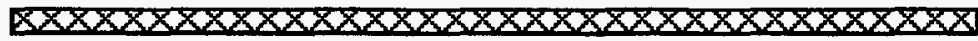

1 Waste Form

Selection

Criteria

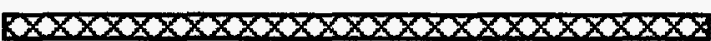

4 Waste Form

Down-

Selection

$\operatorname{sxx} \times x \times x \times x \times x \times$

2 Data

Needs $\times \times \times \times \times \times \times \times \times \times \times \times \times \times \times \times \times \times \times \times \times \times \times \times \times \times \times \times \times \times \times \times X$

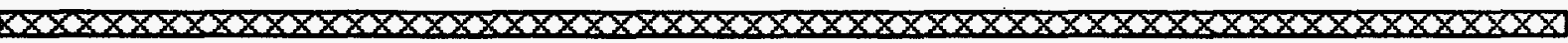

5 Waste Form

Improvement

Objectives $\times \times \times \times \times \times \times \times \times \times 8$

$\sin \times \sin \times \sin$

Figure 5. Gantt chart showing estimated schedule relationships between the activities and decision milestones shown in Figure 4. The time line on this chart nominally covers a period of five years, but can be altered by budget factors. The decision milestones from Figure 4 are shown in boxes on this chart. Full-Scale Operations appears in a round cornered box, and represents an end point for this R\&D program. R\&D activities supporting ongoing process improvement would normally continue during operations, but would then constitute a support function. 


\section{Appendix A}

Supporting Information for the Proposed Research and Development Plan for Mixed Low-Level Waste Forms 



\section{Appendix A}

\section{Supporting Information for the Proposed Research and Development Plan for Mixed Low-Level Waste Forms}

\section{A-1. INTRODUCTION}

\section{A-1.1 Objective}

The objective of the Department of Energy's (DOE's) Waste Form Task for FY 1996 is to recommend a waste form program plan that addresses waste form issues for mixed low-level waste (MLLW) from a systems perspective. The approach involves analyzing waste form issues and their interrelationships, comparing methods used to measure waste form performance with performance assessment/evaluation and regulatory needs, summarizing existing waste form information, identifying issues and requirements that are not being adequately addressed, and formulating a draft program plan to address the identified inadequacies. Diverse technical, legal, and political issues were incorporated into the analysis. Various waste form materials and geometries were considered, including potential hybrid waste forms (e.g., a vitrified waste form encapsulated in a salt-bearing polymer). The task integrated all related issues to address the fundamental question "How good is good enough?" for safe and costeffective disposal of mixed and low-level waste (see Figure A-1).

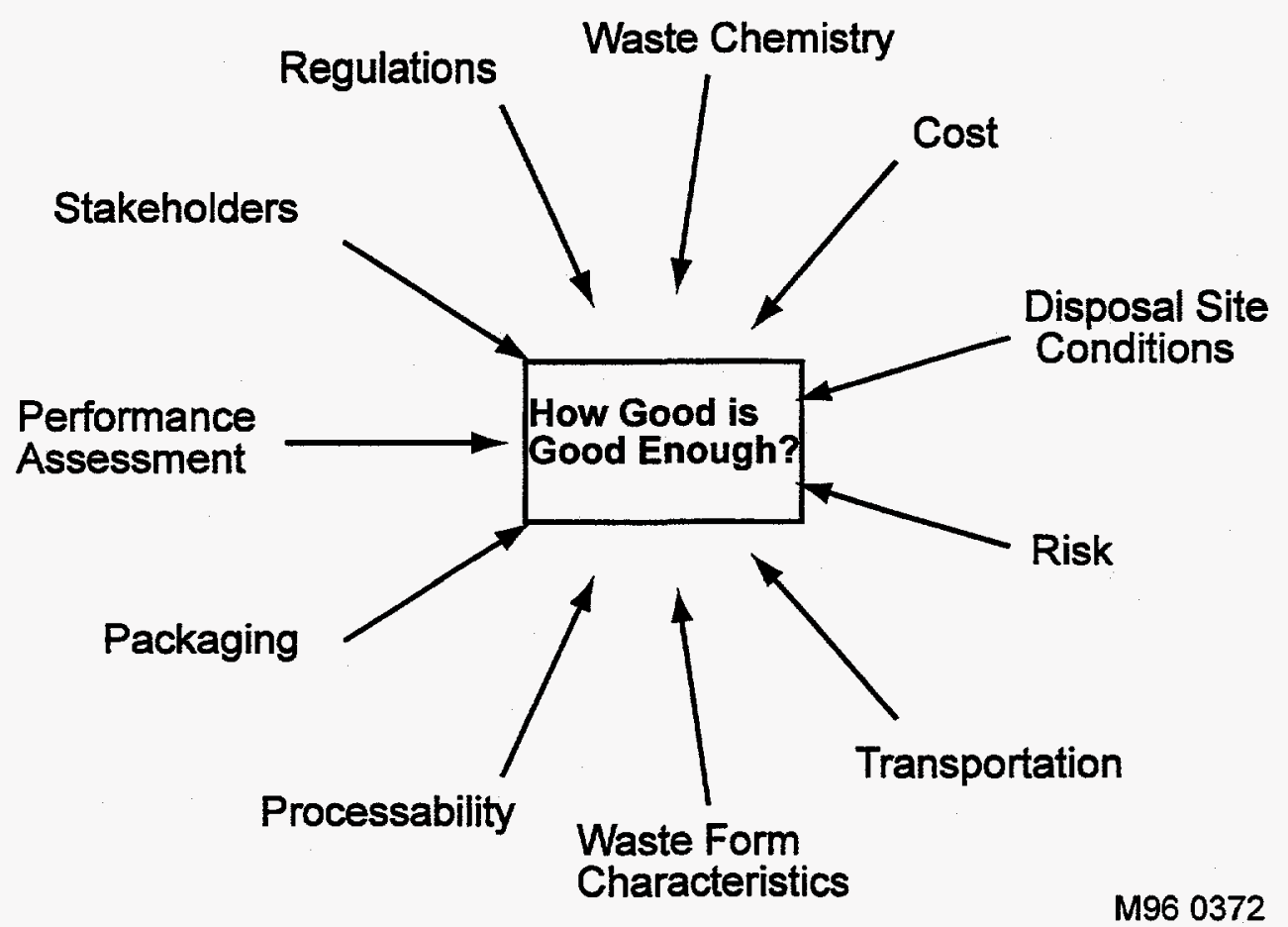

Figure A-1. Factors influencing appropriateness of waste form. 


\section{A-1.2 Technical Approach}

This report uses currently available information to compare the suitability of proposed waste forms for immobilizing existing waste types for permanent near-surface disposal. This analysis reveals deficiencies in the current "state of the art" from which programmatic research and development (R\&D) needs were derived, and identifies the bases for the proposed activities. Proposed R\&D activities were prioritized based on potential impact to DOE's mixed waste management mission. Input from recognized experts in waste form development has been used to perform this analysis.

A discussion of pertinent waste form properties and related issues precedes waste form analysis to put the analysis into perspective. Next, an overview is presented of waste forms currently under consideration for mixed and low-level waste disposal. To maintain a programmatic focus on the problem at hand, the array of waste forms currently under consideration are grouped into four categories based on common materials or processing characteristics:

1. High-temperature waste forms (e.g., glass, ceramic, glass-ceramic, iron enriched basalt)

2. Hydraulic cements (e.g., Portland-type cements, FUETAP cements, phosphate-bonded ceramics, gypsum-based cements)

3. Encapsulants (e.g., thermoplastics, thermosets)

4. Specialty waste forms (e.g., amalgams).

The waste form discussion identifies the materials and processing characteristics that are needed for assessing waste stream compatibility and the acceptability of the resulting waste forms for near-surface disposal. The waste form discussion also identifies the nature of any secondary waste streams, as well as the waste forms and processes applicable for immobilizing secondary waste streams.

The relative merits and disadvantages of waste forms typifying each of the four waste form groups for immobilizing large-volume DOE waste streams have been evaluated and compared to assess general suitability for treating DOE's MLLW inventory. This analysis takes into account the compatibility of the waste stream chemistry with the waste form fabrication process, the volume of stabilized waste requiring disposal (including processes and waste forms to stabilize secondary wastes), system costs, and risks. Criteria for evaluating the waste forms have been identified from the preceding issues analysis, process limitations, regulatory requirements, and input data needed for disposal site performance assessments.

Technical deficiencies have been redefined as programmatic $R \& D$ needs. Technical activities proposed to address these $R \& D$ needs are identified in the main body of the report. The proposed activities are prioritized based on potential pay-offs for the Department's mixed waste management mission. This analysis relies on expert judgement by recognized leaders in the waste form development field. 


\section{A-1.3 Issues}

\section{A-1.3.1 Stakeholders}

Stakeholders have a unique, often nontechnical, perspective on the waste form question. This is not really a single issue, but a combination of issues such as political factors, the "not in my back yard" problem, and effects on the local economy to name a few. Part of the difficulty dealing with these issues is that they can be as diversified as the stakeholders themselves. However, stakeholder buy-in is crucial for the success of any waste treatment and disposal system.

\section{A-1.3.2 Regulations}

The regulatory issue is particularly complicated for mixed waste, which, by definition, contains both hazardous and radioactive components. Therefore, it falls under the jurisdiction of both the U.S. Environmental Protection Agency (EPA) and the U.S. Nuclear Regulatory Commission (NRC). These two agencies have different approaches to dealing with the same waste. Proscriptive regulations can lead to waste form requirements with little technical value (e.g., TCLP data has little relevance to waste form performance).

\section{A-1.3.3 Waste Chemistry}

Mixed and low-level waste streams have a wide range of chemical and physical properties. Not all waste forms are compatible with all waste streams. The diversity of waste properties also presents processing challenges.

\section{A-1.3.4 Cost}

Cost is a complex issue because of the many factors contributing to system cost, and because the value of money changes with time. This complicates both the calculation of costs, and interpretation of the results.

\section{A-1.3.5 Disposal Site Conditions}

Disposal site conditions can have a decisive influence on waste form performance. Furthermore, disposal site performance is usually the specified variable for waste disposal. Waste form performance requirements are then derived from disposal site performance requirements.

\section{A-1.3.6 Risk}

Risk has several components, including health risks, environmental risks, and technical risks. Assessing risk is more difficult than assessing other issues because risk is quantified in terms of probabilities. 


\section{A-1.3.7 Transportation}

Transportation imposes unique requirements on waste forms that may be unrelated to waste form performance in a disposal facility. For example, drop test specifications may impose limits on the respirable dust generated in an impact event. Drop test specifications would therefore give rise to additional mechanical specifications for the waste form unrelated to disposal performance.

\section{A-1.3.8 Waste Form Characteristics}

Data on waste form characteristics is plentiful, but of limited utility in predicting waste form performance over long time intervals under field conditions. Much of the data was collected in laboratory tests designed more to measure waste form characteristics to support development work than to simulate waste form behavior in the environment. Also, test results from dissimilar waste forms (e.g., glass and grout) are not always directly comparable. Different corrosion mechanisms necessitate different testing methods to produce meaningful results. However, corrosion mechanisms are better understood for some waste forms than for others. The existing data needs to be integrated so that waste forms can be compared on a common basis. The data may require additional refinement to provide more accurate and realistic estimates of long-term performance.

\section{A-1.3.9 Processability}

Not all waste forms and their associated production processes are suitable for immobilizing all (or all components of) waste streams. Thus, a given site or waste stream may require more than one waste form for immobilization. Furthermore, some processes can tolerate greater variations in input characteristics than others while still producing a product that meets specifications. Processing issues should be addressed as early as possible during development because processes that are difficult to control will likely be difficult to implement.

\section{A-1.3.10 Packaging}

Packaging can interact with waste forms in a variety of ways. Packaging can influence the final waste volume going to disposal if, for example, the packages cannot be completely filled with the waste form. Packaging materials can influence waste form performance by delaying contact with water, or by corroding to products that retard (or promote) the release of radionuclides or toxic elements.

\section{A-1.3.11 Performance Assessment}

Performance assessment is a detailed methodology for estimating the long-term performance of the waste form/disposal site system. It draws upon data from the field and from the laboratory, combining the information with assumptions and using elaborate calculations to construct a dynamic model of the waste form/disposal site system. This approach is necessary because we lack a detailed understanding of long-term waste form performance in the field. As a consequence, performance assessment results are often as sensitive to the assumptions that must be made as they are to variability in the input data themselves. Attempts have been made to improve confidence in this approach by studying natural analogues of waste forms that have been exposed to field conditions for extended periods of time. However, unifying the results of natural analogue studies and laboratory tests has proven difficult. 


\section{A-2. PERTINENT WASTE FORM PROPERTIES}

The primary role of a waste form material is to provide a stable medium to contain the contaminants of concern. An ideal waste form material would be sufficiently resistant to degradation to prevent the release of such contaminants into the environment. More realistically, a practical waste form material will control the rate of release of such contaminants to acceptably low values over the range of conceivable environmental conditions to which the waste form will be exposed. The difficulties of developing such materials, and as importantly, in validating their ability to meet such requirements, are then immediately apparent and involve such controversial issues as "What is acceptably low?" and "What is the range of conceivable environmental conditions?" Resolution of these issues involves diverse areas of scientific expertise, legislation and regulation, and stakeholder interests. The challenge to the waste form developer therefore goes beyond the mere chemistry, physics, and material science of the problem since the "goal" is often not well- or even unambiguously specified. Despite these difficulties, various groups have reached and documented consensus opinions relating to characteristics of a "good" waste form and a logical approach to the difficult issue of predicting materials behavior (Pegg et al.,1990; ASTM 1991).

In some instances, standardized test methods have been developed to assess the pertinent characteristics of a waste form and, particularly in the regulatory arena, specific limits have been promulgated for these characteristics. Thus, while there still exists considerable debate on the specific test methods and limits, defining such targets provides a valuable guide in the waste form development and selection process. In the following sections, the status of test methods and standards that have been used to assess pertinent waste form properties is briefly reviewed. These methods are grouped here into "regulatory tests," which typically include pass/fail limits on the property measured, and "laboratory tests," which have typically been developed to understand and compare the release characteristics of waste forms undergoing aqueous corrosion.

\section{A-2.1 Regulatory Tests}

Regulatory tests are waste form tests prescribed by regulatory agencies. These tests generate data that are compared to criteria established by the regulating agencies to determine regulatory acceptability of the waste form. All waste forms are subject to these tests.

Regulatory tests for MLLW are specified by the EPA and the NRC. The EPA tests are used to measure the hazardous characteristics of ignitability, corrosivity, reactivity, and toxicity as defined in the Resource Conservation and Recovery Act (RCRA) at 40 CFR 261. The tests used to measure these characteristics are listed in Table A-1. These tests provide pass/fail criteria for the four hazardous characteristics. A waste or waste form that fails any of these tests is "hazardous" from a legal perspective. Thus, one objective of waste treatment is to convert the waste to a form (the waste form) that passes these tests and is therefore no longer hazardous. However, "listed" RCRA waste remain listed RCRA waste after treatment, even if the waste form passes these tests. The treated waste may, however, be suitable for land disposal once the hazardous characteristic is removed. 
Table A-1. Tests to determine RCRA hazardous characteristics.

\begin{tabular}{lll}
\hline Characteristic & \multicolumn{1}{c}{ Standard Test } & \multicolumn{1}{c}{ Comments } \\
\hline Ignitability & $\begin{array}{l}\text { ASTM D-93-79, D-93-80, } \\
\text { or D-3278-78 }\end{array}$ & $\begin{array}{l}\text { Standard tests are specified for liquids, additional } \\
\text { (non-standardized) ignitability tests are described } \\
\text { at 40 CFR 261.21 and by reference at } \\
49 \text { CFR } 173 .\end{array}$ \\
Corrosivity & Not specified & $\begin{array}{l}\text { pH }<2 \text { or }>12.5 \text { as determined by pH meter using } \\
\text { methods described in EPA Publication SW-846. }\end{array}$ \\
& Not specified & Criteria are described at 40 CFR 261.23. \\
Reactivity & TCLP & The TCLP test is described in EPA Publication \\
Toxicity & & $\begin{array}{l}\text { SW-846. Substances of concern and regulatory } \\
\text { limits are listed in Table 1 of 40 CFR 261.24 (b). }\end{array}$ \\
\end{tabular}

In a Technical Position Paper (NRC 1991), the NRC recommended a set of tests and associated limits that LLW and waste forms should meet to be acceptable for shallow land disposal. The recommended standard tests along with the characteristic they measure are listed in Table A-2.

Note that every test listed in Table A-2 except the free liquids test and the leach resistance test is followed by another compressive strength test. Furthermore, it is recommended that the leach resistance test be used as the immersion test. That is, a compressive strength test performed on the sample used in the leach resistance test can provide the data for the immersion test. The suite of tests recommended by the NRC can be summarized as follows:

- A leach resistance test

- A free-liquids test

- A compressive strength test on a virgin sample

- Compressive strength tests performed on samples exposed to various stresses.

Leach test results are, of course, of interest for predicting radionuclide release from the waste form, a parameter particularly important to performance assessment. However, radionuclide release also depends on water flow through the disposal unit. The interest in compressive strength arises from the view that subsidence of the disposal facility must be controlled since it has the undesirable effect of increasing water flow through the facility, and thereby leads to increased radionuclide release rates. Therefore, the NRC tests examine the impact of potential degradation mechanisms (freeze-thaw cycling, radiation, biological activity, and immersion) on the compressive strength of the material. This test suite does not, however, address the impact of potential degradation mechanisms on the intrinsic leach resistance of the material (except accidently through any unlikely correlations between leach resistance 
and compressive strength), which will also affect radionuclide release rates. All tests listed in Table A-2 are NRC recommendations, except for the TCLP leach resistance test, which is an EPA-specified test.

Table A-2. Tests for various waste form characteristics.

\begin{tabular}{lll}
\hline Characteristio- & \multicolumn{1}{c}{ Standard Test } & \multicolumn{1}{c}{ Comments } \\
\hline Compressive & ASTM-C-39, ASTM-D-1074 & ASTM-C-39 is intended for cement waste \\
strength & forms, and ASTM-D-1074 is intended for \\
& bitumen waste forms. Compressive strengths \\
& $>0.41 \mathrm{MPa}$ are recommended, $>3.45 \mathrm{MPa}$ for \\
& cement-bonded waste forms.
\end{tabular}

$\begin{array}{lll}\begin{array}{l}\text { Thermal cycle } \\ \text { (freeze-thaw) } \\ \text { resistance }\end{array} & \text { ASTM-B-553 } & \begin{array}{l}\text { Must pass compressive strength test after } \\ 30 \text { cycles between }-40^{\circ} \mathrm{C} \text { and } 60^{\circ} \mathrm{C} .\end{array} \\ \begin{array}{l}\text { Radiation } \\ \text { stability }\end{array} & \text { N.A. } & \begin{array}{l}\text { Must pass compressive strength test after } \\ 10^{8} \text { rads gamma exposure. Addresses } \\ \text { long-term cumulative dose effects on } \\ \text { mechanical strength. Potential dose rate } \\ \text { effects not addressed. }\end{array}\end{array}$

\begin{tabular}{lll}
$\begin{array}{l}\text { Biological } \\
\text { stability }\end{array}$ & ASTM-G-21, ASTM-G-22 & Followed by compressive strength test. \\
Immersion & See comments & $\begin{array}{l}\text { Must pass compressive strength test after } \\
90 \text { day immersion. Recommend using same } \\
\text { sample used for leach resistance test. }\end{array}$ \\
Free liquids & ANSI/ANS 55.1 Appendix 2 & $\begin{array}{l}<0.5 \text { volume \% free liquid, } 4 \leq \mathrm{pH} \leq 11(\mathrm{pH} z \\
9 \text { for cement-solidified aqueous streams) }\end{array}$ \\
$\begin{array}{l}\text { Leach } \\
\text { resistance }\end{array}$ & ANSI/ANS 16.1, TCLP & $\begin{array}{l}\text { Leachability Index }>6.0 \text { for each radionuclide } \\
\text { of concern. Mathematically treats release as } \\
\text { diffusion through the surface of the waste } \\
\text { form into solution; not appropriate for many } \\
\text { waste forms.Element-specific TCLP limits } \\
\text { (RCRA) }\end{array}$ \\
\hline
\end{tabular}

Regulatory tests provide a well-defined minimal set of characteristics that waste forms must meet and therefore have the distinct benefit of providing clear minimal design objectives for waste form development or selection. However, it is important to note that it is not necessarily sufficient that a waste form meet these criteria; in particular, performance assessments that take into account the specific disposal scenario, local site environment, and waste inventory may lead to tighter constraints on the leach resistance of the waste form. 


\section{A-2.2 Laboratory Tests}

Test methods that are not specifically required by regulatory agencies are referred to here as laboratory tests. These tests are usually performed to provide additional cilariaterization data on wisie forms, to allow quantitative cenparisons between waste forms, to provide feeöruok to minet n development and selection activities, and to investigate waste form alteration mechanisms. These data provide critical input to the source term model used in performance assessments that attempt to quantitatively predict the long-term behavior of a disposal site. Given the central role of the leach resistance of the waste form in controlling release from the disposal site, it is not surprising that a great many test methods have been developed to address waste form leach resistance. Unfortunately, unlike objective properties such as density or compressive strength, "leach resistance" is considerably more subjective.

Leach resistance depends on a large number of experimental variables, most of which may be important in an actual disposal scenario and which cannot, therefore, be neglected. Test methods for leach resistance typically involve the specification and standardization of a set of values for these experimental variables and the definition of a measurable response variable to represent the property called "leach resistance." As an example, the test method might specify the temperature, surface area of the waste form sample, volume of the leachant, composition of the leachant, test duration, and test vessel material, and further specify that the concentration of a particular element in solution relative to its concentration in the waste form be used as a measure of leach resistance. However, tests methods for leach resistance also differ with respect to numerous other factors, such as the method of preparation of the waste form sample (e.g., powders or monoliths), ambient atmosphere (e.g., oxidizing vs. reducing, availability of carbon dioxide which affects leachate $\mathrm{pH}$ ), leachant flow rate, sampling and analysis methods, and specific test configuration.

Unfortunately therefore, the number of potential "standard" test methods for this property is essentially limitless. The utility of such standard test methods is in providing the ability to compare waste forms on a common basis, but it is important to recognize that none of these methods, so far as is presently known, provides an "absolute" measure of the desired property called "leach resistance." Essentially, each method sets up a reaction (usually chemical but conceivably purely physical) between the waste form and the leachant under controlled conditions and determines by measurement of some response variable (such as weight loss, solution concentration, reacted layer thickness) an indication of the extent of reaction. the leachant is typically an aqueous solution, or pure water in either the liquid or vapor form. Several conclusions are then immediately apparent:

1. The test results will depend on the values of all of the experimental variables that define the test conditions and will therefore differ from test to test.

2. The dependence of the test results on the test variables need not be linear, so that even the ranking of waste forms obtained on one test (i.e., the conclusion that waste form $A$ is "better than" waste form B) may not agree with the ranking obtained on a different test.

3. Any attempts to relate the results obtained on one test method to those obtained on another test method implicitly assumes a knowledge of how the response variable depends on each of the experimental variables for which the two tests differ. For example, if two otherwise 
identical tests are conducted at different leachant $\mathrm{pH}$ values, any meaningful comparison of the results requires a knowledge of how the reaction rate depends on $\mathrm{pH}$.

In summary, therefore, each of the multitude of test methods for leach resistance probes the extent of the overall reaction process when the experimental variables are set at particular values (the test conditions) and, in that respect, provides only a particular "snapshot" of a complex process that is both evolving in time and dependent on a large number of variables. Attempts to develop a mechanistic understanding of the reaction process often involve the systematic variation of one of the experimental parameters at a time, sometimes using a standard test method as the basis. Ultimately, a complete and quantitative mechanistic understanding of the reaction process is sought since this would both integrate the experimental data relating to diverse test conditions and provide a logical basis for predicting the long-term behavior of the waste form under the anticipated disposal conditions. While more progress has been made in this direction for some waste forms than for others, the general complexity of this problem places this "ultimate model" solution many years in the future. Pragmatically, therefore, waste form disposal, and certainly waste form development and production, has had to rely on a less complete understanding of the long-term behavior of waste form materials in potential disposal scenarios.

In particular, a considerable amount of data on the leach behavior of glass waste forms has been accumulated from HLW vitrification programs around the world. Many of the testing procedures developed specifically for glass waste forms have been standardized and most differ significantly from the ANSI/ANS-16.1 test specified by the NRC for LLW forms and from the TCLP test specified by the EPA. Laboratory tests that are commonly applied to assess the leach resistance of glass waste forms are listed in Table A-3.

Most of the basic test methods listed above have spawned a number of variants that individual researchers have found useful for specific investigations. As discussed above, the test conditions imposed by each test method will determine the "stage" in the overall reaction process that the test method probes. Thus, some test methods tend to measure the initial stages of reaction, others intermediate stages, while still others emphasize the later stages. In the sense used here, the distinction between "late" and "early" relates to the reaction progress.

What is at issue from a practical perspective, however, is how to relate this to the behavior in real time since that is the variable of concern in performance assessments. The magnitudes of the times of interest are obviously beyond what is reasonably accessible experimentally. For this reason, "accelerated" tests seek to increase the rate of reaction to achieve a greater extent of reaction in an experimentally accessible period of time. The ability to accelerate the reaction and, what is more important and much more difficult, the ability to relate the data to a corresponding point in time under non-accelerated conditions, again rests on a mechanistic understanding of the corrosion process. The most commonly used accelerating factors are the temperature and the ratio of the glass surface area to the volume of leachant ( $\mathrm{S} / \mathrm{V}$ ratio), although chemical acceleration (e.g., leaching under artificially high pH conditions, if that is believed to accelerate the reaction under consideration) has also been used.

The Soxhlet test (ISO, DOE 1981) has been used extensively in the HLW vitrification development programs in Europe and Japan and was used early in the U.S. program. This test method typically employs a monolithic sample, a still, and a refluxing assembly. Water is boiled in the still, condensed in 
a reflux condenser, and then allowed to flow back over the waste form sample. Leaching therefore takes place at close to $100^{\circ} \mathrm{C}$ when the test is performed under atmospheric pressure.

Table A-3. Laboratory tests commonly used to measure leach behavior of glass waste forms.

\begin{tabular}{|c|c|c|c|c|}
\hline Test & Sample & Leachate & Temperature & Duration \\
\hline $\begin{array}{l}\text { Soxhlet (also } \\
\text { MCC-5) }\end{array}$ & Monolithic & $\begin{array}{l}\text { Deionized water; flow } \\
\text { (reflux) }\end{array}$ & $100^{\circ} \mathrm{C}$ & $\begin{array}{l}1 \text { to } 7 \text { days nominal; } \\
90 \text { days common }\end{array}$ \\
\hline $\begin{array}{l}\text { MCC-1 (Materials } \\
\text { Characterization } \\
\text { Center) }\end{array}$ & Monolithic & $\begin{array}{l}\text { Deionized water, } \\
\text { ground water; static }\end{array}$ & $40,70,90^{\circ} \mathrm{C}$ & 14,28 days \\
\hline MCC-3 & Powder & $\begin{array}{l}\text { Deionized water, } \\
\text { ground water; static }\end{array}$ & $\begin{array}{l}40,90,110 \\
150,190^{\circ} \mathrm{C}\end{array}$ & 7 days \\
\hline $\begin{array}{l}\text { PCT-A (Product } \\
\text { Consistency Test) }\end{array}$ & Powder & Deionized water; static & $90^{\circ} \mathrm{C}$ & 7 days \\
\hline PCT-B & Powder & $\begin{array}{l}\text { Deionized water, } \\
\text { other; static or with } \\
\text { replacement }\end{array}$ & Any & $\begin{array}{l}\text { Any (up to } 8 \text { years } \\
\text { ongoing) }\end{array}$ \\
\hline Pulsed-Flow & $\begin{array}{l}\text { Crushed or } \\
\text { monolithic }\end{array}$ & $\begin{array}{l}\text { Deionized water, } \\
\text { ground water, other; } \\
\text { flow (partial } \\
\text { replacement) }\end{array}$ & $\begin{array}{l}\text { Any but } \\
\text { typically } 20 \text { to } \\
90^{\circ} \mathrm{C}\end{array}$ & $\begin{array}{l}1 \text { day to } 15 \text { years } \\
\text { (ongoing) }\end{array}$ \\
\hline IAEA & Monolithic & $\begin{array}{l}\text { Deionized water; } \\
\text { periodic total } \\
\text { replacement }\end{array}$ & $\begin{array}{l}25^{\circ} \mathrm{C} \text { nominal, } \\
\text { others typical }\end{array}$ & $\begin{array}{l}1 \text { day to } 18 \text { years } \\
\text { (ongoing) }\end{array}$ \\
\hline Vapor Hydration & Monolithic & Water vapor; static & 75 to $260^{\circ} \mathrm{C}$ & 7 to 100 days \\
\hline Drip & Monolithic & $\begin{array}{l}\text { Deionized water or } \\
\text { solutions, dynamic }\end{array}$ & $90^{\circ} \mathrm{C}$ & several to $>100$ days \\
\hline Initial Rate & Crushed & $\begin{array}{l}\text { Buffer, deionized } \\
\text { water; flow }\end{array}$ & $\begin{array}{l}\text { Typically } 20 \text { to } \\
90^{\circ} \mathrm{C}\end{array}$ & $>7$ days, typically \\
\hline TCLP $^{\mathrm{a}}$ & Crushed & Buffer ( $\mathrm{pH} 5)$ & $22^{\circ} \mathrm{C}$ & $18 \mathrm{hrs}$ \\
\hline ANSI/ANS $16.1^{\mathrm{a}}$ & Monolithic & Deionized water & 17.5 to $27.5^{\circ} \mathrm{C}$ & 90 days \\
\hline
\end{tabular}

In this test, the leachant contacting the sample is constantly replaced with freshly distilled water while the material that is leached from the ample is concentrated in the still below. Solution samples are removed from the still periodically and the leach rate is determined from the analyzed solution 
concentrations; the mass loss of the sample can also be used to determine the leach rate. Typical S/V values are around $10 \mathrm{~m}^{-1}$ and flow rates are around $1 \mathrm{~cm}^{3} / \mathrm{min}$. (with a hold-up volume of about $50 \mathrm{~cm}^{3}$ ). This test therefore probes the initial rate of reaction under high-dilution conditions.

The MCC-1 test (DOE 1981) uses a monolithic sample that is suspended within the leach vessel and completely immersed in the leachant. The assembly is held at a constant temperature for the duration of the test after which time the leachate is sampled and analyzed. Typical $\mathrm{S} / \mathrm{V}$ ratios are close to $10 \mathrm{~m}^{-1}$ and the flow rate is zero (static) for this test. While this test method still probes the early stages of reaction, it extends beyond tests such as the Initial Rate, Soxhlet, and IAEA tests.

The MCC-3 test (DOE 1981) uses a crushed and sieved sample with a nominal particle size between 149 and $175 \mu \mathrm{m}$. The sample is completely immersed in the leachant and the vessel is constantly agitated while being held at a constant temperature for the duration of the test; the leachate is then sampled an analyzed. Typical $\mathrm{S} / \mathrm{V}$ ratios are around $2000 \mathrm{~m}^{-1}$ and the flow rate is zero for this test. The difficulties (and relevance) of the constant agitation requirement have lead to extensive use of a modified procedure that omits the agitation (e.g., Feng 1988). This test probes intermediate to late stages (depending on the duration) of the reaction progress during which dissolved material has significantly modified the leachant (particularly with respect to $\mathrm{pH}$ ) and the solution concentrations can be sufficiently high to probe effects due to the precipitation of secondary phases. Reaction rates typically decline as the solution becomes more concentrated in the reaction products, but can increase again as the precipitation of secondary phases depletes the solution of some constituents; this effect is not usually evident in high-dilution tests.

The PCT test (ASTM 1994) is very similar to the modified MCC-3 procedure (without agitation), discussed above, and was developed as a direct result of the extensive use of the modified MCC-3 test method in the development of glass waste forms for the vitrification of high-level nuclear wastes at West Valley. In addition, a procedure such as the modified MCC-3 method was judged to be better suited to hot-cell operation that was the MCC-1 procedure (the basis for the original vitrified HLW acceptance specifications), since the latter required cutting a monolithic sample of well-defined surface area. The PCT-A procedure specifies deionized water as the leachant, a test temperature of $90^{\circ} \mathrm{C}$, a test duration of 7 days, and the use of 304L stainless steel vessels; it is presently the required acceptance test for vitrified HLW in the U.S. The PCT-B is a derivative of PCT-A that permits the use of other leachants, temperatures, times, $\mathrm{S} / \mathrm{V}$ ratios, and test vessels. PCT test on waste glasses with durations of over 8 years are still ongoing (VSL 1996).

The pulsed-flow test method (Barkatt et al. 1981) simulates the effects of leachant flow by the periodic replacement of some or all of the leachate by fresh leachant. By selecting the fraction to be replaced and the time between replacements, a very wide range of flow rates can be accessed. In particular, the very low flow rates that are expected in some disposal scenarios, which are difficult to achieve in a continuous-flow test, can be simulated with this procedure. The method typically uses a crushed and sieved sample but monoliths have also been used. A sample of the leachate that is removed at each replacement interval is analyzed to determine the concentrations of leached species. $\mathrm{S} / \mathrm{V}$ ratios are typically in the range of $10-2000 \mathrm{~m}^{-1}$ and average leachant flow rates range from about $1 \mathrm{~cm}^{3} /$ hour to $25 \mathrm{~cm}^{3} /$ year (typically $25 \%$ /hour to $25 \%$ /year of the leachant volume). The pulsed-flow method can probe the early stages of reaction at high flow rates and low $\mathrm{S} / \mathrm{V}$ values as well as the intermediate to late 
stages at lower flow rates and higher $\mathrm{S} / \mathrm{V}$ values. Tests of this type on waste glasses have been running continuously for over 15 years and are ongoing (VSL 1996).

The IAEA (IAEA 1979) and the ANSI/ANS 16.1 (ANSI/ANS 1986) procedures have much in common in that both use monolithic samples and a periodic total replacement of the leachate by fresh leachant; the replacement interval is initially short (a few hours), but is increased progressively over the duration of the test. Both procedures are nominally run at close to room temperature. A sample of the leachate obtained at each exchange is analyzed to determine the concentrations of leached species. The ANSI/ANS 16.1 procedure also includes data analysis in terms of a diffusional release model intended for cementitious waste forms. The ANSI/ANS 16.1 test has a total duration of 90 days with 10 samplings. IAEA tests have been run over a wide range of test durations and some tests have been running continuously for over 18 years and are ongoing (VSL 1996). The S/V ratios are typically around $10 \mathrm{~m}^{-1}$ for these tests and the flow rates decrease with time from maximum values of about $100 \mathrm{~cm}^{3} /$ day and $1,200 \mathrm{~cm}^{3} / \mathrm{day}$, for the IAEA and the ANSI/ANS 16.1 tests, respectively, when a leachant volume of $100 \mathrm{~cm}^{3}$ is used.

The TCLP procedure (U.S. EPA) uses $100 \mathrm{~g}$ of a sample that is size-reduced to pass a $3 / 8$-in. sieve, but with otherwise unspecified surface area; the volume of leachant is specified as 2 liters. The leachant is a sodium acetate buffer solution at close to $\mathrm{pH} 5$ and the test vessel is constantly agitated by end-over-end rotation at $30 \mathrm{rpm}$. The test temperature is $22^{\circ} \mathrm{C}$ and the duration is 18 hours. The leachate is analyzed for the RCRA elements and, if necessary, for hazardous organics (in which case a special "zero head space" extractor must be used). The $\mathrm{S} / \mathrm{V}$ ratio is not specified and can be highly variable; it is typically greater than about $20 \mathrm{~m}^{-1}$, depending on the sample particle size. (Modifications of this procedure for waste form development purposes have employed both upper and lower bounds on the particle size to improve the reproducibility.) Unless buffers are used, as in the TCLP test, leachates from glass waste forms tend to be quite alkaline as a result of the relatively rapid diffusional release of alkali elements. The TCLP test is therefore somewhat unusual in that it probes the leach resistance under acidic conditions, which greatly enhances the solubility of many constituents, notably the heavy metals. For this reason, although this test method appears to be relatively benign in terms of its lower temperature, shorter duration, and lower $\mathrm{S} / \mathrm{V}$ ratio than, for example, the PCT test, leachate concentrations of RCRA metals in the TCLP test are often found to be much higher than in ostensibly "more aggressive" tests because of their generally very low solubilities at high $\mathrm{pH}$.

Vapor hydration tests (Ebert, Bates, and Bourcier 1991) have been used to explore the later stages of glass corrosion that are dominated by secondary phase formation. These tests use a monolithic sample that is exposed to water vapor typically at temperature between 75 and $260^{\circ} \mathrm{C}$. The effective $\mathrm{S} / \mathrm{V}$ ratio is very high since the reaction occurs between a thin film of water, only a few monolayers thick, that is adsorbed on the surface of the sample. Since there is no significant amount of leachate for analysis, the primary data from these tests are obtained from analysis of the solid alteration products on the reacted sample, which typically involves electron microscopy and various spectroscopic techniques. Such tests provide a method of accessing the late stages of the corrosion process in a relatively short time, and can provide detailed information on the types and relative amounts of the secondary phases that form. Sample weight change and reacted layer thicknesses can also be determined.

So-called "drip" tests (Bates and Gerding 1985) have also been used to assess the leach resistance of glass waste forms. The tests use a monolithic sample in a sealed vessel that has the capacity for the 
periodic introduction of a small amount of leachant that is dripped over the sample. In this way, the sample is alternately exposed to humid conditions followed by contact with liquid water. The leachate is sampled and analyzed periodically to determine the release as a function of time. The motivation for such a test methodology is, firstly, that this is a realistic HLW repository scenario; and secondly, that the combination of relatively rapid reaction and surface alteration (but without transport) that occurs under humid conditions, coupled with contact with liquid water (to provide a transport mechanism), could potentially be an important mechanism in determining the overall release. Tests of this type have been conducted for durations of over 5 years.

The initial rate of reaction is a parameter of interest in the mechanistic interpretation of glass leaching processes and, consequently, several measurement methods have been developed. The objective is to determine the natural rate of reaction into an infinitely dilute (at least in reaction products) solution. It is generally of interest to determine this parameter as a function of both temperature and solution $\mathrm{pH}$. A typical practical arrangement consists of a crushed, sieved glass sample contained between screens in a flow-through cell (Knauss 1990). Leachant (typically a buffer solution) is pumped through the cell at a constant rate and samples are collected periodically for analysis. The leach rate is then calculated, the flow rate is increased, and the process is repeated. The initial rate is taken to be the leach rate obtained in the limit of high flow rate. Several of the other test methods can approach similar limiting conditions, notably the Soxhlet, IAEA, and ANSI/ANS 16.1 tests, and can therefore provide approximations to the initial rate.

The variety of tests methods that have been developed for determining what is ostensibly the same property-leach resistance-reflects the difficulties involved in determining such a complex and multi-faceted property. The ability to quantitatively interrelate the results from these tests still represents a formidable challenge, even for a single waste form-glass, which is perhaps one of the most studied waste forms with respect to this property. These considerations complicate comparison between waste forms since different test methods may be appropriate for different waste forms on the basis of a knowledge of how each particular waste form does or does not degrade. Such comparisons between waste forms is discussed in Section 4. 


\section{A-3. TREATMENT TECHNOLOGIES AND WASTE FORMS}

\section{A-3.1 General Considerations}

Waste treatment and disposal are interrelated processes. From a systems engineering perspective, the treatment and disposal system is composed of two subsystems: the waste treatment subsystem, and the waste disposal subsystem. Three primary segments define each subsystem, as illustrated by the triangles in Figure A-2. The three segments forming a subsystem triangle are also interrelated, and cannot be defined independently.

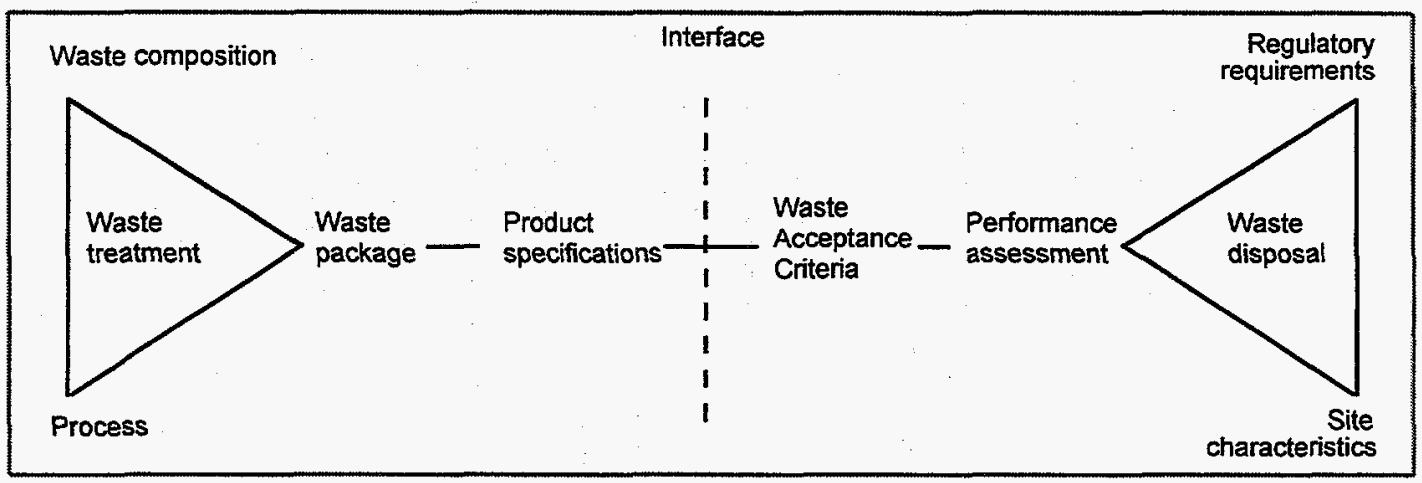

Figure A-2. Schematic diagram representing the primary segments of a waste treatment and disposal system. The treatment and disposal subsystems are defined by three interdependent descriptive segments. The two subsystems interact through the interface formed by two complimentary documents: the Product specifications generated by the waste treatment subsystem, and the Waste Acceptance Criteria generated by the waste disposal subsystem.

This study focuses on the waste package segment of the treatment and disposal system. Therefore, the following discussion deals primarily with the waste package, and describes other aspects of the system from the perspective of the waste package. The system segments of most immediate relevance to the waste package are the other two waste treatment segments, Waste composition and Process (see Figure A-2). These are discussed in more detail than the other segments. Since Product Specifications are generally unavailable, and Waste Acceptance Criteria exist only for a few specific sites, the interface between the two subsystems is not specifically addressed. Instead, aspects of the waste disposal segments that would influence the interface by defining performance characteristics are discussed in relation to waste form development and selection of waste forms/processes for treating waste streams.

\section{A-3.2 Waste Streams}

The current inventory of MLLW encompasses a wide variety of physical and chemical characteristics. Furthermore, the waste is not uniformly distributed across the complex. Some subcategories of waste are fairly homogeneous, whereas other subcategories are quite nonhomogeneous. In many cases, detailed characterization data are unavailable. However, a gross sense of the varied chemical and physical make-up of the Department's MLLW can be obtained by breaking the inventory down into what are referred to as "Matrix Parameter Categories" (MPCs) as defined in the DOE Waste Treatability Group Guidance (Kirkpatrick 1995), and shown in Figure A-3. 


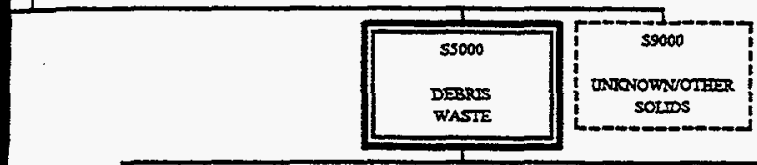

$\mathrm{X}$

SPECIFIC

WASTE

FORMS

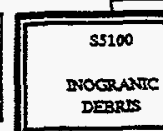

DERRES

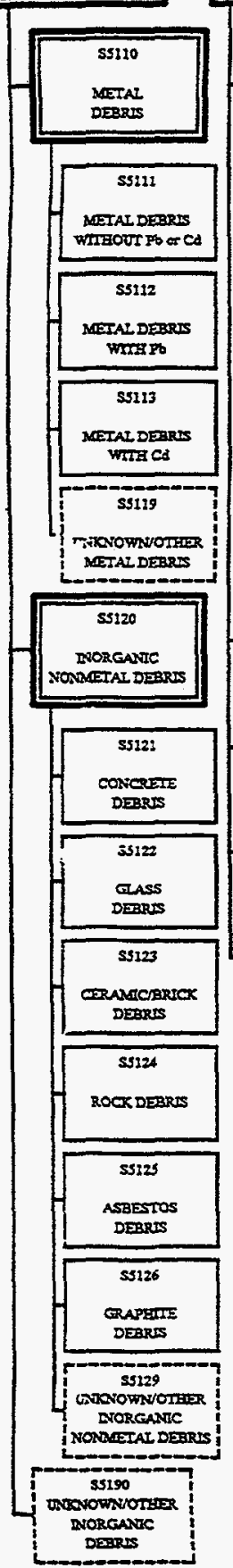

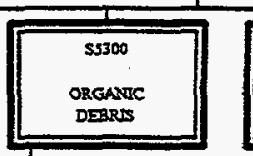

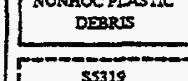

4 5s319

PLASTIC

ROBBITR DESRRS

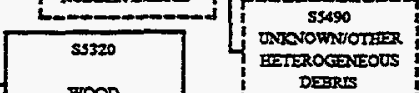

mOOD

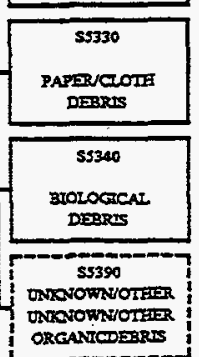

ORGANTCDEBRTS

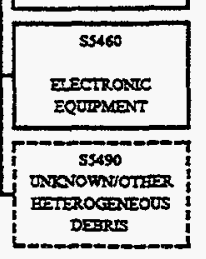

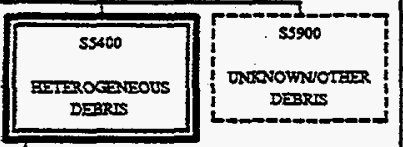

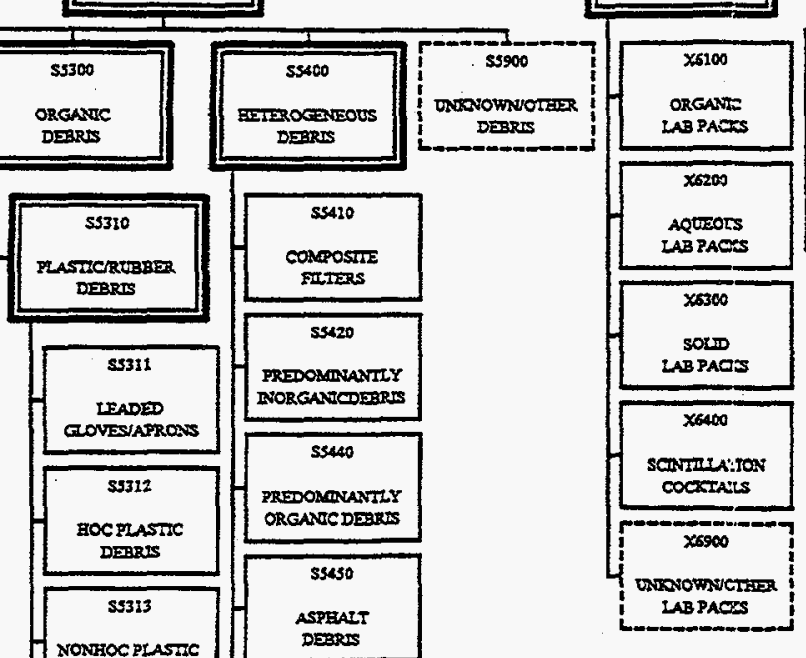

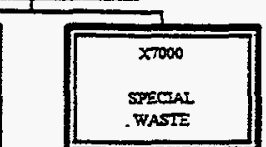
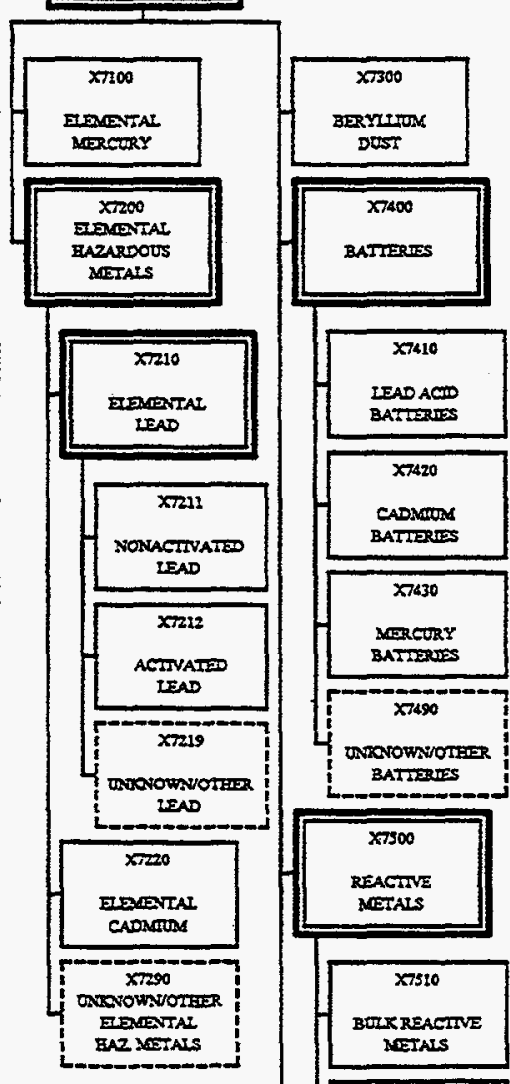

INAL WASTE

FORMS

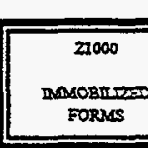

21

2100
$\operatorname{Mach} 0$

ENcapstLatzo

FORMS
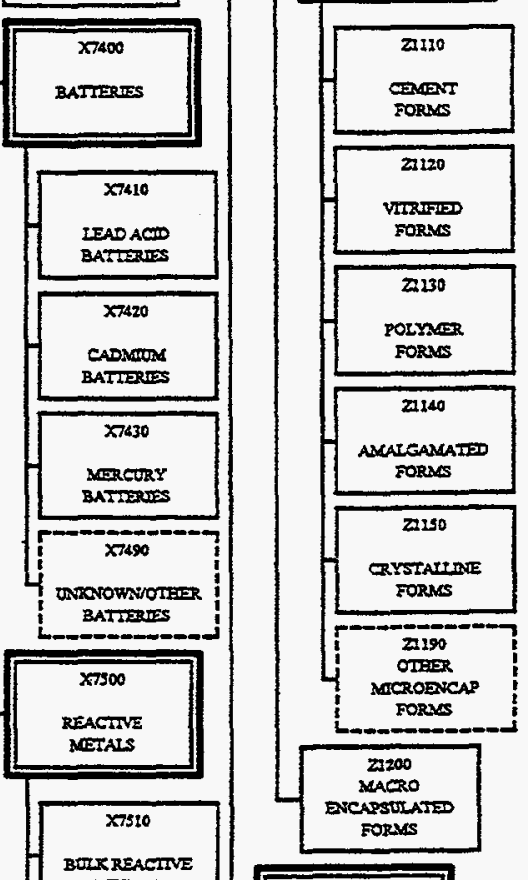
Forays

22150

GRYSTAUTDEE FORMS
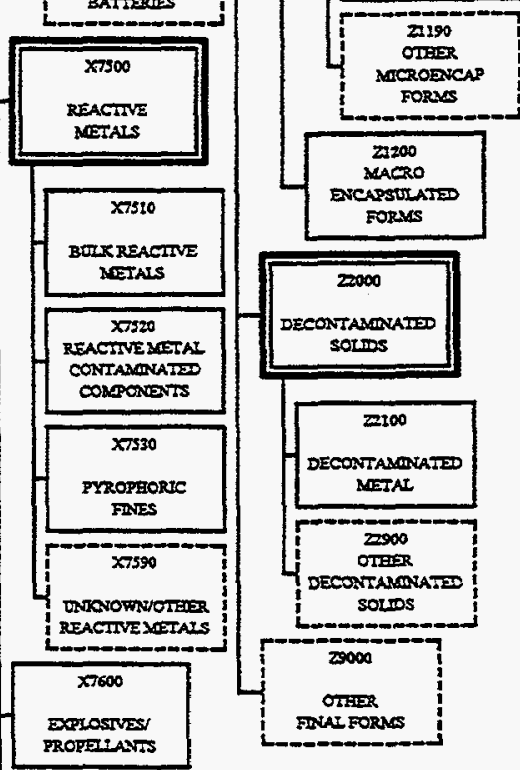


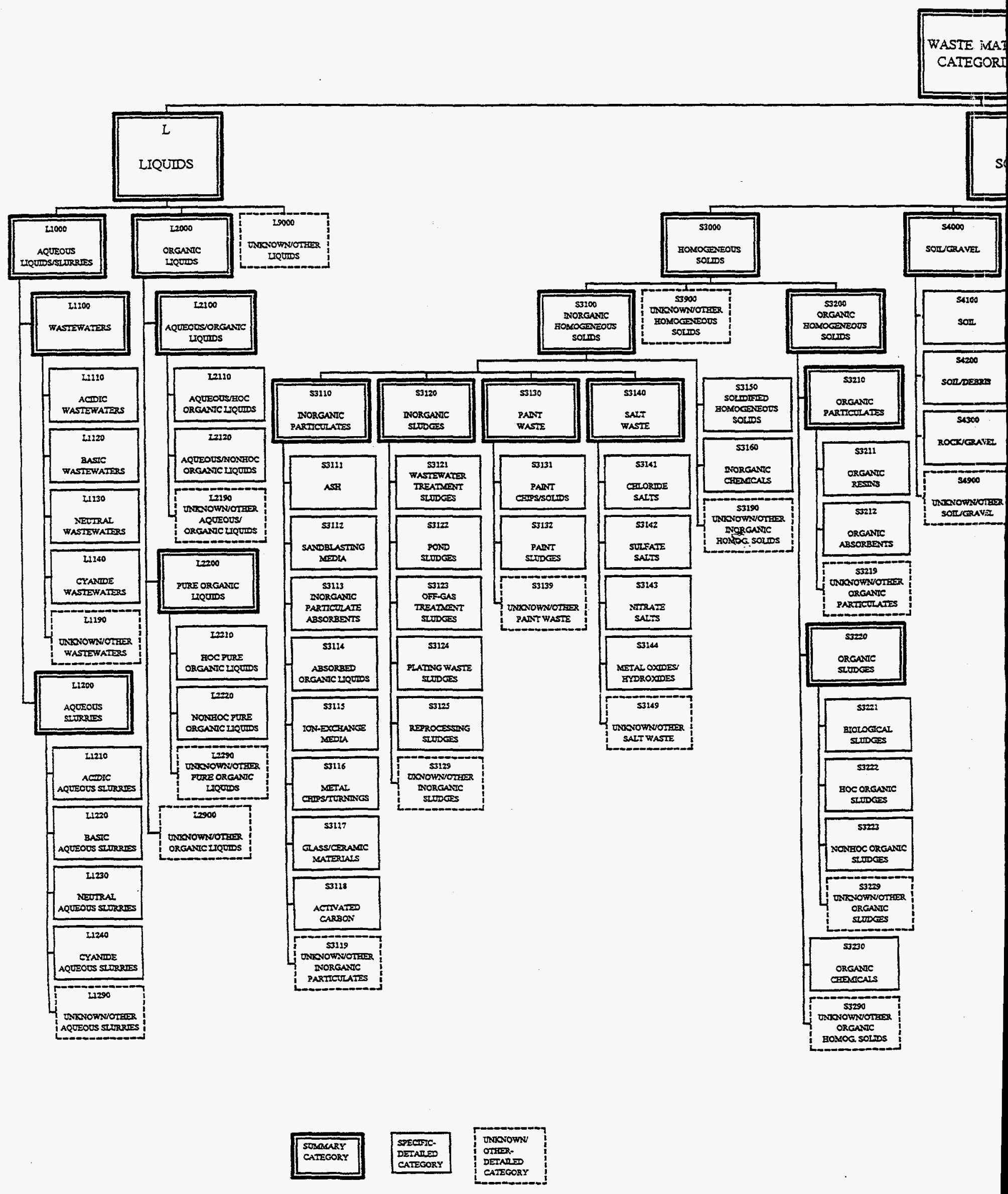


Figure A-3 illustrates the chemical and physical diversity of the Department's waste inventory, while at the same time illustrating the lack of specific characterization data. For example, under category S3110 "Inorganic Particulates" is a subcategory S3114 "Adsorbed Organic Liquids," which indicates the presence of organic waste of unspecified composition adsorbed onto presumably inorganic adsorbant(s), also of unspecified composition and physical form. This sort of information provides but a tenuous basis for waste form/process selection.

The waste breakdown shown in Figure A-3 can be used to put the Department's treatment and disposal problem into perspective when combined with waste volume data. The Department is currently (as of 1995 ) managing $115,477 \mathrm{~m}^{3}$ of MLLW. When combined with inventory data, the MPCs define (albeit grossly) the major waste streams that must be treated for disposal, and the magnitude of the effort that will be required for various wastes with fundamentally different physical and/or chemical properties. Table A-4 shows the Department's MLLW inventory broken out by top-level MPC categories.

Table A-4. MLLW inventory by top-level MPC categories. MPC categories are listed in the form "An***", where $\mathrm{A}$ is a letter, $\mathrm{n}$ is a number, and the *s indicate a roll-up of all categories below An000 in the hierarchy. These data were derived from a comparison of the 1995 Mixed Waste Inventory Report (MWIR) and inventories reported in Site Treatment Plans (STPs).

MPC Codes Description $\quad$ From STP/MWIR $\%$ of total
(1995) Cross-Walk

(cubic meters)

\begin{tabular}{llrr}
\hline L1*** & Aqueous Liquids/Slurries & 5,342 & $4.6 \%$ \\
L2*** & Organic Liquids & 2,166 & $1.9 \%$ \\
L9*** & Unknown/Other Liquids & 5 & $0.0 \%$ \\
S3*** & Homogeneous Solids & 58,007 & $50.2 \%$ \\
S4*** & Soil/Gravel & 12,900 & $11.2 \%$ \\
S5*** & Debris & 34,419 & $29.8 \%$ \\
S9*** & Unknown/Other Solids & 66 & $0.1 \%$ \\
U9*** & Unknown/Other Matrix & 491 & $0.4 \%$ \\
X6*** & Lab Packs & 479 & $0.4 \%$ \\
X7*** & Special & 1,602 & $1.4 \%$ \\
\hline
\end{tabular}

The data from is also shown graphically in Figure A-4. 


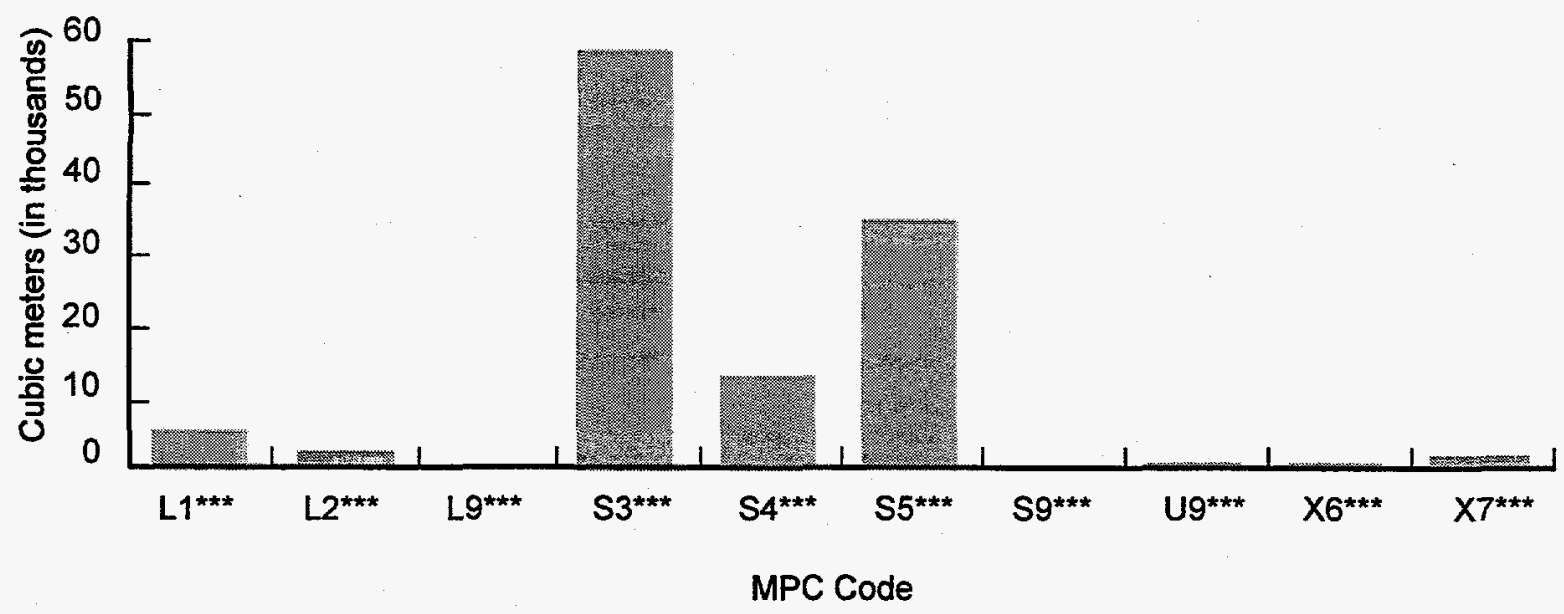

Figure A-4. Graphical representation of MLLW inventory data classified by top-level MPC.

As can be seen from Table A-4 and Figure A-4, over $90 \%$ of the Department's MLLW inventory resides in MPCs $\mathrm{S} 3^{* * *}, \mathrm{~S} 4 * * *$, and $\mathrm{S} 5^{* * *}$. While there is still considerable chemical and physical diversity within these three groupings, a detailed examination of the MPC breakdown in Figure A-3 indicates sufficient similarities to suggest candidate treatment and pretreatment processes, as well as candidate primary and secondary waste forms. While additional data and analysis is needed before final waste forms and treatment processes can be selected, this brief waste inventory analysis suggests a path forward for addressing the bulk of the Department's MLLW treatment and disposal problem. Namely, DOE should invest in waste form/process development to implement the minimum number of treatment systems for MPCs $\mathrm{S} 3^{* * *}, \mathrm{~S} 4^{* * *}$, and $\mathrm{S} 5^{* * *}$. This approach maximizes return on investment by disposing of the bulk of the DOE's MLLW inventory in a timely fashion.

The suggested path forward focuses on MPC categories S3***, S4***, and S5*** (Homogeneous Solids, Soil/Gravel, and Debris), that together comprise over $90 \%$ of the Department's MLLW inventory. By targeting these three MPC categories, the treatment and disposal system should be able to eliminate most of the Department's current inventory. Waste stream composition data from these categories provides an important input to the waste form/process selection process, since each candidate process must be compatible with at least a significant fraction of the waste in these categories. Considering the diversity of the physical and chemical characteristics of the wastes in these three top-level categories, it is unlikely that a single treatment technology will be found suitable for the entire inventory. Systems analysis methodologies can be employed to analyze the trade-offs between implementing a single treatment technology (encompassing both primary and, if necessary, secondary waste forms) or multiple technologies based on such factors as volumes and geographic distribution of the various waste streams; economy of scale; risk, stakeholder, and political issues associated with transportation and disposal; and overall life cycle costs.

The Special Waste category, X7000, constitutes a diverse, sometimes exotic, and always problematic waste category. This category is discussed in a separate section. Because of the unique characteristics of waste streams in this category, specialized waste forms and processes will likely have to be developed to treat the waste for disposal. However, this category represents less than $2 \%$ of the 
Department's total inventory; therefore, the treatment technologies developed for these wastes will be applied only on a very small scale. Because of the small volume involved, it can be argued that these development activities should be assigned a low priority. Even if fully acceptable waste packages are not available for these wastes, it may be possible to dispose of them as nonconforming waste packages because of their small volume, and hence minimal impact on disposal site performance.

\section{A-3.3 Treatment Processes and Products}

The array of waste forms currently under consideration are grouped into four categories based on common materials or processing characteristics:

1. High-temperature waste forms (e.g., glass, ceramic, glass-ceramic, iron-enriched basalt)

2. Hydraulic cements (e.g., Portland-type cements, FUETAP cements, phosphate-bonded ceramics, gypsum-based cements)

3. Encapsulants (e.g., thermoplastics, thermosets)

4. Specialty waste forms (e.g., amalgams).

\section{A-3.3.1 High-Temperature Waste Forms (Glass, Ceramic, Glass-ceramic, Metal)}

The major high-temperature waste forms for immobilizing mixed low-level wastes (MLLW) include glass, ceramics, glass-ceramics, and metals, which are usually processed at $1,000^{\circ} \mathrm{C}$ or higher.

Some common characteristics associated with these high-temperature waste forms and their production processes include:

1. High mechanical strength solids

2. Stable, nondegradable, and chemically durable waste forms

3. Large reduction in waste volume

4. Destruction of organic contaminants

5. Applicability to most inorganic and heterogeneous wastes

6. Difficulty to incorporate volatile elements such as mercury, chlorine, and technetium

7. Extensive offgas treatment systems required

8. Energy intensive.

The attributes of each specific waste form and its production are discussed below. 
A-3.3.1.1 Glass. Glass is the most widely studied high-temperature waste form for waste immobilization. Here, glass usually refers to an inorganic, amorphous, rigid solid with little long-range order. Waste glasses can be further classified into borosilicate, sodalime, high-silica, and phosphate glasses. Some typical compositions of these glasses are shown in Table A-5.

Table A-5. Typical composition ranges of waste glasses (wt\%).

\begin{tabular}{|c|c|c|c|}
\hline Oxide & $\begin{array}{c}\text { Sodalime } \\
\text { (McLellan 1984) }\end{array}$ & $\begin{array}{c}\text { Borosilicate } \\
\text { (Bates 1994; Feng 1988, } \\
\text { 1995; Fu 1994; Hrma 1994; } \\
\text { Li 1996) }\end{array}$ & $\begin{array}{c}\text { Phosphate } \\
\text { (Day 1995; Aloy } \\
\text { 1995) }\end{array}$ \\
\hline $\mathrm{SiO}_{2}$ & $65-75$ & $23-63$ & $0-0.4$ \\
\hline $\mathrm{B}_{2} \mathrm{O}_{3}$ & & $4-22$ & \\
\hline $\mathrm{ZrO}_{2}$ & & $0-13$ & $0-0.1$ \\
\hline $\mathrm{Al}_{2} \mathrm{O}_{3}$ & $1-2$ & $0-20$ & $0-30$ \\
\hline $\mathrm{P}_{2} \mathrm{O}_{5}$ & & $0-3.5$ & $37-63$ \\
\hline $\mathrm{Na}_{2} \mathrm{O}$ & $12-16$ & $0-35$ & $3-27$ \\
\hline $\mathrm{Li}_{2} \mathrm{O}$ & & $0-21$ & $0-8$ \\
\hline $\mathrm{K}_{2} \mathrm{O}$ & $0.1-3$ & $0-8$ & $0-46$ \\
\hline $\mathrm{MgO}$ & $0.1-5$ & $0-19$ & \\
\hline $\mathrm{CaO}$ & $6-12$ & $0-33$ & \\
\hline $\mathrm{CeO}_{2}$ & & $0-10.6$ & $0-2.2$ \\
\hline $\mathrm{Cr}_{2} \mathrm{O}_{3}$ & & $0-2$ & \\
\hline $\mathrm{ZnO}$ & & $0-5$ & \\
\hline $\mathrm{CuO}$ & & $0-6$ & \\
\hline $\mathrm{TiO}_{2}$ & & $0-6$ & \\
\hline $\mathrm{NiO}$ & & $0-2$ & \\
\hline $\mathrm{Fe}_{2} \mathrm{O}_{3}$ & & $0-17$ & $19-38$ \\
\hline $\mathrm{MnO}_{2}$ & & $0-7.4$ & \\
\hline $\mathrm{MoO}_{3}$ & & $0-2.4$ & \\
\hline $\mathrm{PbO}$ & & $0-14$ & \\
\hline$F$ & & $0-17$ & \\
\hline
\end{tabular}


A-3.3.1.1.1 Glass Process Issues-Borosilicate glass has been chosen for immobilizing high-level nuclear waste ( $\mathrm{HLW}$ ) internationally for more than 40 years, and the processing of actual wastes has begun in many countries (Bates et al. 1994). In comparison with HLW, the MLLW is heterogeneous (such as debris) and more refractory for debris and soils. The technology for treating large volume of such heterogeneous MLLW at higher temperature is still in the development stage. Sodalime glass essentially can be produced in the same type of melters where borosilicate glasses are produced. High-silica glass has only limited demonstration for encapsulating slurried liquid wastes. Phosphate glasses have been used to immobilize radioactive wastes in the former Soviet Union (LLNL 1996). The iron-phosphate glass (Day 1995) and the lead-iron phosphate glasses (Chick 1986) were only demonstrated at a very limited laboratory-scale.

\section{Glass Pretreatment, Volatility, Refractory Corrosion, and Devitrification-}

Plasma melting systems usually require much less pretreatment in terms of size reduction, sorting, and separation (Feng 1996b), while electrical melting usually requires certain pretreatment to achieve higher waste loading and technology compatibility for the overall system optimization (Pegg 1994).

Volatility is an important issue for glass making and is dominated by feed preparation and melting technology. Table A-6 shows the volatility measurements for different thermal technologies in producing similar glass products from the same Hanford low-level liquid waste stream (Wilson 1996). The retention of volatile elements of $\mathrm{Cl}, \mathrm{F}, \mathrm{I}$, and $\mathrm{Cs}$ is difficult at high temperature, but it is possible as shown in Table A-6. If dry feeds are used to form a complete cold cap in a joule-heated melter, the volatility of $\mathrm{Cl}$ and $\mathrm{I}$ can be reduced to below $10 \%$ of their original loadings and the volatilization of $\mathrm{F}$ and $\mathrm{Cs}$ can be reduced to below $1 \%$. Proper waste form formulations can also substantially improve the retention of volatile elements, and special formulations for Cs wastes demonstrated over $99 \%$ retention of $\mathrm{Cs}_{2} \mathrm{O}$ during melting of the waste forms containing $35 \mathrm{wt} \% \mathrm{Cs}_{2} \mathrm{O}$ at $1530^{\circ} \mathrm{C}$ (Feng 1995). The available data showed very low retention of $\mathrm{Tc}$ and $\mathrm{Hg}$ in these high-temperature waste forms. If one of these waste forms is selected to treat a waste stream containing significant quantities of such volatile elements, a secondary waste treatment system and waste form will generally be required to immobilize these volatile elements. Volatile elements must be trapped in the off-gas system, then routed to the secondary waste treatment system (operating at low temperature) for stabilization.

Refractory corrosion is a more serious concern associated with phosphate glasses (Chick 1986), and no significant data are available on the refractory corrosion of phosphate glasses in treating wastes at a scale beyond laboratory crucible melting. The cold wall melter is being adopted more widely for waste glass melting where the refractory corrosion can be minimized (Wilson 1996). In general, phosphate glasses are not compatible with current borosilicate glass processing and are more corrosive to the refractory and to the inconel electrodes.

Glass waste forms can devitrify (crystallize) if held at temperatures higher than glass transition temperature for sufficiently long periods. This phenomenon can occur if the glass is reheated after solidification, or if the molten glass is cooled slowly. Because of the low thermal conductivity of most silicate melts, the physical dimensions of the container into which molten waste glass is poured can strongly influence the glass cooling rate, especially near the center of the glass block. For example, the privatization RFP for Hanford LLW waste specifies that the LLW products be packaged in a rectangular metal container $1.8 \mathrm{~m}(\mathrm{~L}) \times 1.2 \mathrm{~m}(\mathrm{~W}) \times 1.2 \mathrm{~m}(\mathrm{H})$. If poured into such a container as a monolith, it is estimated that glass at the center of the container could remain above the glass transition temperature 
(Tg) for up to 1 week if the container is cooled in ambient air. Such a prolonged cool-down would likely result in considerable devitrification. Furthermore, such large glass pours invariably crack during cool-down. Glass may have to be formed as small rapidly quenched drops ("gems") to prevent devitrification. Phosphate glasses are more readily crystallized than silicate glasses and have a narrow phase field for operation ("short" glasses) (Jantzen 1986).

Table A-6. Weight percent loss of selective feed components (Wilson 1996).

\begin{tabular}{lllllllllll}
\hline Technology & Feed & $\mathrm{B}_{2} \mathrm{O}_{3}$ & $\mathrm{Cl}$ & $\mathrm{Cs}_{2} \mathrm{O}$ & $\mathrm{F}$ & $\mathrm{I}$ & $\mathrm{K}_{2} \mathrm{O}$ & $\mathrm{Na}_{2} \mathrm{O}$ & $\mathrm{S}$ & Comment \\
\hline $\begin{array}{l}\text { Gas-fired cyclone } \\
\text { burner }\end{array}$ & slurry & 67 & 87 & 83 & 92 & 94 & 51 & 35 & 51 & $\begin{array}{l}\text { large surface } \\
\text { area }\end{array}$ \\
$\begin{array}{l}\text { Plasma torch-fired, } \\
\text { cupola furnace }\end{array}$ & slurry & 22 & 88 & 84 & 91 & 98 & 48 & 15 & 34 & No cold cap \\
$\begin{array}{l}\text { Electric arc furnace with } \\
\text { top-entering vertical } \\
\text { carbon electrodes }\end{array}$ & dry & $18-51$ & $82-97$ & $39-63$ & $91-99$ & 95 & $25-35$ & $6.5-21$ & $88-94$ & No cold cap \\
$\begin{array}{l}\text { Water jacketed } \\
\text { joule-heated melter with } \\
\text { top-entering } \\
\text { molybdenum electrodes }\end{array}$ & slurry & 14 & 64 & 41 & 15 & 83 & 15 & 13 & 85 & $\begin{array}{l}\text { limited cold } \\
\text { cap and } \\
\text { higher } \\
\text { melting } \\
\text { temp. }\end{array}$ \\
$\begin{array}{l}\text { Ceramic, } \\
\text { refractory-lined, } \\
\text { joule-heated melter with } \\
\text { Inconel plate electrodes }\end{array}$ & slurry & 0 & 48 & 13 & 53 & 82 & 0 & 0 & NA & $\begin{array}{l}\text { partial cold } \\
\text { cap }\end{array}$ \\
$\begin{array}{l}\text { Cold-wall, } \\
\text { ceramic-lined, } \\
\text { joule-heated melter with } \\
\text { molybdenum rod } \\
\text { electrodes }\end{array}$ & dry & 0.1 & $1-13$ & 0.6 & 1 & 10 & 0 & 0 & 53 & $\begin{array}{l}\text { complete } \\
\text { cold cap }\end{array}$ \\
\hline
\end{tabular}

A-3.3.1.1.2 Glass Product Issues-Glass waste forms are usually homogeneous solids with excellent mechanical properties. Waste is usually incorporated into the glass structure as solid solutions, although encapsulating the waste is also possible, such as in the high-silica glass developed at the Catholic University of America (Schulz 1980).

Glasses are noncombustible, do not contain free liquid, do not evolve gases, exhibit extremely low biological activities, and are not degraded by thermal cycling. Reactions with water do occur that can mobilize waste elements, and the reaction rate depends on glass composition. A properly formulated glass usually exhibits low reaction rates. Also, the reactions occur only at the waste form surface, which makes the release rate dependent on the surface area of the waste form. The reactions are complex, involving water diffusion, ion exchange, network hydrolysis, and precipitation of secondary phases (Bates et al. 1994). The secondary phases formed on glass surfaces can affect glass reaction affinity or sometimes inhibit further release of waste elements (Feng 1994a). 
Glass devitrification (crystallization) discussed above partitions radionuclides and hazardous constituents into the various phases that form. Depending on the characteristics of these phases and the radionuclides and hazardous constituents that each phase hosts, the overall release behavior of the waste form can be enhanced or degraded, sometimes by orders of magnitude (Kim 1995; Feng 1994b). One study on HLW glass at Pacific Northwest National Laboratory (PNNL) suggests that a heat treatment on a $\mathrm{HLW}$ glass for 25 hours following a canister centerline cooling schedule produced over 50 vol\% nepheline crystals in the glass. As a result, chromium and boron release rates increased by more than two orders of magnitude ( $\mathrm{Li} \mathrm{1996).} \mathrm{Devitrification} \mathrm{can} \mathrm{also} \mathrm{cause} \mathrm{glass} \mathrm{cracking} \mathrm{and} \mathrm{increase} \mathrm{glass} \mathrm{surface}$ area that can further increase release rates of hazardous elements and radionuclides.

One approach to reduce the tendency towards devitrification and increase retrievability is to produce the final waste form as a multitude of small $(\sim 0.5 \mathrm{~cm}$ to $1.5 \mathrm{~cm})$ bodies. The small size of the final waste forms facilitates rapid cooling of the final product. When these gems are loaded into containers, a certain fraction of the container volume is left empty because of the packing arrangement of the small bodies, thereby decreasing the bulk density and volume reduction resulting from the process.

The solubilities of certain elements (called troublesome elements) in glasses are very limited as shown in Table A-7, and these solubilities impose a limit on waste loading and processability of certain MLLW. These solubilities are defined as the amount of the elements in glass that do not cause substantial crystallization and result in the glass remaining clear when cooled to room temperature ( $\mathrm{Li}$ 1995). The reported solubilities in Table A-7 are a strong function of glass composition, melting temperature, and redox conditions of the melts. The actual retention of these elements in glass is mainly determined by the processing technology, as shown in Table A-6, where cold cap formation is the key to higher retention. The amounts of the troublesome elements retained in glasses can be much higher than solubility limits listed in Table A-7 if opaque glass is allowed (Feng et al. 1996b, 1996c). The mutual interaction between these troublesome elements may also substantially decrease their retention in glasses (Li 1995b, 1996).

High processing temperatures can be useful for destroying organic compounds in the waste feed stream. However, high concentrations of organics can affect the redox state of the waste form. The redox state of waste forms is characterized by the ratio of $\mathrm{Fe}$ (II)/Fe(III) (Schreiber 1995) and is known to affect chemical durability and viscosity (Feng 1988), solubilities of metals and some minor components (Li 1996), and liquidus temperatures. Waste streams containing large quantities of organics are usually best pretreated by an incineration process to reduce the carbon content of the stream feeding the high-temperature process.

A-3.3.1.1.3 Comparison of Different Glass Systems-Borosilicate and sodalime glasses may be used to treat most of the DOE MLLW because of the matured technology, good chemical durability, and higher solubilities for most waste components. Sodalime glass may have certain advantages in terms of better product durability, lower volatility, and higher waste loading when treating wastes with high calcium content, such as soils and calcined wastes. Phosphate glasses, especially those with lower melting temperature, may be useful for treating special wastes with high contents of $\mathrm{Cs}$, Tc, and $F$. 
Table A-7. Approximate solubilities of troublesome elements in silicate waste glasses (wt\%).

\begin{tabular}{|c|c|c|c|c|c|c|c|c|c|}
\hline Element & $\mathrm{I}^{\mathrm{a}}$ & $\mathrm{Cl}^{\mathrm{b}}$ & $\mathrm{F}^{\mathrm{c}}$ & $S^{b}$ & $P^{d}$ & $\mathrm{Ni}^{\mathrm{d}}$ & $\mathrm{Cr}^{\mathrm{d}}$ & $\mathrm{Hg}^{\mathrm{e}}$ & $A s^{e}$ \\
\hline Solubility & 0.1 & 0.57 & 3.4 & 0.75 & 5.7 & 3 & 1.1 & 0.1 & $1-3$ \\
\hline \multicolumn{10}{|c|}{$\begin{array}{l}\text { a. Wilson } 1996 . \\
\text { b. Li 1995a. } \\
\text { c. Li } 1996 . \\
\text { d. Li } 1995 \text { b. } \\
\text { e. Volf } 1984 \text {. }\end{array}$} \\
\hline
\end{tabular}

A-3.3.1.2 Ceramics. A ceramic waste form is an assemblage of mineral phases, into which the radionuclides and hazardous elements are incorporated as solid solutions. The rationale behind the ceramic waste forms is that certain mineral phases containing radioactive elements exist in nature for billions of years, and some of them are in contact with water for a considerable portion of that time.

Various ceramic waste forms have been proposed for immobilizing HLW and include synroc, rutile, monazite, and sodium zirconium phosphate. In general, the production of these ceramic waste forms involves high-temperature and high-pressure processes, which increases the production cost. The processes are more difficult to scale up than a glass-making process for handling the huge amounts of MLLW. The requirements on the feeding materials for producing ceramic waste forms are usually more restrictive and are less suitable for the heterogeneous MLLW. The solid solutions in these minerals are not as flexible as glass to accommodate the broad range of radionuclides and hazardous components existing in MLLW. Therefore, very little information is available for using ceramic waste forms for treating MLLW.

A-3.3.1.3 Glass-Ceramic Waste Forms. Glass-ceramics such as vitreous ceramics are composed of various metal-oxide crystalline phases embedded in a silicate-glass matrix. Glass is an amorphous solid. The main difference between vitreous ceramics and glasses is the presence or lack of crystals. All waste forms are made of three groups of components: "structure-making" components such as $\mathrm{SiO}_{2}$, $\mathrm{Al}_{2} \mathrm{O}_{3}, \mathrm{ZrO}_{2}$; "fluxes" such as alkalis and boron; and "intermediates" or crystal-formers such as $\mathrm{Fe}, \mathrm{Ni}$, and $\mathrm{Cr}$ oxides.

To form a durable and processable glass, sufficient structure-making components have to be included to achieve good chemical durability; sufficient fluxes have to be included to obtain a reasonable operating temperature; and intermediates are limited to their solubility limits in glass. For instance, the solubilities for $\mathrm{Cr}$ and $\mathrm{Ni}$ oxides are usually less than 2 and $4 \%$, respectively. These requirements limit the applicability of glass for high-metal content wastes (i.e., at economical waste loading). Vitreous ceramics can accept more structure-making components (usually contained in contaminated soils) than a glass can, because they usually melt at higher temperature. Vitreous ceramics can accept more intermediates (metal-rich wastes) than glass can because they encourage the formation of crystalline phases of these metal oxides, but they usually accept fewer fluxes (high alkali wastes).

Vitreous ceramics are more suitable for waste streams with high-metal content and low fluxes, while glasses are a better choice for waste streams with low metal content and sufficient fluxes. 
Therefore, the vitreous ceramic waste forms will encompass a different composition region (or an envelope) than that of homogeneous glass waste forms.

The durability of glass is determined mainly by the relative amount of structure-making elements of $\mathrm{SiO}_{2}$ and $\mathrm{Al}_{2} \mathrm{O}_{3}$ to the total alkalis. Glasses with more silica and alumina and less alkalis are usually more durable. The durability of glassy phases in vitreous ceramic is determined by the same factor as in glass, but the glassy phase can usually have much higher $\mathrm{SiO}_{2}$ and $\mathrm{Al}_{2} \mathrm{O}_{3}$ and far less alkalis than normal glasses because controlled crystallization only removes non-silicon elements to form crystals, and silica and alumina are enriched substantially in a glassy matrix (Feng 1994b). The glassy phases in vitreous ceramics can, therefore, be made more durable than normal glasses. The crystal phases in vitreous ceramics, such as $\mathrm{Ca}_{3}\left(\mathrm{PO}_{4}\right)_{2}$, magnetite $\left(\mathrm{Fe}^{2+} \mathrm{Ni}, \mathrm{Mn}\right) \mathrm{Fe}^{3+} 2 \mathrm{O}_{4}$, hibonite $\mathrm{Ca}(\mathrm{Al}, \mathrm{Fe}, \mathrm{Zr}, \mathrm{Cr})_{12} \mathrm{O}_{19}$, baddeleyite $\mathrm{ZrO}_{2}$, zirconolite $\mathrm{CaZrTi}_{2} \mathrm{O}_{7}$, and corundum $\mathrm{Al}_{2} \mathrm{O}_{3}$, are more stable thermodynamically than parent glasses and also less soluble in water than glasses. Therefore, vitreous ceramics can be made more durable than a glass with the same composition.

Glass is expected to be suitable for treating over $70 \%$ of the DOE MLLW, while vitreous ceramic may be best for only $20 \%$ of the DOE MLLW. Usage of both glass and vitreous ceramic waste forms will make vitrification technology applicable to the treatment of more than $90 \%$ of the DOE MLLW.

Glass-ceramics are partially crystalline materials formed by controlled devitrification of glass (Hayward 1988). These types of waste forms include talc-silicon glass-ceramic (TSGC) (Vinjamuri 1993), iron-enriched basalt (IEB) (Reimann 1992), and vitreous ceramics (Feng 1994b, 1995). The composition ranges for these three waste forms are shown in Table A-8. The devitrification is controlled in such a way that most radionuclides and hazardous elements are incorporated in the crystalline phases, and the network formers such as silica and alumina and any other components that do not dissolve into the crystalline solid solutions remain in the glassy matrix (Feng 1994b). Glass ceramics are, therefore, thermodynamically more stable and usually more durable than the parent glass (Feng 1994c).

The TSGC was developed for immobilizing fluorine-sodium blend calcine waste. The waste loading is up to $70 \mathrm{wt} \%$; the density is high (up to $3.23 \mathrm{~g} / \mathrm{cm}^{3}$ ); and the chemical durability is acceptable (less than $1 \mathrm{~g} / \mathrm{m}^{2}$-day in a 14-day MCC-1 test for the TSGC with $2 \mathrm{wt} \%$ of metallic aluminum). However, the process is very complex, including precalcination, powder handling equipment, and hot pressing, and the durability for $70 \mathrm{wt} \%$ fluorine-sodium is quite low (from 0.37 to $32.59 \mathrm{~g} / \mathrm{m}^{2}$-day). The suitability of processing large volume of heterogeneous MLLW has not been demonstrated.

The IEB can be processed in a conventional joule-heated melter, although it requires a processing temperature between 1,400 and $1,600^{\circ} \mathrm{C}$ (Reimann 1992). It should also be processable in plasma melters. The waste form has good chemical durability with a uranium release rate of about 0.006 $\mathrm{g} / \mathrm{m}^{2}$-day, and the waste loading can be over $90 \%$. This waste form should be well suited for treating wastes with high iron contents. The volatility of $\mathrm{Cs}$ is high due to the high processing temperature.

Vitreous ceramics are similar to IEB, except they cover a much broader composition range than TSGC and IEB waste forms (Table A-8), and the waste loading is usually more than $90 \%$. It can also be processed at temperature ranges between 1,000 and $1,600^{\circ} \mathrm{C}$ through conventional joule-heated melters and plasma melters (MSE 1994; Feng 1994d). Heterogeneous MLLW can be fed directly into a plasma furnace for the production of vitreous ceramics without size reduction (55-gal drums can be fed directly), 
separation, or drying. The melting process is the same as production of a glass waste form, except that the poured waste form needs an additional heat-treatment step to promote crystal formation in the vitreous ceramics. The additional heat treatment step can be carried out by utilizing the residual heat itself after the waste form is poured into a container, or the waste form can be heat-treated in a second industrial furnace.

Crystal formation is the preferred process in vitreous ceramics and it can be called beneficial crystallization. The controlled crystallization in vitreous ceramics produces durable crystals such as zirconalite, perovskite, spinel, feldspar, etc., that are stable and durable in aqueous environments. The controlled crystallization also produces a glassy matrix that is high in silica and alumina and is extremely durable (Feng 1994b). Vitreous ceramics have been tested with extended long-term PCT and vapor hydration tests, and all the results suggest greater durability than $\mathrm{HLW}$ glasses, with uranium releases as low as $0.000029 \mathrm{~g} / \mathrm{m}^{2} /$ day (Feng 1994c). The volatility of Cs in the process is high, but a special formulation of nepheline-vitreous ceramics for treating Cs wastes showed less than $1 \% \mathrm{Cs}_{2} \mathrm{O}$ loss after melting the vitreous ceramic, with $35 \mathrm{wt} \% \mathrm{Cs}_{2} \mathrm{O}$ contents at $1,550^{\circ} \mathrm{C}$.

Table A-8. Composition ranges of glass-ceramic waste forms.

\begin{tabular}{|c|c|c|c|c|}
\hline Oxide & $\begin{array}{l}\text { Talc-Silicon } \\
\text { Glass-Ceramic } \\
\text { (Vinjamuri 1993) }\end{array}$ & $\begin{array}{l}\text { Iron-Enriched } \\
\text { Basalt } \\
\text { (Reimann 1992) }\end{array}$ & $\begin{array}{l}\text { Vitreous Ceramic } \\
\text { (Feng 1994c, 1995) }\end{array}$ & $\begin{array}{l}\text { In Situ Vitrification } \\
\text { Waste Form } \\
\text { (Timmons 1996) }\end{array}$ \\
\hline $\mathrm{SiO}_{2}$ & $24-34$ & $35-57$ & $11-65$ & $55-85$ \\
\hline $\mathrm{B}_{2} \mathrm{O}_{3}$ & 3 & & & \\
\hline $\mathrm{ZrO}_{2}$ & 12 & $0-14$ & $0-17$ & \\
\hline $\mathrm{Al}_{2} \mathrm{O}_{3}$ & $5-16$ & 8-17 & $0-40$ & $3-13$ \\
\hline $\mathrm{P}_{2} \mathrm{O}_{5}$ & 0.2 & & $0-27$ & $0-1$ \\
\hline $\mathrm{Na}_{2} \mathrm{O}$ & 4 & $0-7$ & $1-28$ & $1-5$ \\
\hline $\mathrm{Li}_{2} \mathrm{O}$ & & $0-4$ & $0-10$ & \\
\hline $\mathrm{K}_{2} \mathrm{O}$ & 1 & $0-7$ & $0-28$ & $0-2$ \\
\hline $\mathrm{MgO}$ & & $0-10$ & $0-16$ & $0-2$ \\
\hline $\mathrm{CaO}$ & $8-20$ & $0-18$ & $0-50$ & $2-20$ \\
\hline $\mathrm{CeO}_{2}$ & 1 & & $0-20$ & $0-2$ \\
\hline $\mathrm{Cr}_{2} \mathrm{O}_{3}$ & 1 & $0-10$ & $0-15$ & $0-1$ \\
\hline $\mathrm{ZnO}$ & & & $0-22$ & \\
\hline $\mathrm{CuO}$ & & & $0-21$ & \\
\hline $\mathrm{TiO}_{2}$ & & & $0-30$ & $0-1$ \\
\hline $\mathrm{NiO}$ & & & $0-15$ & \\
\hline
\end{tabular}


Table A-8. (continued).

\begin{tabular}{lllll}
\hline Oxide & $\begin{array}{l}\text { Talc-Silicon } \\
\text { Glass-Ceramic } \\
\text { (Vinjamuri 1993) }\end{array}$ & $\begin{array}{l}\text { Iron-Enriched } \\
\text { Basalt } \\
\text { (Reimann 1992) }\end{array}$ & $\begin{array}{l}\text { Vitreous Ceramic } \\
\text { (Feng 1994c, 1995) }\end{array}$ & $\begin{array}{l}\text { In Situ Vitrification } \\
\text { Waste Form } \\
\text { (Timmons 1996) }\end{array}$ \\
\hline $\mathrm{Fe}_{2} \mathrm{O}_{3}$ & 1 & $10-35$ & $0-85$ & $0-6$ \\
$\mathrm{MnO}_{2}$ & & $0-10$ & & $0-1$ \\
$\mathrm{MoO}_{3}$ & & & $0-2$ & $0-12$ \\
$\mathrm{PbO}$ & $1-10$ & $0-12$ & \\
$\mathrm{~F}$ & & 0 & \\
\hline
\end{tabular}

A-3.3.1.4 Issues Related to In Situ Vitrification Waste Forms. In situ vitrification (ISV) is a mobile thermal treatment technology being developed and deployed to remediate soil contaminated with hazardous waste and radionuclides. The process was invented in 1980 by PNNL for treating transuranic-contaminated soils (Buelt 1987) and has been commercialized by Geosafe Corporation (Timmons 1996).

The waste form produced from ISV process is a glassy product that can be either a glass or a glass-ceramic. All the property and processing issues discussed in Section 3.3.1.1.1 and 3.3.1.1.2 should also be applied to the ISV waste form. There are, however, some unique features associated with ISV waste forms because of the unique ISV processing and the specific targeted waste compositions.

A-3.3.1.4.1 ISV Waste Form Composition-In most of the ISV processes, the waste form composition is determined solely from the composition of the contaminated soils. The waste form composition cannot easily be adjusted because of the nature of the ISV process. A typical ISV waste form composition range is shown in Table A-8. The unique features of this composition range include (a) high $\mathrm{SiO} 2$ content of 55 to $85 \%$ and (b) low alkali (and boron) content of 1 to $5 \%$. This is why the melting temperature in the ISV process is usually in the range of 1,500 to $2,000^{\circ} \mathrm{C}$ (Peterson 1992; Tixier 1994). The volume reduction in such a soil treatment is $20-50 \%$. The waste form is usually more durable than typical borosilicate glasses due to its high content of silica and low content of alkalis.

The high melting temperature of the ISV process offers high degree of organic destruction of 99.99 to $99.999999 \%$. The high processing temperature also results in low retention of volatile materials such as Cs and halides and the Cs retention was reported to be 0.12 to $2.3 \%$ (Tixier 1994). The large depth of molten glass pool (processing depth up to 20 feet) can increase the retention of some volatile elements.

Melter corrosion is not an issue in the ISV process because only graphite electrodes are in contact with the melting glass during processing. Viscosity of the waste form is usually not a major concern because of the ability to achieve a high melting temperature (up to $2,000^{\circ} \mathrm{C}$ ) during ISV process. However, the electrical conductivity of the melt is more of a concern for treating highly leached clay soils or sandy soils and the addition of alkalis may be required for treating such soils (Shade 1990). Another composition concern may be encountered when treating soils mainly consisting of limestones 
because (a) there may not be enough silica and alumina to form a durable ISV product, and (b) the low melting temperature of limestone soil may leave steel and other metal debris unmelted to cause a short circuit between the electrodes. Soil composition analysis is required to identify such problems and mitigate the concern with addition of silica rich soils or sands to improve the product quality by raising the melting temperature above the melting point of the metal debris.

A-3.3.1.4.2 Devitrification of ISV Waste Forms-Full-scale ISV is performed in multiple sequential melt batches producing large pools (typically 500 to 1,000 tons per batch). The molten product is isolated in the low thermal conductivity soil and can be maintained at temperatures above the glass transition temperature for months. This slow cooling promotes devitrification, and as a result, the ISV product is almost always highly opaque (Timmons 1996). The extent of devitrification depends on the melt composition and thermal history. The ISV waste form can be more properly called glass ceramics instead of glass because of the high degree of crystallinity. The crystallization of the ISV waste form also introduces cracking, which increases the surface area of the product. However, the extent of cracking is usually very limited due to the extremely slow cooling (Timmons 1996).

Durability studies on the devitrified ISV waste forms have shown that the devitrified products do not adversely affect the chemical durability (Lokken 1982, Timmons 1996). This is probably because the formation of diopside and wollastonite crystals during devitrification decreases the concentration of $\mathrm{CaO}$ while increasing the concentration of $\mathrm{SiO}_{2}$ in the residual glassy phase for silica-rich soils. The formation of cristobalite was also observed in the ISV waste form, resulting in a decreased $\mathrm{SiO}_{2}$ concentration in the glassy phase. The silica content in the residual glassy matrix was still much higher than typical borosilicate glasses because of its initial high silica content (up to $85 \mathrm{wt} \%$ ). The ISV product from treating such high silica soils is almost always very durable (Timmons 1996).

Therefore, devitrification of the ISV waste form is not a concern for treating high-silica soils, but it can be devastating for treating limestone-rich soils. Any formation of diopside, wallastonite, and cristobalite in the ISV waste form from treating limestone soils will deplete the silica content of the residual glass, leaving behind a weak and water soluble glassy phase that is rich in $\mathrm{CaO}$. Similarly, the formation of nepheline-type of crystals is also very likely if the ISV process is to be used to treat sodium rich wastes, because the ISV product is always subjected to conditions favoring crystallization. This devitrification behavior may severely limit the applicability of ISV for treating wastes rich in alkalis and alkaline earth elements.

A-3.3.1.5 Metal Waste Forms. There have been many studies of metal waste forms for immobilizing HLW (Jardine 1978) and spent nuclear fuels (Battles et al. 1994; Ackerman, Johnson, and Laidler 1994). Materials studied include iron-zirconium alloys, copper alloys, aluminum alloys, low-alloy steels, austenitic and ferritic stainless steels, and nickel alloys. These metal waste forms offer ease of fabrication and potential resistance to groundwater attack.

In the treatment of MLLW, the major metal waste forms are formed as reduced metals separated from the bottoms of vitrifiers and the metal waste forms produced in the molten metal technology treatment systems. These metals are usually slightly radioactive and are difficult to recycle. There is very little data available on the durability of the metal waste forms, especially regarding the long-term durability. The low-alloy steel types of metal waste forms are especially a concern because experience shows that unprotected metal equipment and tools left in the field disintegrate or disappear completely in 
just a few years. This means there is a potential release of the hazardous and radioactive elements from the metal waste forms into the environment again in just a few years.

When the metal wastes are completely oxidized with limited additives such as soils in a plasma melter, they can be converted into a durable vitreous ceramic waste form (Feng 1994d, MSE 1994).

A-3.3.1.6 Technical Deficiencies. More work is needed on: (a) low-temperature waste forms for immobilizing the volatile secondary wastes generated during vitrification; (b) devitrification study of glasses under both ex situ and in situ conditions; (c) better understanding of the crystallization process in vitreous ceramics; (d) understanding, developing, and optimizing the test methodology to evaluate the durability of multiple-phase waste forms; (e) investigating the partition of radionuclides and hazardous elements in multiple phase waste forms; and (6) the aging effects on waste form durability, especially for metal waste forms.

\section{A-3.3.2 Hydraulic Cements}

A-3.3.2.1 Introduction. Cementitious immobilization of biologically hazardous elements and compounds offers several advantages relative to alternative technologies: (a) the technology is readily available and an extensive application history exists; (b) the waste form processing involves only ambient temperatures and pressures which offers both energy and safety advantages; (c) the materials needed are readily available at low cost; (d) studies throughout the world have firmly documented the applicability of cementitous formulations to immobilize hazardous materials; and finally (e) relative to glasses, the hydroxylated matrix materials have the advantage of being in near-thermodynamic equilibrium with potential ultimate disposal environments (repositories).

\section{A-3.3.2.2 Background}

A-3.3.2.2.1 Classification of Cementitious Waste Form Matrices-Hydraulic cement disposal systems are commonly based on the chemistry and hydration of Portland cement (Roy 1990). Post (1981) and a panel of other scientists had developed an independent weighted rating scheme for waste forms, in which cementitious waste forms out-performed all other forms of glass and ceramic waste forms. Ordinary Portland cement (OPC) is widely available and all first world countries regulate this material to strict quality standards. The fact that the American Society for Testing and Materials (ASTM) has specifications for Portland cement manufacture means that cements produced anywhere within the U.S. will behave the same. The consequences of these standards is a low-cost construction material that comprises a 1.65 trillion dollar investment in the infrastructure of the United State alone.

Alteration mechanisms of Portland cement are well understood. Degradation of Portland cement occurs via ingress and egress of ions and liquids through the surface via the pore system of the hardened cement. Several ways to eliminate this problem have been developed. These include polymer impregnated concrete (PIC), polymer cement concretes (PCC) and polymer concretes (PC) (Grosskurth 1991). The first of these impregnates the open porosity of the hardened cementitious body with liquid monomers which, after penetration, are then cross-linked via heat or radiation. Waste forms of this type perform exceptionally well against ingress of deleterious agents and leaching, but the durability of the polymeric system is limited by the stability of the polymer. Impregnation with aqueous alkali silicate coatings (inorganic polymers) offers significant advantages over organic polymers and contributes to the 
formation of additional calcium-silicate-hydrate (C-S-H) within the pore structure (Silsbee and Scheetz 1996). Similarly, surface impregnation with polymeric sulfur has been demonstrated. Polymer cement concretes and polymer concretes are more accurately described as Portland cement- and aggregate-filled polymers, respectively. The principal matrix in PCC and PC is the polymer, not hydrated Portland cement. Although some marginal advantage is achieved by the use of Portland cement fillers as they hydrate in the presence of limited water in these systems, they represent a rather expensive filler.

Cementitious systems not based on OPC are also relatively common in the construction industry, but less so as host matrices for wastes. Calcium aluminate cements have received modest attention and have some potential advantages based on thermodynamic compatibility with certain types of wastes (Roy et al. 1982; Barnes et al. 1982; Scheetz et al. 1985; Roy et al. 1980). Another class of hydraulic cements rely upon an acid/base reaction (Wilson and Nicholson 1993). The most common of these are Sorrel cements, which set to a matrix composed of crystalline magnesium oxychloride. The various metal oxide/phosphoric acid cements are also in this group; all of which have little or no research support for waste forms. Finally, several recent publications have dealt with alkali-activated cements (AAC) (Jiang et al. 1993; Roy and Silsbee 1991) as host waste forms for sodium-rich wastes. The chemistry of AAC relies upon high $\mathrm{pH}$ to initiate pozzolanic reactions in aluminosilicate substrates to form monolithic solids. Commercialization of the concept has occurred (Davidovits, Comrie, and Paterson 1990), although the product has not yet caught on in the market place. The hydration of alkali-activated cements results in x-ray amorphous precursors to zeolites and clays that show good retention of radionuclides and hazardous elements.

A-3.3.2.2.2 Mechanisms of Degradation-Performance of cementitious waste forms is impacted by both extrinsic and intrinsic factors. Extrinsic alteration agents must transport ions and/or solutions into the waste form to degrade performance. Entrance is gained via the pore structure of the matrix. Intrinsic affects involve deleterious chemical or physical interactions between encapsulated wastes and the cementitious matrix. Examples of degradation of Portland cement-based waste forms by external agents include: sulfate attack in the presence of calcium; sulfate attack in the presence of magnesium; sulfate attack in the presence of sodium; formation of Freidel's salt from chloride attack; and leaching of Portlandite (Walton, Plansky, and Smith 1990; Roy and Scheetz 1993; Esh and Scheetz 1995; Esh 1994; Lee, Roy, and Scheetz 1994; Lee 1993; Snyder, Clifton, and Pommersheim 1996). Oxygen diffusion into the waste form can alter Eh (oxidation potential) control of poly-valent leachability (Atkinson et al. 1985, 1988, 1989a,b). Control over the total porosity of the waste form and especially the pore size distribution will minimize release. Examples of intrinsic degradation of Portland cement-based waste forms include exchange of calcium from the matrix by ion exchange resins, swelling of encapsulated exchange resins, and excessive heat buildup. Radiolysis of water in cementitious waste forms has been evaluated several times since the mid-1970s with the consensus that there is apt to be little effect unless the waste form has a high content of organic materials (Moore 1981; McDaniel and Delzer 1988; Dole et al. 1983; Muraoka et al. 1983, 1985). An area that has received some study is the effects of biological agents on the stability of cement. In situations where sufficient "food" is available, bacterial action can result in the formation of mineral acids corrosive to cementitious matrix materials.(Rodgers et al. 1993a,b, 1996; Sand, Brock, and White 1984; Wierig 1983, Libert et al. 1993; Hamilton et al. 1996). Although the NRC has required ASTM testing for fungal and bacterial stability of waste forms for years, the protocol may not include the appropriate group of bacteria. One reported industrial explosion and fire in 1970 in Edinburgh has been attributed to concrete failure of chemical 
storage tanks caused by attack of a sulpho-vibrio group of bacteria (Godfrey 1990). However, degradation by this means is considered unlikely in realistic waste disposal scenarios (Rushbrook 1985).

\section{A-3.3.2.2.3 Limitations to the Use of Cementitious Host Matrices.}

Portland Cement-Based. The principal limitation to the use of OPC-based host matrix for MLLW waste lies in its inability to retain certain common ions, specifically nitrate $\left(\mathrm{NO}_{3}\right)$ and alkali ions. Crystal chemical substitution of these ions into any of the minerals resulting from Portland cement hydration reactions is not favored. Very little nitrate or alkali can be substituted, leaving them readily accessible to external leach solutions. Modification to the bulk host matrices encourages the formation of feldspathoid minerals (also classified by some mineralogists as zeolites) related to sodalite, but substitution is typically limited to one mole of nitrate per mole of mineral (at most a few weight percent), which is not very efficient in retaining large quantities. Some alkali can be substituted and retained, but as with the case of nitrate, very little. The presence of certain elements and organic compounds have adverse effects on the setting behavior of Portland cements. Boron, in even small concentration, can retard the setting of Portland cements. By contrast, calcium chloride is routinely used in cold weather concreting to accelerate the setting behavior. Sugars and some amides are known to be set retarders. These effects are concentration dependent and in some cases the effects are reversed at different concentrations. As an example, calcium chloride, calcium sulfate, sodium hydroxide, lead, copper, and tin salts, amines and hexachlorobenzene all exhibit this reversal phenomenon (Conner 1990).

Alkali-Activated Cements. An alternative to Portland cement was developed to address just this question of the alkali content. The so-called alkali-activated cements (AAC) utilized aluminosilicate materials as the framework formers and the high $\mathrm{pH}$, associated with alkali hydroxides, to stimulate the pozzolanic reactions (Gougar et al. 1996a,b). Examples of the aluminosilicate materials include blast furnace slags, fly ash, and even bentonitic soils. A potential limitation to the use of AAC in some situations is rapid uncontrolled setting behavior; not unlike the behavior of Portland cement with improper levels of sulfate admixtures. One way to prevent so-called "flash setting" is to avoid the use of high $\mathrm{pH}$ agents in the initial mix. The advantage of this approach will be manifested in enhanced processing of the waste form. Once the AAC waste mixture has been transferred into the canister, setting can be initiated by a mild electric field (Young et al. 1995; Barbston and Malone 1993).

\section{A-3.3.2.3 Applications}

A-3.3.2.3.1 Proprietary Private Sector Cement-based Processes. More than 50 commercial solidification processes can be identified for the immobilization of both industrial and nuclear wastes (Conner 1990). Only $15 \%$ of these processes are specifically intended for the stabilization of nuclear waste materials. The majority of the reported processes are based upon a Portland cement matrix or one modified with lime, clay, aqueous silicate, or fly ash. The remainder of the approaches rely on lime, lime/fly ash, or lime/cement kiln dust mixture. One process, which is no longer available, was based on a plaster-of-Paris (calcium sulfate) matrix. All of the identified processes have been demonstrated. They can further be classified into processes that are mobile or operated from a fixed facility; some processes can be accomplished either way. Varying amounts of detail are available on these processes because many of them are proprietary. Chem-Nuclear Systems (CNS) is the largest of the nuclear waste vendors operating a Portland cement-based solidification approach. It uses proprietary 
additives tailored to specific waste streams, and both mobile and fixed processing facilities. Chem-Nuclear operates the very successful Barnwell, South Carolina disposal facility.

British Nuclear Fuels (BNFL) is the United Kingdom equivalent of CNS. By 1998, they will have solidified all of the UK's forty year backlog of LLW and intermediate-level waste (ILW) with inorganic cements. ${ }^{2}$ Some of the ILW is considerably more radioactive (up to $500 \mathrm{watts} / \mathrm{m}^{3}$ and $20,000 \mathrm{nCi} / \mathrm{g}$ TRU) than is U.S. defense-type HLW. BNFL's formulations are primarily based on granulated blast furnace slag and Portland cement (Palmer and Fairhall 1993; Heafield and Barlow 1988; Palmer 1990; Fairhall and Palmer 1987). Delaware Custom Materials (DCM) is an exception to the scarcity of information (Hoffer 1988; Scheetz and Hoffer 1996). ${ }^{b}$ This process is a Portland cement/aqueous silicate system which relies upon the alkali silicate activation of Portland cement to regulate the setting behavior and resulting physical properties of the waste form. It has been used in a fixed processing facility mode as in the case of the continuous solidification of approximately one million gallons of uranium-containing sludge. In routine use, the process is based upon self-contained 55-gal drums (although not limited to that size) with an internal mixer. The process, like most others, is versatile with respect to the type of wastes which can be solidified, including exchange resin, boron-rich evaporator bottoms, heavy metals, oils, detergents and other organic solvents. The flexibility of the system allows for the tailoring of the formulation to the waste stream. The DCM process has been used at the Idaho National Engineering Laboratory (INEL) and laboratory tests have demonstrated the solidification of Naval Reactor Facility wastes with the compositions listed in Table A-9.

Table A-9. Naval Reactor Facility waste (simulated).

\begin{tabular}{lc}
\hline \multicolumn{1}{c}{ compound } & $\begin{array}{c}\text { range of concentration } \\
(\mathrm{ppm})\end{array}$ \\
\hline ammonium persulfate & $10,000-20,000$ \\
ammonium & $50,000-100,00$ \\
ethylenediamine & $15,000-30,000$ \\
ethylenediamine tetracetic acid & $40,000-150,000$ \\
thiourea & $5,000-20,000$ \\
hydrazine & trace -100 \\
metals $(\mathrm{Cu}, \mathrm{Ni}, \mathrm{Fe})$ & trace- 10,000 \\
\hline
\end{tabular}

A-3.3.2.3.2 Government Laboratory Based Processes. Oak Ridge National Laboratory (ORNL) developed a batch processing approach dubbed FUETAP, Formed Under Elevated Temperature and Pressure. The process received considerable attention in the pre-1983 waste form development era. The process relied upon an autoclaving step to accelerate the hydration reactions of the Portland
a. Fairhall, Graham A. 1996, personal communication.
b. Delaware Custom Materials, 1996, personal communication with John Hayes. 
cement-based matrix. The initial process, as reported by Moore et al. $(1981,1983)$, was based on a fly ash/clay formulation with a very high water to cement ratio, which necessitated an additional field operation to post-dry the cured product before final closure. These formulations were based upon ongoing research at ORNL and were closely linked to the hydrofracturing program. If the fundamental concept of the FUETAP process is considered with modifications to other waste streams, it is a viable technology. The INEL has successfully evaluated alkali activated cements (AAC) in bench-scale tests to convert HLW to "intermediate" waste forms, which could then be converted to a glass-ceramic via Hot Isostatic Processing (HIPping) or perhaps by direct melting. (Gougar et al. 1996a,b; Siemer et al. 1996). AAC, discussed above, can be applied to incorporate inorganic MLLW (organic solidification has not been addressed) using local contaminated soils as the aluminosilicate pozzolanic substrate (Siemer 1995). This approach results in very high waste loadings.

A-3.3.2.3.3 R\&D Related to MLLW. Numerous cementitious solidification processes have been investigated where concerns centered upon the release of specific radionuclides. Table A-10 summarizes some of the wastes addressed by these studies.

Table A-10. Representative wastes immobilized in cementitious matrices.

\begin{tabular}{ll}
\hline Waste & Reference \\
\hline${ }^{14} \mathrm{C}$ & Heikkinen (1990) \\
${ }^{3} \mathrm{H}$ & Amano et al. (1986); Anderson and Kerhner (1976); \\
& Lamberger et al. 1980,1981,1983a,b \\
$\mathrm{Tc}$ & Brodda (1986); Tallent et al. (1988); McDaniel and Delzer \\
& $(1989)$ \\
$\mathrm{Cs}$ & Anderson et al. (1980, 1983); Roy et al. (1986); Kumar \\
& (1985) \\
$\mathrm{I}$ & Anderson et al. (1983);Yuanfang and von Guntern (1988); \\
& Roy et al. (1986), Kumar (1985) \\
ion exchange resins & Aalto (1992); Pihlajavaara and Pihlman (1983); Ipatti (1990) \\
chelated nuclides & Dicke et al. (1993) \\
TRU & Heimann (1988) \\
${ }^{60} \mathrm{Co}$ & Plecas et al. (1987) \\
${ }^{90} \mathrm{Sr}$ & Serne et al. (1989) \\
$\mathrm{Nd}, \mathrm{U}, \mathrm{Th}$, Sr & Serne et al. (1996)
\end{tabular}

Many of the studies utilized blends of Portland cement with mineral admixtures derived from industrial wastes such as fly ash and blast furnace slags. The use of slags has been reported to control the release rates of such ions as Tc and $\mathrm{Cr}$ (Tallent et al. 1988; McDaniel et al. 1989; Serne et al 1989; Malek and Roy 1983; Glasser and Marr 1984, 1985; Langton et al. 1983; Wilhite et al. 1988; Glasser et al. 1993). Slags derived from steel-making blast furnaces are glassy and contain sulfur and sulfide ions. 
The sulfur along with an incidental amount of metallic iron is responsible for slag cement's ability to redox buffer the poly-valent ionic species in these waste forms. The Eh of pore fluids of conventional Portland cement is +400 mvolts, but in the presence of slag this value can drop as low as -400 mvolts (Glasser et al. 1993). Furthermore, slag hydrates at a much slower rate than Portland cement resulting in a pore distribution that trends to a smaller size distribution (Roy and Scheetz 1993), which minimizes leaching.

A-3.3.2.3.4 In Situ Placement. ORNL has practiced hydrofracture grout implacement for a number of years. Two distinct periods of placement have occurred. The first operated successfully from the mid-1960s to the early 1970 s and the second, with questionable success, in the mid-1980s. Weeren et al. (1979) reported the disposal of intermediate-level wastes formulated in a pumpable grout mixture containing Portland cement, fly ash drilling clay, pottery clay and a retarder. The shale beneath the pumping site would be drilled, sealed off and then pressurized (with water) to exceed the lithostatic load. This resulted in a splitting of the shale layers. The grout slurry was then pressure injected into the newly fractured zone. The grout would disperse laterally as much as several hundred feet and eventually set to form a thin, pancake-shaped cementitous waste form sandwiched between the shale layers. The next grout injection would be repeated at a shallower depth. Enough time was left between successive injections to allow the grout to equilibrate with the Conasaga Shale formation (DeLaguna et al. 1968). The shale is highly absorbent for Cs, and is responsible for the excellent performance observed in the earlier injections. The second episode of hydrofracture injection was not as successful because radionuclides subsequently leached some distance from the injection point. The primary difference between these two episodes was the time allowed for equilibration and setting of the grout between subsequent injections. In the latter case, insufficient time was allowed for the labile ions to sorb into the shale.

A-3.3.2.4 Testing. The mechanism for the leaching of cementitious waste forms has been established as the diffusion of aqueous species dissolved in the high activity pore waters of the hardened matrix through the tortuous path of the pore structure. The importance of controlling the porosity, the pore size distribution, tortuosity and access to the waste form surface is now fully appreciated. Total porosity and tortuosity are related to the water to cement ratio and the choice of cementitious agents, i.e. blast furnace slag, which determines the pore size distribution.

A-3.3.2.4.1 Hydrofracture Grouts. Leach testing of the hydrofracture grouts are reported by Godbee (1980) and Moore (1981). for cesium, strontium, plutonium and curium. Effective diffusion coefficients of the various species are reported to be $10^{-12}$ to $10^{-14} \mathrm{~cm}^{2} \mathrm{sec}^{-1}$ for Cs; typically $5 \times 10^{-12}$ for $\mathrm{Sr}$, and $10^{-16}$ to $10^{-17}$ for $\mathrm{Cm}$ and $\mathrm{Pu}$. Stinton et al. (1984) examined core samples recovered from hydrofracture grout injections in the early 1960's (20 year old samples) and determined that there was no migration of Cs outside the grout layers after 20 years and that the Cs was associated with the illitic clays in the Conasaga Shale.

A-3.3.2.4.2 FUETAP. FUETAP waste forms formulated with 15 to $25 \%$ SRP defense-type HLW waste have been subjected to systematic characterization. Dole et al. (1983), Moore et al. (1981), and $\mathrm{McDaniel}$ and Delzer (1988) report thermally stable solids (to $400^{\circ} \mathrm{C}$ ) possessing compressive strengths of $>60 \mathrm{MPa}$ and leachabilities of $1 \times 10^{-6}, 1 \times 10^{-4}$ and $1 \times 10^{-8} \mathrm{~g} / \mathrm{cm}^{2} / \mathrm{d}$ for $\mathrm{Cs}, \mathrm{Sr}$ and $\mathrm{Pu}$, respectively, values 
consistent with borosilicate glass. ${ }^{.}$Specimens with $0.6 \mathrm{mg}{ }^{244} \mathrm{Cm} / \mathrm{g}$ were tested for 1 year to evaluate the potential for radiolytic gas generation, and found to produce $\cong 5 \%$ of the amount generated by similarly doped ordinary Portland cement concretes.

A-3.3.2.4.3 Miscellaneous Large-Scale and/or Long-Term Studies. A number of studies are reported in the literature that were conducted on full-scale waste forms, in some cases conducted for several years. Bernard, Nomine, and Codsrnec (1981) from the Commissariat a L'Energie Atomique reported on $200-\mathrm{L}$ cylinders that were leached for 18 months at $20^{\circ} \mathrm{C}$ in flowing water moving at 2.5 $\mathrm{cm} / \mathrm{hr}$. Leachate analyses reported $0.0001 \%$ of the initial inventory of ${ }^{137} \mathrm{Cs}$ and $5 \times 10^{-8} \%$ of the initial inventory of ${ }^{239} \mathrm{Pu}$. Christensen reported on a system to contain ILW and LLW ion exchange resins. ${ }^{d}$ In a 6-year period, $200 \mathrm{ILW}$ molds measuring $1.2 \times 1.2 \times 1.2 \mathrm{~m}$ with a wall thickness of $0.25 \mathrm{~m}$ were used to contain a cementitious waste form made up of Portland cement and mixed bed resins from PWR and BWR reactor maintenance. The program also accumulated $400 \mathrm{LLW}$ molds of the same dimension, but with a wall thickness of $0.1 \mathrm{~m}$. The specific activity of these $6001.73 \mathrm{~m}^{3}$ monoliths ranged from 0.1 to $300 \mathrm{Ci} / \mathrm{m}^{3}$. Cores recovered from these full-scale samples showed a homogeneous distribution of bed resins with a compressive strength ranging from 5,000 to 7,000 psi. The leach rate of cesium ranged from $9 \times 10^{-7}$ to $1.3 \times 10^{-9} \mathrm{~g} / \mathrm{cm}^{2} / \mathrm{d}$, depending upon the particular resin. The Nuclear Waste Commission of Finnish Power Companies (Ipatti 1990) in 1987 initiated long-term testing of spent ion-exchange resins solidified in half-scale concrete containers at the Loviisa Power Plant. After three years exposure to groundwater, no unexpected results were recorded. The canisters are in "good" condition and the "momentary leach rates of Cs and Sr have corresponded well with the results of earlier experiments." "The leaching of cobalt has been particularly minor... ." Three years later Ipatti (1993) reported that a "full-scale experiment" in slowly flowing water had been initiated.

\section{A-3.3.2.4.4 Leach Testing on Alkali-Activated Cement Waste Forms. Siemer et al.} (1996) describes EPA 1310, ANSI 16.1, and MCC-1 testing on representative samples of alkali-activated cement waste forms formulated with INEL calcine and INEL soil with waste loading of $36 \mathrm{wt} \%$. Compressive strengths of the waste forms were reported at $4,600 \mathrm{psi}$, and with the exception of NA and $\mathrm{K}$ in the MCC-1 test, leach test performance was well within the limits of all of the various testing protocol. The AAC cement waste forms were then HIP-vitrified into a glass-ceramic, which was then subjected to evaluation via the PCT protocol. Results from these tests show that the vitrified AAC waste forms easily pass that test as well.

\section{A-3.3.3 Thermoplastic and Thermosetting Polymer Encapsulation Waste Forms}

Polymer waste forms include numerous organic and inorganic binder materials and diverse processing techniques. In general, however, they are produced at low (e.g., $<180^{\circ} \mathrm{C}$ ) or ambient temperature and do not react chemically with the waste being treated. They can be used in either microencapsulation or macroencapsulation applications, as defined below, depending on the physical properties of the waste.

c. A value for total release rate of $10^{-4} \mathrm{~g} / \mathrm{cm}^{2} / \mathrm{d}$ is normally used to model release from borosilicate glass in high-level waste performance assessments.

d. Christensen, H., 1976, Chemical Process Engineering, ASEA-ATOM, Vasteras, Sweden (personal communication). 
Microencapsulation: A thorough and homogeneous mixing of small waste particles with a liquid binder, which then solidifies to form a solid monolithic final waste form. Individual waste particles are coated and surrounded by the solidified binder to provide mechanical integrity and a barrier against leaching of contaminants.

Macroencapsulation: Compactly packaging large pieces of waste not suitable for processing by microencapsulation (e.g., debris, large pieces of solid metal) and surrounding the package with a layer of clean binder. The EPA defines waste with average particle size $>60 \mathrm{~mm}$ as debris waste, suitable for macroencapsulation. The binder forms a "cocoon" around the waste, which provides structural support and helps prevent migration of contaminants.

Polymers can be grouped in two distinct categories, thermoplastic and thermosetting, based on the means required for processing.

Thermoplastic Binders: Materials with a linear molecular structure that repeatedly melt to a flowable state when heated and then harden to a solid when cooled. Polyethylene, sulfur polymer, and bitumen are thermoplastic materials used for waste treatment. Polyethylene and sulfur polymer technologies were developed within DOE, have been demonstrated through pilot-scale, and are currently being commercialized. Bitumen has seen some use both in the U.S. and internationally for solidification of LLW, but due to issues of long-term durability and potential flammability, has not achieved widespread acceptance. Thermoplastics, when used for microencapsulation, are heated, homogeneously mixed with dry waste particles, and allowed to cool into a monolithic solid waste form. Each individual waste particle is surrounded by the thermoplastic binder to minimize leachability. For macroencapsulation, the molten thermoplastic is poured into a waste container in which large pieces of waste material have been suspended or supported. Upon cooling, the thermoplastic forms a solid polymer layer surrounding the waste.

Thermosetting Binders: Materials that require the combination of several ingredients (e.g., monomer, catalyst, promoter) to polymerize and harden to a solid and which cannot be reversed back to a flowable state without destroying the original characteristics. Vinylester styrene, polyester styrene, and epoxies are examples of thermosetting resins that have been used for waste treatment. Thermosetting resins can be used for microencapsulation and macroencapsulation of waste, as well as for in-situ stabilization/solidification.

The properties of each polymer system discussed in this report (i.e., polyethylene, sulfur polymer, and thermosetting resins) are reviewed briefly below.

A-3.3.3.1 Polyethylene. Polyethylene is an inert crystalline-amorphous thermoplastic material with a relatively low melting temperature. It is produced through polymerization of ethylene gas and the structure of the plastic can be varied widely to create products with different properties. For example, high-density polyethylene (HDPE) is produced by creating long polymer chains with relatively little branching, allowing the polymer layers to be closely packed. Typical HDPE densities range between 0.941 and $0.959 \mathrm{~g} / \mathrm{cm}^{3}\left(58.7\right.$ and $\left.59.9 \mathrm{lbs} / \mathrm{ft}^{3}\right)$. Low-density polyethylene (LDPE) is produced by inducing a higher degree of chain branching, which keeps the layers further apart. The branches in LDPE occur at a frequency of 10-20 per 1,000 carbon atoms, creating a relatively open structure. Typical LDPE densities range between 0.910 and $0.925 \mathrm{~g} / \mathrm{cm}^{3}\left(56.8\right.$ and $\left.57.7 \mathrm{lbs} / \mathrm{ft}^{3}\right)$. LDPE has a lower 
melt temperature $\left(120^{\circ} \mathrm{C}\left[248^{\circ} \mathrm{F}\right]\right)$ and melt viscosity than HDPE $\left(180^{\circ} \mathrm{C}\left[356^{\circ} \mathrm{F}\right]\right)$, and thus is easier to process for waste encapsulation applications. Polymer melt viscosity is inversely proportional to molecular weight and is characterized in terms of the melt index, which describes the flow of molten polymer under standard conditions specified by the American Society of Testing and Materials (ASTM 1991). Low-density polyethylene is commercially available with melt indices ranging from $1-55 \mathrm{~g} / 10 \mathrm{~min}$.

A-3.3.3.2 Sulfur Polymer. Sulfur polymer cement (SPC) was developed by the U.S. Bureau of Mines in an attempt to create new, commercially viable construction applications for by-product sulfur produced during the refining of petroleum and in the cleanup of $\mathrm{SO}_{2}$ stack gases. It was initially applied for the treatment of radioactive, hazardous, and mixed wastes by Brookhaven National Lab (Kalb and Colombo 1985) and has subsequently been investigated by the Commission of the European Communities (Van Dalen and Rijpkema 1989), Idaho National Engineering Laboratory (Darnell 1991), and Oak Ridge National Laboratory (Mattus and Mattus 1994). It is produced by combining elemental sulfur with readily available and relatively inexpensive chemical modifiers which significantly improve product durability. Elemental sulfur is reacted with $5 \mathrm{wt} \%$ dicyclopentadiene, which suppresses the solid phase transition in the unmodified material responsible for lowering density and creating an unstable solid. Sulfur polymer cement is manufactured commercially under license from the USBM, and is marketed under the trade name Chement 2000 (Martin Resources, Odessa, TX). Despite its name, SPC is a thermoplastic material, not a hydraulic cement. It has a relatively low melting point of $120^{\circ} \mathrm{C}$ $\left(248^{\circ} \mathrm{F}\right)$ and melt viscosity of about 25 centipoise $(0.0168 \mathrm{lb} / \mathrm{ft} \cdot \mathrm{s})$, and thus can be processed easily by a simple heated stirred mixer.

A-3.3.3.3 Thermosetting Polymers. Thermosetting polymers are formed by the polymerization of an unsaturated monomer (e.g., methacrylates), typically by a chain reaction. The reaction is initiated by a chemical catalyst such as benzoyl peroxide, which is decomposed by thermal energy or the action of a chemical promoter such as dimethyl toluidine. The decomposition breaks $\mathrm{O}-\mathrm{O}$ bonds, forming free radicals that have unpaired electrons which are highly reactive. The free radicals, in turn, react to break the double bonds of the monomer and add to it. This process is exothermic and continues rapidly, as more and more monomers add to the chain. The reaction finally terminates when the monomer is consumed or chains meet end to end. It can be controlled by temperature (increased temperature accelerates the chain reaction), promoter-catalyst combinations and concentrations, and the presence of admixtures (or waste materials) that can retard or accelerate the set. The time at which the resin viscosity increases rapidly and can no longer be poured or worked is known as the gel time, and can be varied by the resin or catalyst-promoter manufacturer.

A-3.3.3.4 Process /ssues. Broad application to diverse waste streams is one of the primary advantages of polymer waste form processes. Polymer waste form technologies can be used for production of cost-effective final waste forms with improved durability and leaching performance. In general, they can be applied to a wide range of process wastes, including aqueous liquid concentrates, sludges, ash residues, ion exchange resins, contaminated parts and equipment, and secondary wastes from off-gas treatment. In addition, polymer technologies can be used for environmental remediation applications including direct treatment of soils, sludges, and debris, indirect treatment of soil washing and other volume reduction process residuals, and remediation of failed conventional concrete waste forms. No technology has universal applicability, however, and thus no polymer technology can be used to treat all types of waste. 
The selection and application of any final waste form technology depends on a number of factors, such as waste characteristics, waste volumes, treatment and disposal costs, and regulatory reçuirements. For polymer encapsulation technologies, specific issues that impact selection of the type of polymer (organic vs. inorganic, thermoplastic vs. thermosetting) and the method of treatment (microencapsulation vs. macroencapsulation, in-situ vs. ex-situ) include chemical and physical properties of the waste, ultimate disposition of the treated waste, disposal site waste acceptance criteria, final waste form performance criteria, capital and operating costs, availability of materials, ease of processing, and reliability. These issues are discussed below.

A-3.3.3.4.1 Chemical Properties of the Waste-Thermosetting polymers require a chemical polymerization reaction to form a solid product, and thus are susceptible to interactions with constituents found in the waste that can adversely impact the solidification process. For example, wastes that contain reducing agents or sorbents can interfere with the effectiveness of the catalyst to initiate and complete polymerization. Thermoplastic polymers do not rely on chemical reactions to form a solid final waste form product and solidification is assured on cooling. However, thermoplastic polymers cool to a solid when exposed to a large a thermal mass (e.g., soil) and thus are less suitable for in-situ applications.

A-3.3.3.4.2 Physical Properties of the Waste-Physical properties of the waste that can impact polymer processes include particle size and distribution, density, and moisture content. In general, wastes that consist of small particles are treated more effectively by microencapsulation. The smaller the waste particles, the greater the ratio of polymer/waste surface area, resulting in improved leachability. However, microencapsulation processing of extremely fine or large particles may be limited for some thermoplastic technologies. Large particles that are considered as debris ( $>60 \mathrm{~mm}[2.4$ inches]) are more effectively treated by macroencapsulation.

Thermoplastic processes operate at temperatures in the range of $120-180^{\circ} \mathrm{C}\left(248-356^{\circ} \mathrm{F}\right)$, so that moisture contained in the waste is volatilized. In most cases, it is advantageous to pretreat the waste to remove residual moisture. Small quantities of moisture (e.g., $<2 \mathrm{wt} \%$ ) can be removed during extrusion processing. An alternative processing method that can rapidly drive off moisture before entrainment in the polymer is currently under development by BNL under support from the DOE Mixed Waste Focus Area. Although most hazardous metals and radioactive contaminants are not volatile at expected thermoplastic process temperatures, some highly volatile species (e.g., mercury) may require capture in the off-gas or auxiliary treatment. For wastes containing significant concentrations of VOCs ( $>5 \mathrm{wt} \%)$, removal and destruction of the organics is recommended before treatment by polymer encapsulation. Some thermosetting resins can tolerate significant levels of moisture by forming a high-shear emulsion of the waste within the polymer before solidification, which traps small droplets of the moisture within the final waste form.

\section{A-3.3.3.4.3 Disposal Disposition, Waste Acceptance Criteria, and Final Waste Form}

Performance Required-Final waste form performance requirements are dictated by the properties of the waste itself (e.g., radioactive, hazardous, mixed), levels of contaminants, and where the treated waste will ultimately be disposed (e.g., disposal site design, climate). Ultimately, DOE site-specific performance criteria should be the driver for the type of waste form and the performance standards required. Waste form performance issues that can influence selection of polymer encapsulation technologies include mechanical integrity, durability, leachability, biostability, and radiation stability. 
A-3.3.3.4.4 Cost-The cost of polymer materials varies widely, from a low of about $\$ 0.26 / \mathrm{kg}$ $(\$ 0.12 / \mathrm{lb})$ for sulfur polymer to a high of more than $\$ 14.33 / \mathrm{kg}(\$ 6.50 / \mathrm{lb})$ for polysiloxanes and some epoxies. Cost comparisons are further complicated by variations in waste loading efficiencies which impact the number of drums processed for disposal, shipping costs, disposal costs, and processing costs. Thus, it is particularly important to conduct life cycle cost estimates for specific polymer encapsulation technologies under consideration.

A-3.3.3.4.5 Availability-Most polymers that have been considered or used for waste encapsulation are readily available commercially. Some polymers, however, are not widely used for other applications and/or may be produced by a limited number of suppliers. At any given time these materials may be in short supply, especially without advance notification to the manufacturer. The demand for some polymers used for waste encapsulation could exceed the production of materials manufactured for conventional applications, creating viable new markets. However, polymer manufacturers should easily be able to meet any increased market demands.

A-3.3.3.4.6 Simplicity of Process-Polymer processes vary in complexity from relatively simple thermoplastic materials requiring heating/mechanical batch mixing (e.g., sulfur polymer) to more complicated thermosetting polymers that require precise addition of catalyst and promoters to initiate chemical polymerization. Polymer processing is done at ambient temperatures (thermosetting polymers) or at relatively low elevated temperatures $\left(150^{\circ} \mathrm{C}\left[302^{\circ} \mathrm{F}\right]\right.$ for $\left.\mathrm{LDPE}\right)$, reducing or eliminating the need for complex off-gas collection and secondary waste treatment, an advantage compared with higher temperature vitrification processes.

A-3.3.3.4.7 Reliability-Although polymers are relatively new engineering materials, polymer processes in general, and thermoplastic processes in particular have proven reliable in other applications in over 50 years of development. Thermoplastics are routinely processed for such applications as packaging, piping, mechanical parts, etc., providing a large base of experience and high level of reliability.

A-3.3.3.4.8 Rework Capability-Thermoplastic polymers possess a unique advantage in that they can be readily reprocessed, if necessary, by simply remelting and reforming the waste form. In a similar fashion, processing can be restarted following unplanned shutdowns, by simply reheating materials to a molten state. This unique property of thermoplastic resins also allows the use of recycled plastics from either industrial or post-consumer sources. In this way, waste materials can be used to treat more hazardous wastes.

Thermoplastic polymer processing for microencapsulation is achieved by heating the polymer binder to the melting temperature, adding the waste material, and mixing to a homogeneous condition. Depending on the type of polymer, this can be achieved by simple heated batch mixers (e.g., double planetary mixers), extruders (single screw or twin screw), and thermokinetic mixers. Thermosetting polymers are processed by adding a small quantity of catalyst and promoter to the thermosetting monomer, adding the waste material, mixing to form a homogeneous blend and allowing time for the polymerization reaction to occur. In the case of in-situ applications, low-viscosity thermosetting monomers are used. These materials are applied by either flooding the waste (e.g., soil) by a technique known as permeation grouting or by injecting the monomer into the waste under pressure by a technique known as jet grouting. 
Depending on the type of polymer technology selected, processing may be limited by issues of particle size, density, and moisture content. These limitations can usually be ameliorated, however, by implementing appropriate pre-treatment technologies such as drying, emulsifying, size reduction or agglomeration. In other cases, the polymer processing equipment itself can be modified to improve processibility and final waste form performance. For example, BNL is currently developing a thermokinetic processing system for pretreatment of wastes containing moisture or volatile organics and off-spec particle size materials.

A-3.3.3.5 Product Performance /ssues. Long-term durability of LDPE for use in encapsulating waste has been demonstrated (Kalb et al. 1993). Polyethylene is resistant to a wide range of chemicals and solvents, thermal cycling, saturated conditions, and microbial attack. Durability is confirmed by the fact that the U.S. EPA has been unsuccessful in finding ways to make polyethylene degrade by means of biodegradation in current municipal solid waste landfills. When exposed to radiation doses up to $10^{8}$ $\mathrm{rad}$, increased cross-linking of polymer chains results in greater mechanical strength and lower leachability. Polyethylene waste forms have been shown to have radionuclide leachabilities of at least two orders of magnitude lower than conventional concrete waste forms and have passed EPA's Toxicity Characterization Leaching Procedure (TCLP) tests for toxic metals, reducing metals concentrations by more than 1,000 times.

Compared with hydraulic Portland cements, sulfur polymer cement has a number of performance advantages. Sulfur polymer concrete compressive and tensile strengths have been attained that are twice those of comparable Portland concretes. Full strength is reached in a matter of hours rather than several weeks. Concretes prepared using sulfur polymer cements are extremely resistant to most acids and salts. Sulfates, for example, which are known to attack hydraulic cements, have little or no effect on the integrity of sulfur polymer cement. Sulfur polymer waste forms have been subjected to numerous performance tests to determine durability and leaching properties under anticipated storage and disposal conditions. Testing to demonstrate compliance with the NRC guidelines for 10 CFR 61 indicate that for each property tested, results far exceed minimum test criteria recommended by the NRC. Radionuclide leachability for SPC is similar to polyethylene. Leachability testing of characteristic toxic constituents under EPA TCLP have been conducted. For example, incinerator ash containing $7.5 \mathrm{wt} \%$ lead and 0.2 $w t \%$ cadmium encapsulated in sulfur polymer with additives resulted in leachable levels of $1.5 \mathrm{ppm} \mathrm{Pb}$ and $0.2 \mathrm{ppm} \mathrm{Cd}$, below existing allowable concentrations of 5.0 and $1.0 \mathrm{ppm}$, respectively.

Thermosetting resins have undergone extensive durability and performance testing for use in both ex-situ and in-situ waste treatment applications. Since they are typically low in viscosity (3-300 centipoise [ $\left.2 \times 10^{-3}-2.02 \times 10^{-1} \mathrm{lbs} / \mathrm{ft} \bullet \mathrm{s}\right]$ ), they are readily adaptable to in-situ injection in soil. (Heiser et al. 1992). When combined with waste aggregates to form a polymer concrete, they have excellent mechanical strength (up to $48.3 \mathrm{MPa}[7,000 \mathrm{psi}]$ or greater, depending on the type of soil aggregate). In-situ polymer concretes formed from contaminated soils have been shown to be highly resistant to aggressive chemicals (acidic and alkaline environments), thermal and wet-dry cycling, microbial degradation, and radiation doses to $10^{8} \mathrm{rad}$. Low hydraulic conductivity $\left(<10^{-12} \mathrm{~cm} / \mathrm{sec}\left[<3.9 \times 10^{-13}\right.\right.$ in/sec] ) and leachability have been demonstrated. A disadvantage of thermosetting polymers is that, unlike thermoplastic polymers, once polymerized they cannot be reworked. 


\section{A-3.3.4 Specialty Waste Forms (Mercury Amalgams, etc.)}

Specialty waste forms may be needed to treat specific, problematic waste streams. These wastes are either part of the existing inventory, or will be generated as secondary waste streams by some proposed treatment processes. While these special waste streams present special challenges because of unusual chemical and/or physical properties (explosive, pyrophoric, volatile, etc.), the current inventory shows that they only represent a little over $1 \%$ of the Department's total MLLW inventory (see Table 3-1). Nevertheless, because of the unique properties of these wastes, special attention must be given to waste form and treatment process selection.

Explosive materials are not considered highly reactive under normal storage and handling conditions. However, these materials may become unstable if they begin to degrade, and special handling will be required. Chemical compatibility with the treatment process must be carefully evaluated to avoid uncontrolled reactions. As a result, waste form selection may be determined by processing requirements.

Pyrophoric materials are by nature highly reactive. These materials will require special handling to avoid uncontrolled reactions. In addition, chemical compatibility with the treatment process and/or the waste form must be carefully evaluated, and may dominate the waste form selection process.

Mercury is volatile at moderate temperatures, is not very compatible with many waste forms and/or processes, and is separated from waste streams in a variety of ways. It generally forms a small volume secondary stream. Amalgamation is often proposed for mercury immobilization, although sulfur polymer cement has been proposed in the past, and may offer some advantages.

A more detailed discussion of waste form characteristics, advantages, and disadvantages can be found in Volume I of Mayberry et al. (1993). However, with special wastes, the waste form itself is often less of an issue than processing conditions. Each special waste stream must be assessed on an individual basis to select compatible treatment processes. It may prove more economical for sites with small volumes of special wastes to transport that waste to another site with existing treatment capability rather than treat the waste onsite. Even if a special waste form is selected, data on release mechanisms and waste form performance with these wastes are very limited. 


\section{A-4. WASTE FORM COMPARISONS}

When comparing waste forms to assess suitability for a particular mission, a variety of factors, both technical and non-technical, must be considered. Technical factors seldom dominate the analysis, but are often easier to quantify and analyze. Before relative importance can be assigned to the various factors influencing the analysis, the waste dispositioning mission must be clearly defined.

\section{A-4.1 Evaluation Criteria}

\section{A-4.1.1 Waste Stream}

Waste streams must be compatible with waste form chemistry and the processing conditions necessary to produce the waste form. A high-temperature waste form, for example, would be a poor candidate for immobilizing a waste stream with a high concentration of volatiles. The waste stream can be used as an initial screening to eliminate unacceptable waste forms from further consideration.

\section{A-4.1.2 Process}

The waste form production process must be stable enough to ensure an acceptable product despite composition fluctuations in the input stream. The process must be reliable, and provide sufficient throughput to process the projected waste inventory in a "reasonable" time (as defined by the waste dispositioning mission). The process should also minimize the volume of secondary wastes requiring further processing.

\section{A-4.1.3 Disposal Site}

Disposal sites vary considerably in terms of local precipitation (providing water for potential migration of radionuclides and contaminants), ground water chemistry, and geology. Disposal system performance is defined in terms of releases from the filled and closed disposal site. Performance assessments can be used to establish basic criteria, with additional criteria being prescribed by regulations.

\section{A-4.1.4 Waste Form}

The most important performance criteria for waste forms are leach rate and compressive strength (see discussion in Section A-4.2 and Table A-11). Leach rate measures the rate of release of radionuclides and toxic elements, and compressive strength influences stability of the disposal site and, thereby, the amount of water that contacts the waste. These performance criteria must be established in conjunction with either specific disposal site acceptance criteria, or generic acceptance criteria generated from hypothetical disposal site characteristics that bound the expected characteristics of candidate sites.

In addition to performance criteria, there are other criteria that relate to waste form evaluation. For example, volume reduction ultimately influences life-cycle costs, primarily by affecting disposal costs. Final waste form volume can be calculated from the following equation for waste form volume: 


$$
V_{W F}=V_{W}+\frac{m_{W}\left(\frac{1-L_{W}}{L_{W}}\right)}{\rho_{A}}
$$

where

$$
\begin{aligned}
& \mathrm{V}_{\mathrm{WF}}=\text { waste form volume } \\
& \mathrm{m}_{\mathrm{W}}=\text { waste mass (weight) } \\
& \mathrm{L}_{\mathrm{W}}=\text { weight fraction of waste in the final waste form } \\
& \rho_{\mathrm{A}}=\text { density of the stabilizing additive. }
\end{aligned}
$$

In addition to disposal costs, final waste form volume influences transportation costs, and may significantly influence the size (and therefore cost) of interim storage facilities.

\section{A-4.2 Comparisons}

Before actual comparisons are made, screening tests should be applied to eliminate those waste forms that may be unsuitable for purely technical reasons. First, the waste stream(s) to be treated must be characterized in sufficient detail to assess compatibility with the basic physical and chemical properties of the waste form, and the processing conditions required to produce the waste form. Secondary waste streams requiring further treatment should be carefully characterized when evaluating the waste form production process. Some waste forms may require a reduced waste loading to pass these screening tests, but they should still be retained for subsequent consideration.

Waste acceptance criteria (derived from performance assessments/evaluations) should be obtained either from the actual proposed disposal site, or from a generic site where the conditions bound the anticipated conditions at the proposed site. Waste form properties are then compared to the waste acceptance criteria to evaluate compliance. Waste forms that cannot comply with waste acceptance criteria should be eliminated from further consideration.

Candidate waste forms should then be evaluated to estimate final waste form volume and costs. Figure 4-1 shows final waste form volumes calculated for several candidate waste forms as a function of waste loading (weight fraction). 


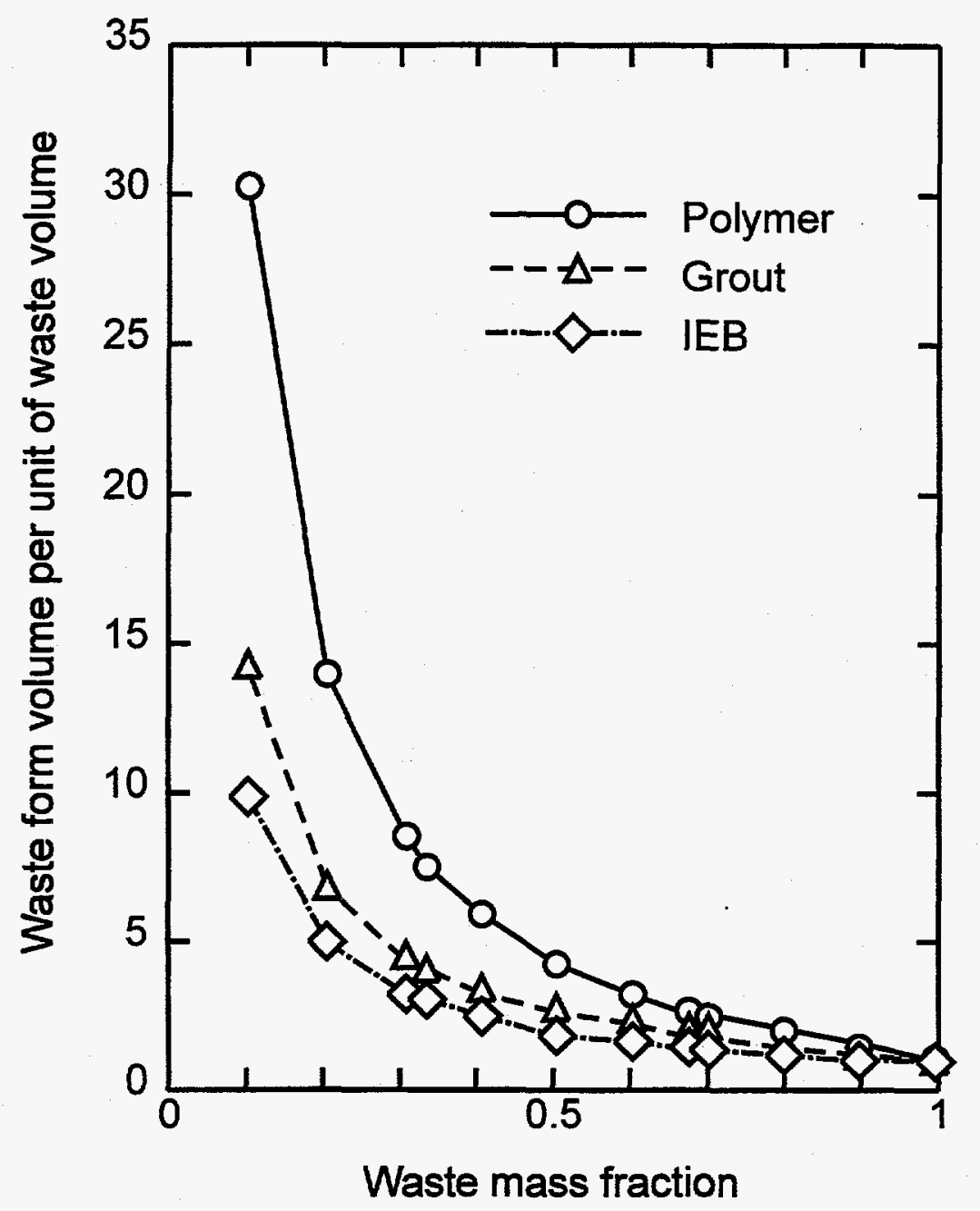

M96 0373

Figure A-5. Final waste form volume per unit volume of treated waste as a function of waste loading (weight or mass fraction) for several candidate waste forms. The input waste stream was considered a solid stream after removal of volatiles and/or combustion, as applicable.

From Figure A-5 it can be seen that at high waste loadings, all waste forms are about equivalent. However, for practical reasons related to waste chemistry and/or processing conditions, not all waste forms are capable of the same maximum waste loadings. For many waste streams, hydraulic cements are limited to waste loadings around $33 \mathrm{wt} \%$, encapsulants like polyethylene are limited to about $50 \mathrm{wt} \%$, while high-temperature waste forms such as iron-enriched basalt can achieve loadings around $67 \mathrm{wt} \%$. These practical considerations provide the basis for discriminating between waste forms according to volume reduction.

Cost analysis has been treated extensively elsewhere (Shropshire et al. 1995; Harvego and Schafer 1996), and has shown that overall life-cycle costs are most affected by disposal costs. This conclusion emphasizes the volume reduction capabilities of candidate waste forms and associated processes. 
However, uncertainties in the chemical and physical characteristics of the waste to be treated and the abilities of hypothetical processes to deal with these uncertainties reduces confidence in the pretreatment cost estimates used in these analyses. Caution is advised when applying these data to waste form comparisons until confidence in the estimation bases can be improved. Ultimately, these data may be most useful not for comparing waste forms, but for cost-benefit analyses of waste treatment and disposal requirements imposed by political and stakeholder concerns.

An estimate of the risks associated with candidate treatment, storage, and disposal systems should be made. The risks should be compared to other local commonly accepted risks, and contrasted to the benefits to be accrued by treating and disposing of the waste.

The remaining waste forms can then be ranked based on safety and cost effectiveness, and the results presented to stakeholders. Certainly, the stakeholders must be involved in this entire process, but this point where waste form and treatment process is formally selected deserves special attention. Stakeholder buy-in is required to complete the selection process and proceed with implementation.

The waste forms considered in this study were divided into four groups for convenience:

1. High-temperature (glass, ceramic, glass-ceramic)

2. Hydraulic cements

3. Encapsulants (polymers, bitumen, sulfur-polymer)

4. Specialty waste forms.

Typical ranges of performance properties for these waste form groups are listed in Table A-11 for comparison. Property values are influenced by a variety of factors, including waste stream chemistry and waste loading. Compressive strength is the most quantitatively comparable characteristic in Table A-11. The ranges listed for organic encapsulants, sulfur polymer cement, and hydraulic cement show the effects of waste loading and interactions with some waste streams. The compressive strength of high-temperature waste forms (glass and ceramic) is not appreciably affected by waste loading. It is also about an order of magnitude higher than other waste forms, and is therefore not routinely measured.

Quantitative data is available on leachability, but, as discussed above, the available data for high-temperature waste forms is not directly comparable to low-temperature waste forms (encapsulants, hydraulic cements, etc.). The range in leachability indices for the low-temperature waste forms is generally a result of varying waste loadings, and/or data reported for different elements of interest.

The other characteristics listed in Table A-11 are less quantitative than leachability and compressive strength, but most waste forms can be tailored to satisfy established criteria with most waste streams. Biological stability and thermal cycling have not been observed to be problems for any of the waste forms listed in Table A-11. Flammability is only an issue for organic encapsulants and sulfur polymer cement. Free liquids have occasionally been observed when some wastes are stabilized with thermosets or hydraulic cements. Gas generation has only been observed with organic encapsulants in response to radiation damage. Only cement-type waste forms have shown sensitivity to the immersion 
stability test, and then only with certain wastes that tend to swell in contact with water. Organic encapsulants sometimes loose compressive strength in response to radiation exposure, but can also increase compressive strength.

Table A-11. Summary of waste form properties.

\begin{tabular}{|c|c|c|c|c|c|}
\hline Characteristic & Glass & Ceramic & $\begin{array}{c}\text { Encapsulants } \\
\text { (organic) }\end{array}$ & $\begin{array}{c}\text { Sulfur Polymer } \\
\text { Cement }^{\mathrm{a}}\end{array}$ & Hydraulic Cement \\
\hline Leachability & $\mathrm{s} 1 \mathrm{gm} / \mathrm{m}^{2} / \mathrm{da}$ & $10^{-3}$ to $10^{-5} \mathrm{gm} / \mathrm{m}^{2} / \mathrm{da}$ & $\begin{array}{l}\text { Leach index } \\
\text { from } 6 \text { to } 14\end{array}$ & & $\begin{array}{l}\text { Leach index from } \\
6 \text { to } 10 \text { for Cs } \\
\text { (worst case) }\end{array}$ \\
\hline $\begin{array}{l}\text { Compressive } \\
\text { strength }\end{array}$ & $\begin{array}{l}\text { About } 500 \\
\mathrm{MPa}\end{array}$ & $\geq$ about $500 \mathrm{MPa}$ & 0.3 to $30 \mathrm{MPa}$ & 20 to $80 \mathrm{MPa}$ & 3 to $14 \mathrm{MPa}$ \\
\hline $\begin{array}{l}\text { Radiation } \\
\text { stability }\end{array}$ & $\begin{array}{l}\text { Not } \\
\text { significantly } \\
\text { affected }\end{array}$ & $\begin{array}{l}\text { Not significantly } \\
\text { affected }\end{array}$ & $\begin{array}{l}\text { Some loss of } \\
\text { compressive } \\
\text { strength and } \\
\text { gas generation } \\
\text { may occur }\end{array}$ & $\begin{array}{l}\text { Not } \\
\text { significantly } \\
\text { affected }\end{array}$ & $\begin{array}{l}\text { Not significantly } \\
\text { affected. }\end{array}$ \\
\hline $\begin{array}{l}\text { Thermal } \\
\text { cycling } \\
\text { durability }\end{array}$ & $\begin{array}{l}\text { Not } \\
\text { significantly } \\
\text { affected }\end{array}$ & $\begin{array}{l}\text { Not significantly } \\
\text { affected }\end{array}$ & $\begin{array}{l}\text { Not } \\
\text { significantly } \\
\text { affected }\end{array}$ & $\begin{array}{l}\text { Not } \\
\text { significantly } \\
\text { affected }\end{array}$ & $\begin{array}{l}\text { Not significantly } \\
\text { affected. }\end{array}$ \\
\hline $\begin{array}{l}\text { Immersion } \\
\text { stability }\end{array}$ & $\begin{array}{l}\text { Not } \\
\text { significantly } \\
\text { affected }\end{array}$ & $\begin{array}{l}\text { Not significantly } \\
\text { affected }\end{array}$ & $\begin{array}{l}\text { Not } \\
\text { significantly } \\
\text { affected }\end{array}$ & $\begin{array}{l}\text { Not } \\
\text { significantly } \\
\text { affected for } \\
\text { most wastes }\end{array}$ & $\begin{array}{l}\text { Can reduce } \\
\text { compressive } \\
\text { strength. Some } \\
\text { wastes cause } \\
\text { break-up. }\end{array}$ \\
\hline $\begin{array}{l}\text { Gas } \\
\text { generation }\end{array}$ & None & None & $\begin{array}{l}\text { Possible. See } \\
\text { Radiation } \\
\text { Stability }\end{array}$ & None & \\
\hline Free liquids & None & None & $\begin{array}{l}\text { Possible when } \\
\text { thermosets are } \\
\text { used to } \\
\text { encapsulate } \\
\text { some wastes }\end{array}$ & None & $\begin{array}{l}\text { Possible with } \\
\text { some wastes }\end{array}$ \\
\hline Flammability & Not possible & Not possible & $\begin{array}{l}\text { Combustion is } \\
\text { possible, but } \\
\text { not always } \\
\text { self-sustaining }\end{array}$ & $\begin{array}{l}\text { Combustion } \\
\text { possible }\end{array}$ & Not possible \\
\hline $\begin{array}{l}\text { Biological } \\
\text { stability }\end{array}$ & $\begin{array}{l}\text { Not } \\
\text { significantly } \\
\text { affected }\end{array}$ & $\begin{array}{l}\text { Not significantly } \\
\text { affected }\end{array}$ & $\begin{array}{l}\text { Not } \\
\text { significantly } \\
\text { affected }\end{array}$ & $\begin{array}{l}\text { Not } \\
\text { significantly } \\
\text { affected }\end{array}$ & $\begin{array}{l}\text { Not significantly } \\
\text { affected }\end{array}$ \\
\hline
\end{tabular}


Regulatory requirements for the waste form characteristics listed in Table A-11 are described in Table A-2. The regulatory requirements in Table A-2 constitute de facto performance specifications in that they define minimum performance requirements that all waste forms must satisfy. Site-specific waste acceptance criteria, when available, may add to the regulatory requirements, or establish more restrictive performance requirements. Performance assessment methodology is used to help establish site-specific waste acceptance criteria. A variation of performance assessment methodology has recently been used to estimate upper limits of radionuclide and hazardous for cementitious waste forms at various DOE sites across the country (Waters et al 1996). "This methodology, called "performance evaluation," started with specified exposure limits for future populations and calculated backwards (with respect to conventional performance assessment methodology) to derive maximum allowable radionuclide and hazardous concentrations for select elements in candidate waste forms. The calculation assumed a conservative release model for the waste form (i.e., maximum anticipated release rates were assumed). The emphasis here is on release of radionuclides and hazardous elements, which is the waste form characteristic with the most direct impact on disposal site performance. Most other performance requirements, as discussed above, are referenced back to their effect on release performance. The results indicated that, while some waste forms exhibit superior performance characteristics (see Table A-11), even an "inferior" cement waste form could provide acceptable performance with respect to leachability at most sites. While the leach data in Table A-11 are not directly comparable, a qualitative comparison of the data in Table A-11 with the model used in the performance evaluation indicates that the performance of all the waste forms listed in Table A-11 exceeds that of the waste form assumed for the performance evaluation. So, while there may be exceptions for specific combinations of waste composition, process, and waste package, it is anticipated that all of the waste forms listed in Table A-11 can deliver acceptable performance when used to treat most of the Department's MLLW inventory for disposal at most credible disposal sites. In other words, all of the waste forms discussed in this report are "good enough" with respect to release characteristics, provided compatible conditions are maintained between the waste composition, the process, and the resulting waste package as discussed in Section 3 (see also Figure A-2 and accompanying general discussion).

The inadvertent intruder scenarios analyzed as part of the performance assessment/evaluation process can lead to even more restrictive limits on waste form loading than are derived from release and transport models (Waters et al 1996). ${ }^{e}$ The implications of these results for waste package performance must be interpreted with caution, however, because of the subjective nature of the inadvertent intruder scenarios. Also, other factors, such as disposal facility design features, can significantly influence the results of the analysis. For example, the homesteader scenario that involves exhuming some of the waste to excavate a basement for a dwelling becomes irrelevant if the waste is buried deep enough to avoid the excavation. The use of data from the inadvertent intruder scenario analysis to help establish waste package performance criteria should be carefully evaluated. It may be more appropriate to use inadvertent intruder scenarios to help define disposal facility design criteria and post-closure requirements.

e. P. I. Pohl, W. C. Cheng, T. Wheeler, R. D. Waters, Waste Form Performance Assessment Task, draft letter report TTP Al2-6-TI-01, SAND96-XXXX, Sandia National Laboratory, 1996. 


\section{A-5. REFERENCES}

Ackerman, J. P., T. R. Johnson, and J. J. Laidler, 1994, "Waste Removal in Pyrochemical Fuel Processing for the Integral Fast Reactor," in Actinide Processing: Methods and Materials, eds. B. Mishra and W. A. Averill, The Minerals, Metals \& Materials Society, Warrendale, PA, p. 261.

Aloy, A. S., O. A. Iskhakova, A. V. Trofimenko, R. A. Abakumova, A. A. Belyustin, G. V. Konstantinova, 1996, "Water Resistance of Aluminophosphate Glasses with Increased Content of Cesium Oxide," St. Petersburg State University, St. Petersburg, Russia.

Amano, H., Y. Sakuma, T. Okamoto, 1986, International Meeting on Low, Intermediate, and HighLevel Waste Management-Decontamination and Decommissioning, Niagara Falls, NY, pp. 98-111.

Anderson, H. F., C. J. Kerhner, 1976, MLM-2451, Mound Laboratory, p. 26.

Anderson, H. F., B. Torstenfelt, B. Allard, 1980, Materials Research Society.,Vol. 3, pp. 235-242.

Anderson, H. F., B. Torstenfelt, B. Allard, 1983, Svensk Kaernbraenslefoersoerjning AB, SKBF-KBS-TR-83-13, Stockholm, p. 24.

ANSI/ANS, 1986, "American National Standard Measurement of the Leachability of Solidified Low-Level Radioactive Waste by a Short-Term Test Procedure," ANSI/ANS 16.1.

Aslot, H., A. Ipatti, 1992, Materials Research Society, Vol. 294, pp. 375-380.

ASTM, 1991, "Standard Practice for Prediction of Long-Term Behavior of Waste Package Materials Including Waste Forms Used in the Geologic Disposal of Nuclear Waste," ASTM C 1174-91.

ASTM, 1994, "Standard Test Method for Determining the Chemical Durability of Nuclear Waste Glasses: The Product Consistency Test," ASTM C 1285.

Atkinson, A., D. J. Goult, and J. A. Hearne, 1985, Materials Research Society, Vol ??, pp. 239-246.

Atkinson, A., P. A. Claisse, A. W. Harris, 1988, AERE-G-4977, UKAEA Harwell Lab.

Atkinson, A., P. A. Claisse, A. W. Harris, 1989a, Materials Research Society, Vol 176, pp. 741-749.

Atkinson, A., P. A. Claisse, A. K. Nickerson, 1989b, AERE-G-5241, UKAEA Harwell.

Barbston, Wm. N. and Phillip G. Malone, 1993, U.S. Patent 5,252,266.

Barkatt, Al., P. E. Pehrsson, D. Szoke, and P. B. Macedo, 1981, "Static and Dynamic Tests for the Chemical Durability of Nuclear Waste Glass," Nuclear Chemical Waste Management 2, p. 151.

Barnes, M. W., B. E. Scheetz, L. D. Wakeley, S. D. Atkinson, and D. M. Roy, 1982, Materials Research Society, Vol 6, pp. 147-154. 
Bates, J. K., and T. J. Gerding, 1985, "NNWSI Phase II Materials Interaction Test Procedure and Preliminary Results," ANL-84-81.

Bates, J. K., C. R. Bradley, E. C. Buck, J. C. Cunnane, W. L. Ebert, X. Feng, J. J. Mazer, D. J. Wronkiewicz, J. Sproull, W. L. Bourcier, B. P. McGrail, and M. K. Altenhofen, 1994, High-level Waste Borosilicate Glass: A Compendium of Corrosion Characteristics, Vol. 1, Office of Waste Management, United States Department of Energy, DOE-EM-0177.

Battles, J. E., J. J. Laidler, C. C. McPheeters, and W. E. Miller, 1994, "Pyrometallurgical Process for Recovery of Actinide Elements," in Actinide Processing: Methods and Materials, eds. B. Mishra and W. A. Averill (The Minerals, Metals \& Materials Society, Warrendale, PA) p. 135.

Bernard, A., J. C. Nomine, and G. Codsrnec, 1981, Oak Ridge National Laboratory, CONF-8005107, p. 25.

Brodda, B. G., 1986, Symposium on Environmental Radiochemical Analysis, Harwell p. 69.

Chick, L. A., et al., 1986, "Evaluation of Lead-Iron-Phosphate Glass as a High-Level Waste Form," Third International Symposium on Ceramics in Nuclear Waste Management, Chicago, IL.

Conner, Jesse R., 1990, Chemical Fixation and Solidification of Hazardous Wastes, Van Nostrand Reinhold, New York.

Davidovits, Joseph, Douglas C. Comrie, and John H. Paterson, 1990, Concrete International: Design and Construction, Vol 12, No. 7, pp. 30-39.

Day, D. E., Z. Wu, and C. Ray, 1995, Chemically Durable Glasses For Vitrifying Phosphate Containing Simulated Nuclear Wastes, Final Report of PNL Contract No. 276822-A-F1.

DeLaguna, L. R., T. Tamura, H. O. Weeren, E. G. Stuxness, W. C. McClain, and R. C. Sexton, 1968, ORNL-4259, Oak Ridge National Laboratory.

Dicke, C. A., and R. W. Smith, 1993, Materials Research Society, Vol. 333, pp. 279-284.

Dole, L. R., G. C. Rogers, M. T. Morgan, D. P. Stinton, J. H. Kissler, S. M. Robinson and J. G. Moore, 1983, ORNL/TM-8579, Union Carbide.

Ebert, W. L., J. K Bates, and W. L. Bourcier, 1991, "The Hydration of Borosilicate Waste Glass in Liquid Water and Steam at $200^{\circ}$ C," Waste Management 11, p. 205.

Esh, David, and M. S. Thesis, 1994, The Pennsylvania State University.

Esh, David, and Barry E. Scheetz, 1995, Environmental Issuers and Waste Management Technologies in Ceramic and Nuclear Industries, Vol. 61, pp. 673-690. 
Fairhall, Graham A., and J. D. Palmer, 1987, Radioactive Waste Management and the Nuclear Fuel Cycle, Vol. 9, pp. 51-70.

Feng, X., 1988, "Composition Effects on Chemical Durability and Viscosity of Nuclear Waste Glasses Systematic Studies and Structural Thermodynamic Models," Ph. D. Dissertation, The Catholic University of America, Washington D.C.

Feng, X., 1994a, "Surface Layer Effects on Waste Glass Corrosion," Materials Research Society Symposium Proceedings, 333, p. 55.

Feng, X., G. Ordaz, and P. Krumrine, 1994b, "Glassy Slag - A Complementary Waste Form to Homogeneous Glass for Implementation of MAWS in Treating DOE Low-Level/Mixed Wastes," Spectrum'94, p. 1275.

Feng, X., 1994c, "Development of Vitreous Ceramics as Final Waste Forms for Mixed Wastes," Proceedings of Emerging Technologies in Hazardous Waste Management, Atlanta, GA, September 19-21, 1994, p. 235.

Feng, X., D. J. Wronkiwicz, N. R. Brown, M. Gong, C. Whitworth, K. Filius, and D. Battleson, 1994d, "Comparison of Glassy Slag Waste Form Produced in Laboratory Crucibles and in a Bench-Scale Plasma Furnace," Proceedings of Emerging Technologies in Hazardous Waste Management, Atlanta, GA, September 19-21, 1994, p. 872.

Feng, X., W. K. Hahn, W. Gong, L. Wang, and R. C. Ewing, 1995, Minimum Additive Waste Stabilization Using Vitreous Ceramics, Pacific Northwest National Laboratory, PNL-10826, September 1995, Richland, WA.

Feng, X., P. R. Hrma, J. H. Westsik, Jr., N. R. Brown, M. J. Schweiger, H. Li, J. D. Vienna, G. Chen, G. F. Piepel, D. E. Smith, B. P. McGrail, S. E. Palmer, D. Kim, Y. Peng, W. K. Hahn, A. J. Bakel, W. L. Ebert, D. K. Peeler, C. Chang, 1996a, Glass Optimization for Vitrification of Hanford Site Low-level Tank Waste, Pacific Northwest National Laboratory, PNL-10918, March 1996, Richland, Washington.

Feng, X., J. E. Surma, C. G. Whitworth, R. C. Eschenbach, and G. L. Leatherman, 1996b, "A Plasma Arc-Vitreous Ceramic Process for Hazardous and Radioactive Waste Stabilization," Glass as a Waste Form and Vitrification Technology: An International Workshop, National Research Council, Washington D.C. May 13-15, 1996, pp. 61-62.

Feng, X., M. J. Schweiger, H. Li, and M. Gong, 1996c, "Retention of Sulfur, Phosphorus, Chlorine, and Fluorine in Hanford Phase II Vendor LLW Glasses," Spectrum'96.

Fissile Materials Disposition Program, Screening of Alternative Immobilization Candidates for Disposition of Surplus Fissile Materials, February 1996, Lawrence Livermore National Laboratory, UCRL-ID-118819/L-20790-1, Livermore, CA 
Fu, S. S., K. S. Matlack, R. K. Mohr, M. Brandys, H. Hojaji, S. Bennett, J. Ruller, and I. L. Pegg, 1994, Development and Testing of the Minimum Additive Waste Stabilization (MAWS) System for Fernald Wastes, GTS Duratek, Inc. and Vitreous State Laboratory of the Catholic University of America, DOE/CH-9504.

Glasser F. P., and J. Marr, 1984, British Ceramic Proc., Vol. 35, p. 419.

Glasser F. P., and J. Marr, 1985, $1 l$ Cemento, pp. 85-94.

Glasser, F. P., 1993, Chemistry and Microstructure of Solidified Wastes Forms, Lewis Publishers, Boca Raton, pp. 231-240.

Godbee, H. W., 1980, Nuclear Chemical Waste Management, Vol 1, No. 29.

Godfrey, M. F., 1990, Analytical Proceedings, 0144-557X, Vol. 27, No.12, pp. 341-342.

Gougar, M. L. D., Duane D. Siemer, and Barry E. Scheetz, 1996a, Materials Research Society, Vol. 412, pp. 395-402.

Gougar, M. L. D., Duane D. Siemer, and Barry E. Scheetz, 1996b, DOE Spent Nuclear Fuel \& Fissile Material Management, American Nuclear Society, pp. 359-366.

Grosskurth, K. P., 1991, Materials Research Society, Vol. 179, pp. 273-281.

Hamilton, M. A., R. D. Rodgers, R. Veeh, and M. Zolynski, 1996, Materials Research Society, Vol. 412, pp. $469-474$.

Harvego, L., and J. Schafer, 1996, Integrated Thermal and Nonthermal Treatment Technology and Subsystem Cost Sensitivity Analysis, Idaho National Engineering Laboratory, INEL-96/0291.

Heafield, W., and P. Barlow, 1998, Nuclear Energy, Vol. 27 No. 6, pp. 367-376.

Heikkinen, T., 1990, YJT-90-04, Voimayhtioeiden Ydinjaetetoimikunta, Helsinki, p. 66.

Heimann, R. B., 1988, AECL, Rinaiva, Manit pp. 554-560.

Hoffer, Jefferson, and M. S. Thesis, 1988, The Pennsylvania State University.

Hrma, P. R., G. F. Piepel, M. J. Schweiger, D. E. Smith, D. S. Kim, P. E. Redgate, J. D. Vienna, C. A. LoPresti, D. B. Simpson, D. K. Peeler, M. H. Langowski, 1994, Property/Composition Relationships for Hanford High-Level Waste Glasses Melting at $1150^{\circ} \mathrm{C}$, Pacific Northwest National Laboratory, PNL-10359, Richland, Washington.

IAEA, 1979, Draft International Standard Report, ISO/DIS-6961.

Ipatti, A., 1990, Nuclear Waste Commission of Finnish Power Companies, YJT-90-19 p. 58. 
Ipatti, A., 1993, Nuclear Waste Commission of Finnish Power Companies, YJT-93-03 p. 71.

ISO, "Soxhlet Chemical Durability Test," ISO/TC85/SC5/WG5/N37, Standard in progress.

J. L. Buelt, C. L. Timmerman, K. H. Oma, V. F. FitzPatrick, and J. G. Carter, 1987, In Situ Vitrification of Transuranic Waste: An Updated Systems Evaluation and Application Assessment, PNL-4800, Suppl. 1, Pacific Northwest Laboratory, Richland, Washington.

Jantzen, C. M., 1986, "Investigation of Lead-Iron-Phosphate Glass for SRP Waste," American Ceramic Society, Third International Symposium on Ceramics in Nuclear Waste Management, Chicago, IL.

Jardine, L. J., and M. J. Steidler, 1978, "A Review of Metal-Matrix Encapsulation of Solidified Radioactive High-Level Waste," Argonne National Laboratory, ANL-78-19.

Jiang, W., X. Wu, and D. M. Roy, 1993, Materials Research Society, Vol. 294, pp. 255-260.

Kim, D., D. K. Peeler, and P. Hrma, 1995, "Effects of Crystallization on the Chemical Durability of Simulated Nuclear Waste Glasses," Ceramic Transactions 61, p. 177.

Knauss, K. G., W. L. Bourcier, K. D. McKeegan, C. I. Merzbacher, S. N. Nguyen, F. J. Ryerson, D. K. Smith, H. C. Weed, and L. Newton, 1990, "Dissolution Kinetics of a Simple Analogue Nuclear Waste Glass as a Function of $\mathrm{pH}$, Time, and Temperature," Mat. Res. Symposium Proceedings 176, p. 371 .

Kumar, A., M. S., 1982, Thesis, The Pennsylvania State University.

Kumar, A., Ph.D., 1985, Thesis, The Pennsylvania State University.

Lamberger, P. H., and M. L. Rodgers, 1980, MLM-2784, Mound Facility, p. 30.

Lamberger, P. H., and M. L. Rodgers, 1981, MLM-2844, Mound Facility, p. 18.

Lamberger, P. H., and M. L. Rodgers, 1982, MLM-3048, Mound Facility, p. 19.

Lamberger, P. H., and M. L. Rodgers, 1983a, MLM-3102, Mound Facility, p. 24.

Lamberger, P. H., and M. L. Rodgers, 1983b, MLM-3128, Mound Facility, p. 26.

Langton, C. A., M. D. Dukes, and R.V. Simmons, 1983, Materials Research Society, Vol. 15.

Lee. J. H., Ph.D. 1993, Thesis, The Pennsylvania State University.

Lee, J. H., D. M. Roy, and B. E. Scheetz, 1994, NTIS Workshop on Research Results on Performance and Modeling of Concrete as an Engineered Barrier for LLW Disposal. 
Li, H., J. G. Darab, P. A. Smith, X. Feng, and D. K. Peeler, 1995, "Chemical Durability of Low-Level Simulated Nuclear Waste Glasses with High-Concentrations of Minor Components," Proceedings of the 36th Annual Meeting of the Institute of Nuclear Materials Management, Palm Desert, CA, July 9-12, p. 460.

Li, H., J. G. Darab, P. A. Smith, M. J. Schweiger, D. E. Smith, and P. Hrma, 1995, "Effect of Minor Components on Vitrification of Low-level Simulated Nuclear Waste Glasses," Proceedings of the 36th Annual Meeting of the Institute of Nuclear Materials Management, Palm Desert, CA, July 9-12, p. 466.

Li, H., et al., 1996 Fall Meeting, "Compositional Effects on Precipitation of Nepheline in Glass and Its Impact on Resistance of High-Level Waste Glasses Against Corrosion by Water," Submitted for Materials Research Society.

Li, H., J. D. Vienna, P. Hrma, M. J. Schweiger, D. E. Smith, and M. Gong, 1996, "Borosilicate Based Glasses for Immobilization of Plutonium-Bearing Materials," Ceramic Transactions, 30.

Libert, Marie F., R. Sellier, G. Jouquet, M. Trescinski, and H. Spor, 1993, Materials Research Society, Vol. 294, pp. 267-272.

Lokken, R. O., L. A. Chick, and L. E. Thomas, 1982, "Development and Characterization of Basalt Glass Ceramics for the Immobilization of Transuranic Wastes," Pacific Northwest National Laboratory, PNL-4136.

Malek, R. I. A., and D. M. Roy, 1983, 6th International Conference on Alkalis in Concretes, Danish Concrete Association.

Mayberry, J. L. et al., 1993, Technical Area Status Report for Low-Level Mixed Waste Final Waste Forms, Volumes I and II, DOE/MWIP-3, August.

McDaniel, E. W., and D. B. Delzer, 1988, Radioactive Waste Forms for the Future, Elsevier Science, pp. 565-587.

McLellan, G. W., and E. B. Shade, 1984, Glass Engineering Handbook, 3rd Edition, McGraw-Hill Book Company, New York, New York.

Moore, J. G., 1981, Oak Ridge National Laboratory, CONF-8005107, pp. 194-216.

Muraoka, S., Susumu, Y. Murase, Yoshinobu, Yamada, Kiyotsugu, 1983, JAERI-M-83-004, Japan Atomic Energy.

Muraoka, S., H. Nakamura, Y. Murase, 1985, JAERI-M-85-097, Japan Atomic Energy.

Palmer, John D., 1990, Nuclear Waste Management, American Ceramic Society., Vol. 9, pp. 137-150.

Palmer, John D., and Graham A. Fairhall, 1993, Materials Research Society, Vol. 294, pp. 285-290. 
Pegg, I. L., P. B. Macedo, J. K. Bates, C. H. Peterson, 1990, "A Proposed ASTM Standard Practice for The Prediction of Long-Term Behavior of Waste Package Materials in a Geologic Repository," Waste Management'90, Tucson, Arizona, 1990, Vol. 2, p. 829.

Pegg, I. L., 1994, "Development of the Minimum Additive Waste Stabilization (MAWS) Program for Fernald," Ceramic Transactions, 39, p. 13.

Peterson, M. E., T. D. Powell, and C. L. Timmerman, 1992, Engineering-Scale In Situ Vitrification of Simulated Oak Ridge National Laboratory Liquid Waste Seepage Trench, PNL-7988, Pacific Northwest Laboratory, Richland, WA.

Pihlajavaara, S.E., and E. Pihlman, 1983, VTT-TUTK-146 Valton Tecknillinene Tutkimuskeskus, Finland, pp. 51-61.

Plecas, I. B., J.D. Drljaca, and A.M. Kostadinovic, 1987, Waste management ‘87, pp. 503-506.

Post, R. G. , 1981, Exxon Nuclear Idaho Company, ENICO-1088.

Reimann, G. A., J. D. Grandy, T. L. Eddy, and G. L. Anderson, 1992, Summary of INEL Research on the Iron-Enriched Basalt Waste Form, Idaho National Engineering Laboratory, EGG-WTD-10056.

Rodgers, R. D., M. A. Hamilton, R. H. Veeh, and J. W. McConnell, 1996, Materials Research Society, Vol. 412, pp. 475-482.

Rogers, Robert, D., Melinda A. Hamilton, and John W. McConnell, 1993, Materials Research Society, Vol. 294, pp. 261-266.

Rogers, Robert, D., Melinda A. Hamilton, and John W. McConnell, 1993a, Microbial Influenced Cement Degradation Literature Review, NUREG/CR 5987, EGG-2695, Idaho National Engineering Laboratory, Idaho Falls, ID.

Roy, D. M., B. E. Scheetz, L. D. Wakeley, and S. D. Atkinson, 1980, DOE/ET/41900-1 Rockwell International, Energy Systems Group.

Roy, D. M., B. E. Scheetz, L. D. Wakeley, and M. W. Barnes, 1982, Nuclear and Chemical Waste Management, Vol. 3, pp. 35-42.

Roy, D. M., A. Kumar, and J. P. Rhodes, 1986, ACI SP-91, American Concrete Institute, pp. 1423-1444.

Roy, D. M., 1990, "Cementitious Materials in Nuclear Waste Management," Cement Research Progress 1988, American Ceramic Society.

Roy, D. M., and M. R. Silsbee, 1991, Materials Research Society, Vol. 245, pp. 153-164. 
Roy, D. M., and Barry E. Scheetz, 1993, Chemistry and Microstructure of Solidified Wastes Forms, Lewis Publishers, Boca Raton, pp. 83-102.

Rushbrook, P. E., 1985, AERE-R-11408 UKAEA Atomic Research Establishment, Harwell.

Sand, Wolfgang, Eberhard Brock, and David C. White, 1984, Corrosion/84.

Scheetz, B. E., D. M. Roy, C. Tanner, and M. W. Barnes, 1985, Bulletin of the American Ceramic Society, Vol. 64, No. 5, p. 687-690.

Scheetz, Barry E., and Jefferson Hoffer, 1996, ACI SP-158, American Concrete Institute.

Schulz, W. W., et al., 1980, Preliminary Evaluation of Alternative Forms for Immobilization of Hanford High-Level Defense Wastes, Rockwell International, RHO-ST-32, Richland, WA.

Serne, R. J., W. J. Martin, R. D. Lokken, V. L. LeGore, C. W. Lindenmeier, and P. F. C. Martin, 1989, PNL-6960, Battelle Pacific Northwest Laboratory.

Serne, R. J., D. Rai, P. F. Martin, A. R. Felmy, L. Rao, and S. Ueta, 1996, Materials Research Society, Vol. 412, pp. 459-468.

Shade, J. W., and G. F. Piepel, 1990, Viscosity, Electrical Conductivity, and Cesium Volatility of ORNL Vitrified Soils with Limestone and Sodium Additives, PNL-7331, Pacific Northwest Laboratory, Richland, WA.

Shropshire, D., M. Sherick, and C. Biagi, 1995, Waste Management Facilities Cost Information for Mixed Low-Level Waste, Idaho National Engineering Laboratory, INEL-95/0014.

Siemer, Darryl D., Barry E. Scheetz, and Mary Lou D. Gougar, Materials Research Society, Vol. 412, pp. 403-418.

Silsbee, M. R., and B. E. Scheetz, 1996, Annual Report to PQ, Corp.

Snyder, K. A., J. R. Clifton, and J. Pommersheim, 1996, Materials Research Society, Vol. 412, pp. 491-498.

Stinton, D. P., E. W. McDaniel, and H. W. Heeren, 1984, Materials Research Society, Vol. 7.

Tallent, O. K., E. W. McDaniel, G. D. Del Cul, K. E. Dodson, and D. R. Trotter, 1988, Materials Research Society, Vol. 112, pp. 23-30.

Test Results of Screening High-Metal-Content Wastes in a Plasma Centrifugal Furnace Under the Minimum Additive Waste Stabilization Program, 1994, Volume 1, MSE, Inc., PTP-3, Butte, Montana. 
Timmons, D. M., and L. E. Thompson, 1996, "Geochemical and Petrographic Studies and the Relationships to Durability and Leach Resistance of Vitrified Products From the In Situ Vitrification Process," Spectrum'96, August 18-23, 1996, Seattle, WA..

Tixier, J. S., and B. P. Spalding, 1994, "Development of In Situ Vitrification For Remediation of ORNL Contaminated Soils," Spectrum'94, p. 1668.

U.S. DOE, 1981, "Nuclear Waste Materials Handbook (Test Methods)," DOE/TIC-11400.

U.S. EPA, "Toxicity Characteristic Leaching Procedure Method," 40 CFR 261, App. II; also SW-846.

U.S. NRC, 1991,"Technical Position on Waste Form" (Rev. 1), U.S. Nuclear Regulatory Commission, Office of Nuclear Material Safety and Safeguards, Low-Level Waste Management Branch Division of Low-Level Waste Management, Washington, D. C., January.

Vinjamuri, K., 1993, "Talc-Silicon Glass-Ceramic Waste Forms for Immobilization of High-Level Calcined Waste," WINCO-1229, Westinghouse Idaho Nuclear Company,

Vitreous State Laboratory, 1996, "VSL Glass Leach Testing Inventory Report," The Catholic University of America, Washington DC, in preparation.

Volf, M. B., 1984, Chemical Approach to Glass, New York: Elsevier Science.

Walton, J. C., L. E. Plansky, and R. W. Smith, 1990, Models for Estimation of Service Life of Concrete Barriers in Low-Level Radioactive Waste Disposal, NUREG/CR-5542, EGG-2597, Idaho Falls, ID.

Weeren, H. O., 1977, Nuclear Engineering Design, Vol 44, pp. 291-300.

Weerenm, H. O., J. G. Moore, and E. W. McDaniel, 1979, Materials Research Society, Vol. 1, pp. 257-264.

Wierig, H. J., 1983, VGB Kraftwerkstech, Vol. 63:8, pp. 721-728.

Wilhite, E. L., C. A. Langton, H. F. Sturm, R. L. Hooken, and E. S. Occhipirti, 1988, Spectrum 88, American Nuclear Society, pp. 99-101.

Wilson, Alan D., and John W. Nickholson, 1993, Acid-base Cements, Cambridge University Press.

Wilson, C. N., editor, 1996, Evaluation of Melter Technologies for Vitrification of Hanford Site Low-Level Tank Waste-Phase I Testing Summary Report, Westinghouse Hanford Company, WHC-SD-WM-ER-498, Richland, WA.

Young, L., Fred E. Causey, Phillip G. Malone, Wm. N, Barbston, 1995, U.S. Patent 5,411,653.

Yuanfang, L., H. R. von Guntern, 1988, NAGRA-NTB-88-29, Nationale Genossenschaft fuer die Lagerung Radioaktiver Abfaelle, Switzerland, p. 183. 